Historic, archived document

Do not assume content reflects current scientific knowledge, policies, or practices. 

aSD 11

\section{A35 \\ cop. 2 \\ ites \\ e}

\section{Forest}

Service

North Central

Forest Experiment

Station

Resaurce

Rosearch

Bulletin NC-84

USS
Timber Resource of Wisconsin's Central Survey Unit, 1983

Jerold T. Hahn

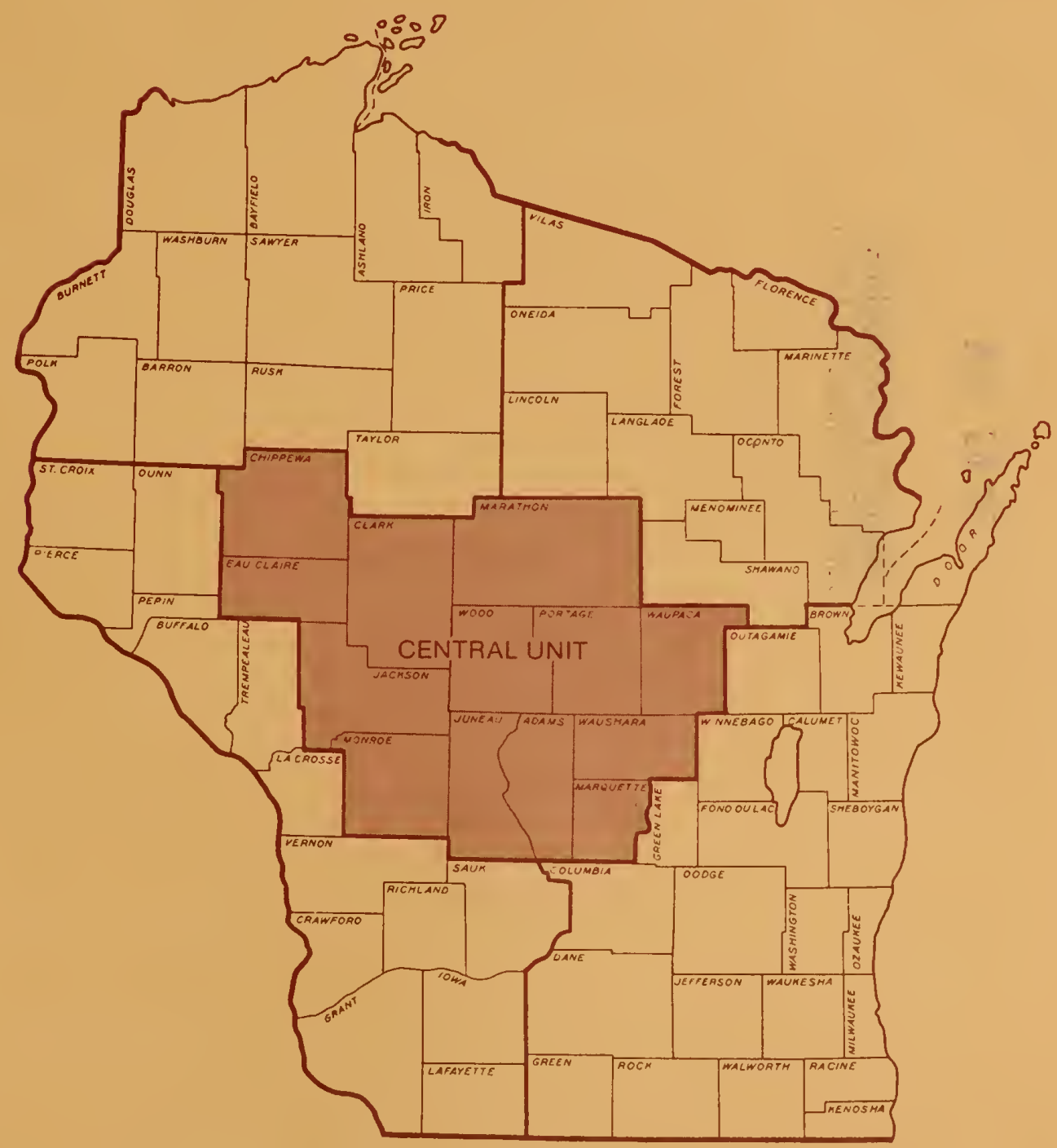


Information contained in this report includes the most commonly used Forest Inventory and Analysis statistics. However, additional forest resource data can be provided to interested users. Persons requesting additional information that can be provided from the raw inventory data are expected to pay for the retrieval costs. These costs will vary depending on the complexity of the request, from less than $\$ 100$ for a relatively simple request to $\$ 2,000$ for a complex retrieval involving the services of a Forest Inventory and Analysis computer programmer. If requests for data conflict with ongoing Forest Inventory and Analysis work, they will be scheduled so as to minimize the impact on the work unit.

Requests for unpublished information may be directed to:

Burton L. Essex

Forest Inventory and Analysis Project

North Central Forest Experiment Station

1992 Folwell Avenue

St. Paul, Minnesota 55108

Phone: (612) 642-5282

Area served: Illinois, Indiana, Iowa, Kansas, Michigan, Minnesota, Missouri, Nebraska, North Dakota, eastern South Dakota, Wisconsin.

North Central Forest Experiment Station

Forest Service--U. S. Department of Agriculture

1992 Folwell Avenue

St. Paul, Minnesota 55108

Manuscript approved for publication October 28, 1984 


\section{FOREWORD}

Forest Inventory and Analysis (FIA) is a continuing endeavor as mandated by the Renewable Forest and Rangeland Resources Planning Act of 1974 . Prior inventories were mandated by the McSweeney-McNary Forest Research Act of 1928. The objective of FIA is to periodically inventory the Nation's forest land to determine its extent, condition, and volume of timber, growth, and depletions. Up-to-date resource information is essential to frame intelligent forest policies and programs. USDA Forest Service regional experiment stations are responsible for conducting these inventories and publishing summary reports for individual States. The North Central Forest Experiment Station is responsible for forest resource evaluation in Illinois, Indiana, Iowa, Kansas, Michigan, Minnesota, Missouri, Nebraska, North Dakota, eastern South Dakota, and Wisconsin.

Fieldwork for the Wisconsin Statewide forest inventory was begun in the summer of 1981 and completed in late 1983. Reports on the three previous inventories of Wisconsin's timber resource are dated 1936, 1956, and 1968.

More accurate survey information was obtained during the 1983 survey than otherwise would have been feasible because of intensified field sampling. Such sampling was made possible by additional funding and field personnel provided the North Central Station by the Wisconsin State Legislature through the Department of Natural Resources. Data from the Departments' canvass of all primary wood-using plants in the State was used to help estimate the quantity of timber products harvested in Wisconsin.

Aerial photos used in the Central Unit Forest Inventory were furnished by the Wisconsin Department of Natural Resources and the USDA Agricultural Stabilization and Conservation Service. 


\section{CONTENTS}

Highlights Page

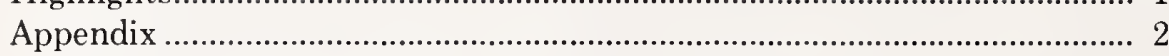

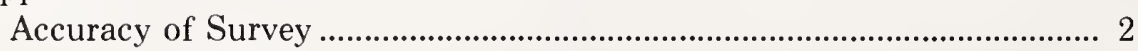

Survey Procedures................................................................................. 3

Comparing Wisconsin's Fourth Inventory With the Third Inventory.. 4

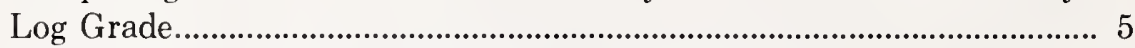

Tree Species Groups in Wisconsin's Central Unit................................. 9

Metric Equivalents of Units Used in this Report............................... 9

Definition of Terms .................................................................................. 10

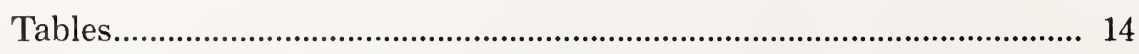




\title{
TIMBER RESOURCE OF WISCONSIN'S CENTRAL SURVEY UNIT, 1983
}

\author{
Jerold T. Hahn, Principal Mensurationist
}

\section{HIGHLIGHTS}

\section{Forest Area}

- Forest land accounted for 3.0 million acres (42 percent of the Unit's land area) in 1983, this constitutes a 5.1 percent increase since 1968 .

- Commercial forest land occupied 2.95 million acres in 1983--an increase of 4.2 percent from the 2.83 million acres in 1968.

- Productive-reserved forest land totaled 30,100 acres in 1983, compared to 3,900 acres in 1968. Major additions since 1968 include an increase in the number and area of State and county parks (14,200 acres in 1983), scientific and natural areas, military reservation impact areas, and Christmas tree plantations (11,000 acres).

- Jackson County contained the largest area of commercial forest in 1983 (371,400 acres); in 1968 it had 345,500 acres.

- Farmers and miscellaneous private owners continued to hold 74 percent of the commercial forest (2.1 million acres in 1968 and 2.2 million acres in 1983). A new definition of farm ownership shifted much of what was previously in the farmer category to the miscellaneous private category.

- County and municipal agencies owned 399,300 acres of commercial forest in 1983 (14 percent).

- The oak-hickory forest type continued to dominate the commercial forest land base in 1983, comprising 32 percent $(937,600$ acres $)$ of the commercial forest area.

- The maple-birch type increased 30 percent to 506,200 acres while the aspen type decreased 16 percent to 577,500 acres.

- Sapling and seedling stands occupied 30 percent of the commercial forest in 1983 , compared to 38 percent in 1968.

- Sawtimber stands, which increased by 330,700 acres between surveys, amounted to 30 percent of the commercial forest in 1983, compared to 19 percent in 1968.
- Sixty-four percent ( 114,900 acres) of the commercial plantation area is in the red pine type. This is 85 percent of the total area $(135,000$ acres $)$ in red pine.

- Sixty-five percent (116,800 acres) of the plantations are less than 30 years old.

- Ten percent of all commercial forest area has white pine as prominent conifer in the understory, and 8 percent has jack pine as prominent conifer in the understory.

- Less than 2 percent of all forest land is unproductive or reserved.

- The average site index for commercial forest land in the Unit is 64 feet at age 50 .

\section{Timber Volume}

- The volume of growing stock in 1983 was 2.87 billion cubic feet, 75 percent greater than the 1.64 billion in 1968.

- Sawtimber volume amounted to 6.3 billion board feet in 1983, 94 percent greater than the 1968 volume (3.2 billion board feet).

- The 2.2 billion cubic feet of hardwoods make up 75 percent of the growing-stock volume.

- Red pine growing-stock volume increased 609 percent since 1968. Ingrowth of plantations to merchantable size was the dominant factor in this dramatic increase. Area of red pine sawtimber increased from 7,500 acres to 20,900 acres, and red pine poletimber increased from 20,100 acres to 77,100 acres.

- The oaks (814 million cubic feet), aspens (505 million), and pines (595 million) contain the highest volumes, and together account for nearly 67 percent of the growing-stock volume.

- Average growing-stock volume per acre in 1983 was 972 cubic feet, compared to 580 cubic feet in 1968.

- Forty-five percent of the growing-stock volume is in stands from 31- to 60-years old.

- More than half of the sawtimber volume is in trees with grade 3 butt logs. Tree diameter is generally the limiting criterion. 
- The volume in cull trees (rough, rotten, and short$\log$ cull) is 528 million cubic feet; salvable dead tree volume is 45 million cubic feet.

\section{Stand Conditions}

- Net annual growth on growing-stock trees was 100 million cubic feet in 1982.

- The net annual growth rate of growing stock was 3.5 percent of inventory in 1982.

- Net growth averaged 33.9 cubic feet per acre in 1982.

- Annual mortality of growing stock amounted to 24.2 million cubic feet (0.8 percent of inventory) in 1982 .

- Disease accounted for 23 percent of the mortality in 1982, chiefly diseases of aspen and elm.

- Elm mortality resulted in a 57 percent decline in elm volume between inventories, chiefly due to the effects of Dutch elm disease.

\section{Timber Use}

- Timber removals from growing stock in 1982 totaled over 48 million cubic feet ( 1.7 percent of inventory), compared to 42 million cubic feet (2.6 percent of inventory) in 1967.

- The pines made up 26 percent of the 1982 removals volume, although they account for only 21 percent of the growing-stock volume.

- Output of roundwood products from growing stock totaled 43.3 million cubic feet in 1981; 47 percent was pulpwood, 14 percent was fuelwood, and 37 percent was saw logs.

- Wood residue from primary plants totaled 8.6 million cubic feet in 1981, 97 percent of which was used.

\section{Biomass}

- Highest yields of live tree biomass are in the northern white cedar ( 82 green tons per acre), the white pine (82 tons), and the red pine (78 tons) forest types.

- Live tree biomass (trees greater than 1 inch d.b.h.) totaled 193 million green tons (65 tons per acre) in 1983 , with just under half in the boles of growingstock trees.

\section{APPENDIX}

\section{ACCURACY OF SURVEY}

Forest inventory and Analysis information is based on a sampling procedure designed to provide reliable statistics at the State and Unit levels. Consequently, the reported figures are estimates only. A measure of reliability of these figures is given by sampling errors. These sampling errors mean that the chances are two out of three that if a 100-percent inventory had been taken, using the same methods, the results would have been within the limits indicated.

For example, the estimated growing-stock volume in the Central Unit in 1983, 2,868.9 million cubic feet, has a sampling error of \pm 2.72 percent $( \pm 78.0$ million cubic feet). The growing-stock volume from a 100-percent inventory would be expected to fall between $2,946.9$ and 2,790.9 million cubic feet $(2,868.9 \pm 78.0)$, there being a one in three chance that this is not the case.
The following tabulation shows the sampling errors for the 1983 Central Unit Forest Inventory:

\begin{tabular}{|c|c|c|}
\hline Item & Unit totals & $\begin{array}{c}\text { Sampling } \\
\text { error }\end{array}$ \\
\hline Growing stock & (Million cubic feet) & (Percent) \\
\hline Volume & $2,868.9$ & 2.72 \\
\hline Growth & 100.2 & 3.73 \\
\hline Removals & 48.2 & 26.52 \\
\hline Sawtimber & (Million board feet ${ }^{1}$ ) & \\
\hline Volume & $6,295.7$ & 3.92 \\
\hline Growth & 267.7 & 4.86 \\
\hline Removals & 148.4 & 27.36 \\
\hline Commercial & (Thousand acres) & \\
\hline forest land & $2,950.9$ & 0.35 \\
\hline
\end{tabular}

As survey data are broken down into sections smaller than Survey Unit totals, the sampling error increases. For example, the sampling error for growing-stock volume in a particular county is higher than that for total growing-stock volume in the Unit (table 66 shows the sampling errors for estimates smaller than Unit totals).

${ }^{1}$ International 1/4-inch rule. 


\section{SURVEY PROCEDURES}

We used a two-phase sampling design for the 1983 Wisconsin survey. This sampling scheme and associated estimators are similar to sampling with partial replacement (SPR) in that a set of randomly located plots was available for remeasurement and a set of new randomly located plots was established and measured. Major enhancements in the new Wisconsin design were stratification for disturbance on the old sample and use of a growth model to improve regression estimates made on the old undisturbed forest plots. The growth model used was the Stand and Tree Evaluation and Modeling System (STEMS).'

The major steps in the new survey design were as follows:

1. The first phase of the survey was to interpret aerial photos. In this phase two sets of random points were located on current aerial photographs. The first was a set of new photo points and the second was a set of relocated old photo points (ground plot locations from the previous inventory). A total of 41,492 1-acre points, including old ground sample locations, was systematically distributed across aerial photos of the entire Unit. These points were classified into land classes as shown below to make a preliminary estimate of forest area. Next, 19,278 of these points were stereoclassified as to stand-size class and density. Finally, 3,195 points were examined on the ground to correct the preliminary area estimate for errors in classification and for actual changes in land use since the photos were taken.

\begin{tabular}{|c|c|c|c|}
\hline Land class & $\begin{array}{l}\text { Photo points } \\
\text { classified }\end{array}$ & $\begin{array}{l}\text { Photo points } \\
\text { stereoclassified }\end{array}$ & $\begin{array}{l}\text { Inventory } \\
\text { plots checked }\end{array}$ \\
\hline Forest land & 18,363 & 18,363 & 1,372 \\
\hline $\begin{array}{l}\text { Unproductive/ } \\
\text { reserved forest }\end{array}$ & & & \\
\hline land & 134 & 134 & 16 \\
\hline Nonforest land & & & \\
\hline with trees & 781 & 781 & 48 \\
\hline without trees & 21,535 & 0 & 1,704 \\
\hline Water & 679 & 0 & 55 \\
\hline Total & $\overline{41,492}$ & $\overline{19,278}$ & $\overline{3,195}$ \\
\hline
\end{tabular}

2. The second phase of the survey was to sample ground plots. The plot selection and measurement procedures of phase two of the new Wisconsin survey design are outlined in figure 1.

"For more information on STEMS, see: Belcher, D. L.; Holdaway, M.R.; Brand, G.J. A description of STEMS: The stand and tree evaluation and modeling system. Gen. Tech. Rep. NC-79. St. Paul, MN: U.S. Department of Agriculture, Forest Service, North Central Forest Experiment Station; 1981. 18 p.
From the new photo points, a random sample of ground plots was established and land use, volume, mortality, and cutting were recorded. At each forest ground plot location, variable-radius plots (basal area factor 37.5) were established at 10 points uniformly placed over the sample acre. These locations were monumented for future remeasurement.

On the old inventory photo points (old plot locations), we used a somewhat different procedure. Old plots were either remeasurable (monumented) or nonremeasurable (not monumented and thus difficult to relocate). Within both of these groups, old plots were additionally identified as undisturbed or disturbed. The remeasurable old inventory photo points classified as forest undisturbed were remeasured on the ground to obtain current land use, volume, growth, and removals data. Additionally, all forest undisturbed remeasurable plots were projected to the current time using STEMS to provide estimates of current volume and growth. The comparison of projected and observed values on these plots provided regression estimators to adjust the projected values of the undisturbed nonremeasurable plots. All disturbed remeasurable plots were remeasured on the ground to assess changes since the last inventory.

Disturbance as used here refers to any change on a plot that can be detected on aerial photos and that the STEMS growth processor cannot predict, such as catastrophic mortality, cutting, seedling stands, and land use change.

The nonremeasurable forest points are those that were not monumented during the 1968 inventory but

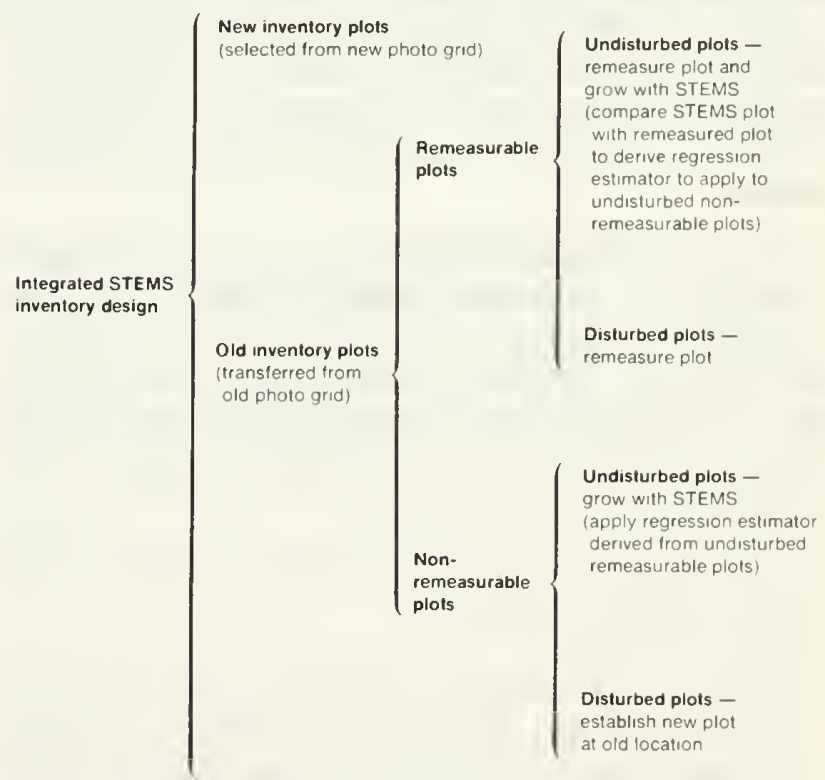

Figure 1.--Logic structure for the 1983 Wisconsin sample design. 
played a crucial role in the new survey design. The nonremeasurable undisturbed forest points were visited on the ground at the time of the last survey and following careful examination of both past and current photographs it was determined that nothing happened that STEMS was unable to simulate. STEMS was then used to update the old plot and tree data to produce an estimate of current data. Thus these points became ground plots even though the information was obtained without actually visiting the plot. The plot record for each updated plot was sent to the field for verification of current ownership information. For points classified as disturbed, a new ground plot was established as close to the old location as possible. This allowed information about land use trends to be recorded even though the old plot could not be exactly relocated for remeasurement.

The estimation procedure for computing statistics from this sampling design was more complicated than the simple two-phase estimation procedure used in the past. In fact, this procedure yielded two independent samples, one coming from the new photo points and the other coming from the old photo points that were remeasured or projected. A more detailed description of the sampling design is available in a separate publication. ${ }^{3}$

3. Statistics on timber utilization during 1981 were obtained from mill surveys. The Wisconsin Department of Natural Resources canvassed resident sawmills, veneer mills, and other primary wood-using plants. The North Central Forest Experiment Station canvassed out-of-State sawmills, pulpmills, and veneer mills to determine their use of Wisconsin timber. Fuelwood and fencepost output was based on a sample of public and private landowners to determine their production of fuelwood and fenceposts. Estimates of primary mill residue used for fuelwood were obtained from the canvass of Wisconsin primary wood-using plants.

4. A total of 2,568 felled trees on 133 active logging operations was measured throughout the State during 1981-1982 to develop wood utilization factors for converting timber products output to timber removals for saw logs and pulpwood. Factors for all other products were obtained during the 1966-1967 Wisconsin utilization study.

5. Field data were sent to St. Paul, Minnesota, to be processed and analyzed.

"Hahn, J. T.; Hansen, M. H.; Fairweather, S. E. A Sampling procedure incorporating a growth simulator. U.S. Department of Agriculture, Forest Service, North Central Forest Experiment Station. St. Paul, MN 55108.1984 (Manuscript in process).

\section{COMPARING WISCONSIN'S FOURTH INVENTORY WITH THE THIRD INVENTORY}

Data from new forest inventories are often compared with data from earlier inventories to determine trends in forest resources. However, changes in procedures and definitions between surveys often make it necessary to adjust earlier survey data so that they are comparable to data from the new survey. A consistency check will be made for each Forest Unit in Wisconsin to ensure that the changes observed between inventories reflect actual changes in the resource and not changes in definitions or procedures.

\section{Identifying and Correcting Procedural Changes}

Between the 1968 and 1983 inventories of Central Wisconsin, some procedural changes were made in the method of deriving annual mortality estimates and determining forest type; revised volume equations were used.

Mortality figures for the 1968 inventory were based on field estimates from nonremeasurement plots. Information gathered on remeasurement plots during the current inventory was used to adjust the 1968 mortality figures. This adjustment also changed the estimate of net growth for the 1968 inventory. Additionally, the old spruce-fir forest type was separated into two distinct types for the new industry-white spruce and balsam fir. Comparisons with old data may be made by adding the two new types together.

The difference in volume equations resulted in a 6percent increase in reported growing-stock volume for 1968.

\section{Checking for Consistency}

A test was made to ensure that it was possible to move from the adjusted 1968 resource statistics to the 1983 values by means of Timber Resource Analysis System (TRAS), a USDA Forest Service computer program for updating, backdating, and projecting timber volume, growth, mortality, and removals. Using the adjusted 1968 numbers of softwood and hardwood trees by 2 -inch diameter class and applying 1983 cubic feet per tree estimates, volumes were generated for the 1968 inventory that are comparable with 1983 volumes. Then, using growth rates, mortality rates, and removals rates for the period between the two surveys, TRAS projected the inventory from 1968 to 1983 . The program prints out volumes by diameter class for softwoods and hardwoods for selected years in the period. 
Thus, inconsistencies in volume, growth, mortality, and removals were identified and resolved.

TRAS generates an estimate of what total removals had to be for the inventory to have changed as it did between surveys, given the volume, growth, and mortality data. Estimates of removals for products and for logging residues, two of the three components of total timber removals, were available from an independent utilization study. An estimate of "other" removals (see Definition of Terms in Appendix), the third component of total removals, was made by subtracing the first two removals components from the TRAS-generated total removals estimate. This estimate of "other" removals was compared with findings from remeasurement plots and new plots (stump counts and land use change) to check its validity. When necessary, TRAS was rerun and adjusted until other removals were compatible with the estimate from field data. Total removals were "trend level removals" because the estimate of "other" removals was based on a removals trend line from 1968 to 1983.

\section{LOG GRADE}

In Wisconsin's Central Unit the butt log of every sawtimber tree on every full permanent sample plot was graded for quality.

Butt logs were graded on the basis of external characteristics as indicators of quality. Hardwood species were graded according to "Hardwood Log Grades for Standard Lumber." ${ }^{4}$ The best 12 -foot section of the lowest 16 -foot hardwood log, or the best 12 -foot upper section if the butt log did not meet minimum log-grade standards, was graded as follows:

'Vaughn, C. L.; Wollin, C. A.; McDonald, K. A.; Bulgrin, E. H. Hardwood log grades for standard lumber. Res. Pap. FPL 63. Madison, WI: U.S. Department of Agriculture, Forest Service, Forest Products Laboratory; $1966.52 p$. 


\section{Forest Service standard grades for hardwood factory saw logs}

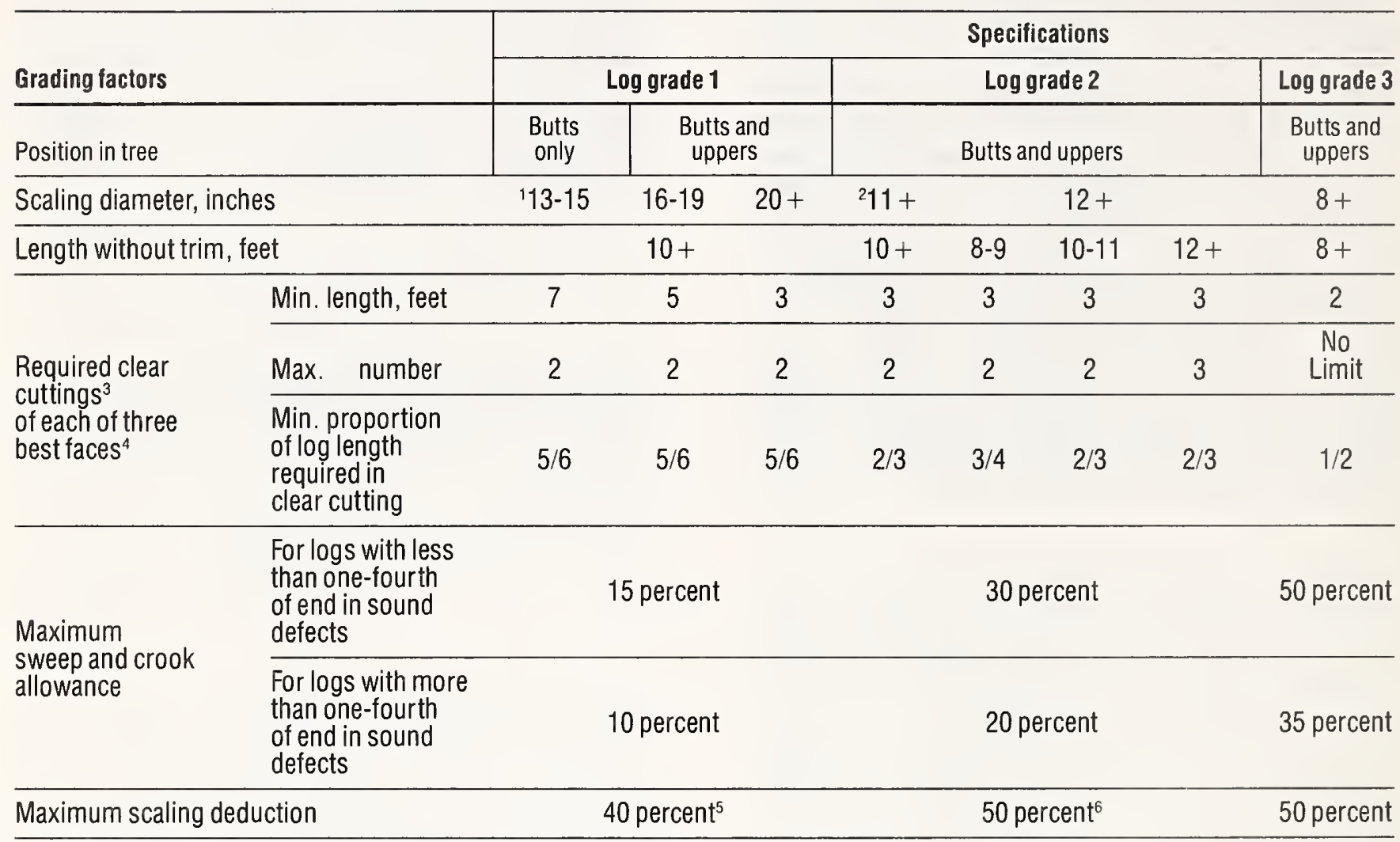

'Ash and basswood butts can be 12 inches if they otherwise meet requirements for small \#1's.

${ }^{2} T e n-i n c h$ logs of all species can be \#2 if they otherwise meet requirements for small \#1's.

${ }^{3} \mathrm{~A}$ clear cutting is a portion of a face, extending the width of the face, that is free of defects.

${ }^{4} \mathrm{~A}$ face is one-fourth of the surface of the $\log$ as divided lengthwise.

${ }^{5}$ Otherwise \# 1 logs with 41-60 percent deductions can be \#2.

${ }^{\circ} 0$ therwise \#2 logs with 51-60 percent deductions can be \#3. 


\section{Forest Service standard specifications for hardwood construction logs (tie and timber logs) ${ }^{1}$}

\begin{tabular}{|c|c|c|}
\hline \multicolumn{2}{|l|}{ Position in tree } & Butt and upper \\
\hline \multicolumn{2}{|l|}{ Min. diameter, small end } & 8 inches + \\
\hline \multicolumn{2}{|l|}{ Min. length, without trim } & 8 feet \\
\hline \multicolumn{2}{|l|}{ Clear cuttings } & No requirements. \\
\hline \multicolumn{2}{|l|}{ Sweep allowance, absolute } & $\begin{array}{l}\text { One-fourth of the diameter at the small end for each } 8 \text { feet of } \\
\text { length. }\end{array}$ \\
\hline \multirow{3}{*}{ Sound surface defects } & Single knots & $\begin{array}{l}\text { Any number, if no one knot has an average diameter above the } \\
\text { callus in excess of one-third of the log diameter at point of } \\
\text { occurrence. }\end{array}$ \\
\hline & Whorled knots & $\begin{array}{l}\text { Any number if sum of knot diameters above the callus does } \\
\text { not exceed one-third of the log diameter at point of } \\
\text { occurrence. }\end{array}$ \\
\hline & Holes & $\begin{array}{l}\text { Any number provided none has a diameter over one-third of } \\
\text { the log diameter at point of occurrence, and none extends } \\
\text { more than } 3 \text { inches into included timber. }\end{array}$ \\
\hline \multicolumn{2}{|l|}{ Unsound surface defects } & $\begin{array}{l}\text { Same requirements as for sound defects if they extend into } \\
\text { included timber. }{ }^{2} \text { No limit if they do not. }\end{array}$ \\
\hline & Sound & No requirements. \\
\hline End defects & Unsound & $\begin{array}{l}\text { None allowed; log must be sound internally, but will admit one } \\
\text { shake not to exceed one-fourth the scaling diameter and will } \\
\text { admit a longitudinal split not extending more than } 5 \text { inches } \\
\text { into the contained timber. }\end{array}$ \\
\hline
\end{tabular}

'These specifications are minimum for the class. If, from a group of logs, factory logs are selected first, thus leaving only nonfactory logs from which to select construction logs, then the quality range of the construction logs so selected is limited, and the class may be considered a grade. If selection for construction logs is given first priority, it may be necessary to subdivide the class into grades.

${ }^{2}$ Included timber is always square, and dimension is judged from small end.

Softwood species were graded according to the following specifications on the following page. 


\section{Log Grades for Eastern White Pine}

\begin{tabular}{|c|c|c|c|c|c|c|}
\hline $\begin{array}{l}\text { Log } \\
\text { grade }\end{array}$ & $\begin{array}{c}\text { Minimu } \\
\text { Diameter }\end{array}$ & $\begin{array}{l}\text { n size } \\
\text { Length' }\end{array}$ & $\begin{array}{l}\text { Sweep } \\
\text { or crook } \\
\text { allowance }\end{array}$ & $\begin{array}{l}\text { Total cull } \\
\text { allowance } \\
\text { including } \\
\text { sweep }\end{array}$ & $\begin{array}{l}\text { Maximum } \\
\text { weevil } \\
\text { injury }\end{array}$ & $\begin{array}{l}\text { Allowable knot size (inches) }{ }^{2} \text { on three best faces or } \\
\text { minimum clearness of four faces }\end{array}$ \\
\hline \multirow[t]{2}{*}{1} & $\begin{array}{l}\text { Inches } \\
12 \& 13\end{array}$ & $\begin{array}{l}\text { Feet } \\
8-16\end{array}$ & \multicolumn{2}{|c|}{--------Percent-------- } & $\begin{array}{c}\text { Number } \\
0\end{array}$ & $\begin{array}{l}\text { Inches } \\
\text { Four faces clear full length }\end{array}$ \\
\hline & $14+$ & $10-16$ & 20 & 50 & 0 & $\begin{array}{l}\text { Two faces clear full length, or four faces clear } 50 \text { percent } \\
\text { length ( } 6 \text { feet min. length) }\end{array}$ \\
\hline 2 & $6+$ & $8-16$ & 30 & 50 & 0 & $\begin{array}{l}\text { Sound knots I.e. }{ }^{4} \mathrm{D} / 6 \text { and less than } 3 \text { inches } 5 \\
\text { Unsound knots: I.e. } 11 / 2 \text { inches and for: butt, lots I.e. } D / \\
12 \text { upper logs I.e. } D / 10 \text { or four faces clear } 50 \text { percent of } \\
\text { length }\end{array}$ \\
\hline 3 & $6+$ & $8-16$ & 40 & 50 & $\begin{array}{c}8 \text {-foot logs } \\
1 \text { weevil } \\
10-\text { foot + logs: } \\
2 \text { weevil }\end{array}$ & $\begin{array}{l}\text { Sound knots I.e. } D / 3 \text { and less than } 5 \text { inches. } \\
\text { Unsound knots I.e.D/6 and less than } \\
21 / 2 \text { inches. }\end{array}$ \\
\hline 4 & $6+$ & $8-16$ & 50 & 50 & No limit & No limit \\
\hline
\end{tabular}

'Plus trim.

${ }^{2}$ Disregard all knots less than $1 / 2$-inch diameter in all grades.

${ }^{3}$ The sum of the diameter of sound knots plus twice the sum of the diameter of unsound knots (in inches) is less than or equal to $1 / 2$ of the diameter of the log (inches).

4.e. means less than or equal to.

${ }^{5} D$ means d.i.b. of log at location of knot.

\section{LOG GRADES FOR JACK PINE AND RED PINE}

Grade 1: logs with three or four clear faces. ${ }^{5}$

Grade 2: logs with one or two clear faces.

Grade 3: logs with no clear faces.

After the tentative log grade is established, the log will be degraded one grade for each of the following, except that no log can be degraded below grade 3 . Net scale after deduction for defect must be at least 50 percent of the gross contents of the log.

1. Sweep. Degrade any tentative 1 or 2 log one grade if sweep amounts to 3 or more inches and equals

${ }^{5} A$ face is one-fourth of the circumference in width extending full length of the log. Clear faces are those free of: knots measuring more than $1 / 2$-inch in diameter, overgrown knots of any size, holes more than 1/4-inch in diameter. Faces may be rotated to obtain the maximum number of clear ones. or exceeds one-third the diameter inside bark at small end.

2. Heart rot. Degrade any tentative 1 or 2 log grade if conk, massed hyphae, or other evidence of advance heart rot is found anywhere in it.

\section{LOG GRADES FOR ALL OTHER SOFTWOOD LOGS}

\section{Grade 1}

1. Logs must be 16 inches in diameter or larger, 10 feet or longer, and with deduction for defect not over 30 percent of gross scale.

2. Logs must be at least 75 percent clear on each of three faces.

3. All knots outside clear cutting must be sound and not over $2-1 / 2$ inches in size.

\section{Grade 2}

1. Logs must be 12 inches in diameter or larger, 10 feet or longer, and with a net scale after deduction 
for defect of at least 50 percent of the gross contents of the log.

2. Logs must be at least 50 percent clear on each of three faces or 75 percent clear on two faces.

\section{Grade 3}

1. Logs must be 6 inches in diameter or larger, 8 feet or longer, and with a net scale after deduction for defect of at least 50 percent of the gross contents of the log.

Note: (A) Diameters are diameter inside bark (d.i.b.) at small end of log.

(B) Percent clear refers to percent clear in one continuous section.

\section{METRIC EQUIVALENTS OF UNITS USED IN THIS REPORT}

1 acre $=4,046.86$ square meters or 0.405 hectare.

1,000 acres $=405$ hectares.

1 cubic foot $=0.0283$ cubic meter.

1 foot $=30.48$ centimeters or 0.3048 meter.

1 inch $=25.4$ millimeters, 2.54 centimeters, or 0.0254 meter.

1 pound $=0.454$ kilogram.

1 ton $=0.907$ metric ton.

\section{TREE SPECIES GROUPS IN WISCONSIN ${ }^{6}$}

\section{SOFTWOODS}

Jack pine Pinus banksiana

Red pine . Pinus resinosa

Eastern white pine ............ Pinus strobus

White spruce ............... Picea glauca

Black spruce .............. Picea mariana

Balsam fir ................... Abies balsamea

Eastern hemlock ........... Tsuga canadensis

Tamarack ................ Larix laricina

Northern white-cedar ...... Thuja occidentalis

Other softwoods

Eastern redcedar ...... Juniperus virginiana

Norway spruce ................Picea abies

Scotch pine .............. Pinus sylvestris

${ }^{6}$ The common and scientific names are based on: Little, Elbert L. Check list of native and naturalized trees of the United States. Agric. Handb. 541. Washington, DC: U.S. Department of Agriculture, Forest Service; 1979. 375 p.

\section{HARDWOODS}

White oaks

White oak

Swamp white oak ............... Quercus bicolor Bur oak ............. Quercus macrocarpa Chinkapin Oak ....... Quercus muehlenbergii

Select red oak

Northern red oak

.Quercus rubra

Other red oaks

Northern pin oak ....... Quercus ellipsoidalis

Black oak .............. Quercus velutina

Select hickory

Shagbark hickory ............ Carya ovata

Other hickory

Bitternut hickory ......... Carya cordiformis

Yellow birch ........... Betula alleghaniensis

Hard maple

Sugar maple .............. Acer saccharum

Black maple ................ Acer nigrum

Soft maples

Red maple .................. Acer rubrum

Silver maple ............ Acer saccharinum

Ashes

White ash .............Fraxinus americana Black ash .............. Fraxinus nigra Green ash ..........Fraxinus pennsylvanica Balsam poplar ........... Populus balsamifera Eastern cottonwood .......... Populus deltoides Sycamore ............. Platanus occidentalis Aspens

Bigtooth aspen ....... Populus grandidentata

Quaking aspen ......... Populus tremuloides American basswood ............Tilia americana Beech .................. Fagus grandifolia Black walnut ................ Juglans nigra Black cherry ............... Prunus serotina Butternut .................. Juglans cinerea Elms

American elm .......... Ulmus americana Slippery elm ............... Ulmus rubra Rock elm ............... Ulmus thomasii

Hackberry .............. Celtis occidentalis Paper birch ............. Betula papyrifera Black willow ................ Salix nigra Other hardwoods

Boxelder ................. Acer negundo Black locust ......... Robinia pseudoacacia Honeylocust .......... Gladitsia triacanthos River birch ............... Betula nigra Red mulberry ............... Morus rubra Blackgum ................ Nyssa silvatica Northern Catalpa ........ Catalpa speciosa Noncommercial species

Mountain maple .............Acer spicatum Eastern hophornbeam ..... Ostrya virginiana Peachleaf willow ........ Salix amygdaloides 
American hornbeam .... Carpinus caroliniana Hawthorn .............. Crataegus spp.

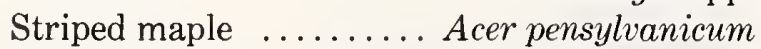
Mountain ash ............... Sorbus spp. Pin cherry ............. Prunus pensylvanica Chokecherry ............Prunus virginiana

\section{DEFINITION OF TERMS}

Basal area.--The area is square feet of the cross section at breast height of a single tree. When the basal area of all trees in a stand are summed, the result is usually expressed as square feet of basal area per acre.

Biomass.--The above-ground volume of all live trees (including bark and foliage) reported in green tons. Biomass is made up of 5 components:

Growing-stock bole.--Biomass of a growing-stock tree from a 1-foot stump to a variable 4 -inch top.

Growing-stock tops and limbs.--Biomass of a growing-stock tree from a 1-foot stump minus the growing-stock bole.

Cull bole.--Biomass of a cull tree from a 1-foot stump to a variable 4 -inch top.

Cull tops and limbs.--Biomass of a cull tree from a 1 -foot stump minus the cell bole.

1- to 5-inch trees.--Biomass of all live trees from 1 - to 5 -inches in diameter at breast height.

Commercial forest land.--Forest land producing or capable of producing crops of industrial wood and not withdrawn from timber utilization. (Note: Areas qualifying as commercial forest land are capable of producing more than 20 cubic feet per acre per year of annual growth when managed. Currently inaccessible and inoperable areas are included except when the areas involved are small and unlikely to become suitable for producing industrial wood in the foreseeable future.) Also see definition of pastured commercial forest land.

Commercial species.--Tree species presently or prospectively suitable for industrial wood products. (Note: Excludes species of typically small size, poor form, or inferior quality such as hophornbeam and hawthorn.)

County and municipal land.--Land owned by counties and local public agencies or municipalities, or land leased to these governmental units for 50 years or more.

Cull.--Portions of a tree that are unusable for industrial wood products because of rot, form, or other defect.

Diameter classes.--A classification of trees based on diameter outside bark, measured at breast height ( $4 \frac{1}{2}$ feet above the ground). (Note: D.b.h. is the common abbreviation for diameter at breast height. Two-inch diameter classes are commonly used in
Forest Survey, with the even inch the approximate midpoint for a class. For example, the 6 -inch class includes trees 5.0 through 6.9 inches d.b.h.)

Farm.--Either a place operated as a unit of 10 or more acres from which the sale of agricultural products totals $\$ 50$ or more annually, or a place operated as a unit of less than 10 acres from which the sale of agricultural products for a year amounts to at least $\$ 250$. Places having less than the $\$ 50$ or $\$ 250 \mathrm{~min}$ imum estimated sales in a given year are also counted as farms if they can normally be expected to produce goods in sufficient quantity to meet the requirements of the definition.

Farmer-owned land.--Land owned by farm operators. (Note: Excludes land leased by farm operators from nonfarm owners, such as railroad companies and States.)

Forest land.--Land at least 16.7 percent stocked by forest trees of any size, or formerly having had such tree cover, and not currently developed for nonforest use. (Note: Stocking is measured by comparing specified standards with basal area and/or number of trees, age or size, and spacing.) The minimum area for classification of forest land is 1 acre. Roadside, streamside, and shelterbelt strips of timber must have a crown width of at least 120 feet to qualify as forest land. Unimproved roads and trails, streams, or other bodies of water or clearings in forest areas shall be classed as forest if less than 120 feet wide. Also see definitions for land area, commercial forest land, noncommercial forest land, productive-reserved forest land, stocking, unproductive forest land, and water.

Forest industry land.--Land owned by companies or individuals operating primary wood-using plants.

Forest trees.--Woody plants having a well-developed stem and usually more than 12 feet tall at maturity.

Forest type.--A classification of forest land based on the species forming a plurality of live tree stocking. Major forest types in the State are:

Jack pine.--Forests in which jack pine comprises a plurality of the stocking. Common associates include eastern white pine, red pine, aspen, birch, and oak.)

Red pine.--Forests in which red pine comprises a plurality of the stocking. (Common associates include eastern white pine, jack pine, aspen, birch, and oak.)

White pine.--Forests in which eastern white pine comprises a plurality of the stocking. (Common associates include red pine, aspen, birch, and maple.)

Balsam fir.--Forests in which balsam fir and white spruce comprise a plurality of stocking with balsam fir the most common. (Common associates include white spruce, aspen, maple, birch, northern whitecedar, and spruce.) 
White spruce.--Forests in which white spruce and balsam fir comprise a plurality of the stocking with white spruce the most common. (Common associates include balsam fir, aspen, maple, birch, and northern white-cedar.)

Black spruce.--Forests in which swamp conifers comprise a plurality of the stocking with black spruce the most common. (Common associates include tamarack, northern white-cedar, and balsam fir.)

Northern white-cedar.--Forests in which swamp conifers comprise a plurality of the stocking with northern white-cedar the most common. (Common associates include balsam fir, black ash, spruce, and black spruce.)

Tamarack.--Forests in which swamp conifers comprise a plurality of the stocking with tamarack the most common. (Common associates include black spruce, balsam fir, and aspen.)

Oak-hickory.--Forests in which northern red oak, white oak, bur oak, or hickories, singly or in combination, comprise a plurality of the stocking. (Common associates include jack pine, aspen, birch, and maple.)

Elm-ash-soft maple.--Forests in which lowland elm, ash, cottonwood, and red maple, singly or in combination, comprise a plurality of the stocking. (Common associates include aspen, birch, and balsam fir.)

Maple-birch.--Forests in which sugar maple, basswood, yellow birch, elm, and red maple, singly or in combination, comprise a plurality of the stocking. (Common associates include white pine, elm, hemlock, and basswood.)

Aspen.--Forests in which quaking aspen or bigtooth aspen, singly or in combination, comprise a plurality of the stocking. (Common associates include oak, pine, balsam fir, and paper birch.)

Paper birch.--Forests in which paper birch comprises a plurality of the stocking. (Common associates include maple, aspen, and balsam fir.)

Exotic.--Forests in which species not native to the State comprise a plurality of the stocking. (Mostly Scotch pine plantations.)

Gross area.--The entire area of land and water as determined by the Bureau of the Census, 1970.

Growing-stock trees.--Live trees of commercial species. Excluding rough and rotten dead trees.

Growing-stock volume.--Net volume in cubic feet of growing-stock trees 5 inches d.b.h. and over, from a 1 -foot stump to a minimum 4 inch top diameter outside bark of the central stem or to the point where the central stem breaks into limbs. Cubic feet can be converted to standard cords by dividing by 79. One standard cord is 128 cubic feet of stacked wood, including bark and air.
Hardwoods.--Dicotyledonous trees, usually broadleaved and deciduous.

Idle farmland.--Includes former cropland, orchards, improved pastures, and farm sites not tended within the past 2 years and presently less than 16.7 percent stocked with trees.

Improved pasture.--Land currently improved for grazing by cultivating, seeding, irrigating, or clearing of trees or brush and less than 16.7 percent stocked with live trees.

Indian land.--All lands held in trust by the United States for individual Indians or tribes, or all lands, titles to which are held by individual Indians or tribes, subject to Federal restrictions against alienation.

Land area.--A. Bureau of the Census. The area of dry land and land temporarily or partly covered by water such as marshes, swamps, and river flood plains (omitting tidal flats below mean high tide); streams, sloughs, estuaries, and canals less than one-eighth of a statute mile wide; and lakes, reservoirs, and ponds less than 40 acres in area.

B. Forest Inventory and Analysis. The same as the Bureau of the Census, except minimum width of streams, etc., is 120 feet and minimum size of lakes, etc., is 1 acre.

Live trees.--Growing-stock, rough, and rotten trees 1 inch d.b.h. and larger.

Log grades.--A classification of logs based on external characteristics as indicators of quality or value. (See Appendix for specific grading factors used.)

Logging residues.--The unused growing stock portions of trees cut or killed by logging.

Maintained road.--Any road, hard-topped or other surfaces, that is plowed or graded at least once a year. Includes rights-of-way that are cut or treated to limit herbaceous growth.

Marsh.--Nonforest land that characteristically supports low, generally herbaceous or shrubby vegetation and that is intermittently covered with water.

Merchantable.--Refers to a pulpwood or saw log section that meets pulpwood or saw log specifications, respectively.

Miscellaneous federal land.--Federal land other than National Forest, land administered by the Bureau of Land Management, and Indian land.

Miscellaneous private land.--Privately owned land other than forest-industry and farmer-owned land.

Mortality.--The volume of sound wood in growingstock and sawtimber trees that die annually.

National Forest land.--Federal land that has been legally designated as National Forest or purchase units, and other land administered by the USDA Forest Service.

Net annual growth of growing stock.--The annual change in volume of sound wood in live sawtimber 
and poletimber trees and the total volume of trees entering these classes through ingrowth, less volume losses resulting from natural causes.

Net annual growth of sawtimber.--The annual change in the volume of live sawtimber trees and the total volume of trees reaching sawtimber size, less volume losses resulting from natural causes.

Net volume.--Gross volume less deductions for rot, sweep, or other defect affecting use for timber products.

Noncommercial forest land.--(a) Unproductive forest land and (b) productive-reserved forest land.

Noncommercial species.--Tree species of typically small size, poor form, or inferior quality that normally do not develop into trees suitable for industrial wood products.

Nonforest land.--Land that has never supported forests, and land formerly forested where use for timber management is precluded by development for other uses. (Note: Includes areas used for crops, improved pasture, residential areas, city parks, improved roads of any width and adjoining clearings, powerline clearings of any width, and 1- to 40 -acre areas of water classified by the Bureau of the Census as land. If intermingled in forest areas, unimproved roads and nonforest strips must be more than 120 feet wide and more than 1 acre in area to qualify as nonforest land.)

a. Nonforest land without trees.--Nonforest land with no live trees present.

b. Nonforest land with trees.--Nonforest land with one or more trees per acre at least 5 inches d.b.h.

Nonstocked land.--Commercial forest land less than 16.7 percent stocked with growing-stock trees.

Other removals.--Growing-stock trees removed but not utilized for products, or trees left standing but "removed" from the commercial forest land classification by land use change. Examples are removals from cultural operations such as timber stand improvement work, land clearing, and changes in land use.

Ownership.--Property owned by one owner, regardless of the number of parcels in a specified area.

Ownership size class.--The amount of commercial forest land owned by one owner, regardless of the number of parcels.

Owner tenure.--The length of time a property has been held by the owner.

Physiographic class.--A measure of soil and water conditions that affect tree growth on a site. The physiographic classes are:

Xeric sites.--Very dry soils where excessive drainage limits growth and species occurrence. Example: sandy jack pine plains.

Xeromesic sites.--Moderately dry soils where excessive drainage limits growth and species occur- rence to some extent. Example: dry oak ridge.

Mesic sites.--Deep, well-drained soils. Growth and species occurrence are limited only by climate.

Hydromesic sites.--Moderately wet soils where insufficient drainage or infrequent flooding limits growth and species occurrence to some extent. Example: better drained bottomland hardwood sites.

Hydric sites.--Very wet sites where excess water seriously limits both growth and species occurrence. Example: frequently flooded river bottoms and spruce bogs.

Plant byproducts.--Plant residues used for products such as mulch, pulp chips, and fuelwood.

Plant residues.--Wood and bark materials generated at manufacturing plants during production of other products.

Poletimber stands.--(See stand-size class.)

Poletimber trees.--Growing-stock trees of commercial species at least 5 inches d.b.h. but smaller than sawtimber size.

Productive-reserved forest land.--Forest land sufficiently productive to qualify as commercial forest land but withdrawn from timber utilization through statute, administration regulation, designation, or exclusive use for Christmas tree production, as indicated by annual shearing.

Productive-deferred.--Forest land sufficiently productive to qualify as commercial forest land but presently withdrawn from timber utilization because it is being considered for possible inclusion into the Wilderness system.

Rotten trees.--Live trees of commercial species that do not contain at least one 12 -foot saw log or two saw logs 8 feet or longer, now or progressively, and/ or do not meet regional specifications for freedom from defect primarily because of rot; that is, when more than 50 percent of extra cull volume in a tree is rotten.

Rough trees.--(a) Live trees of commercial species that do not contain at least one merchantable 12foot saw log or two saw logs 8 feet or longer, nor or prospectively, and/or do not meet regional specifications for freedom from defect primarily because of roughness or poor form, and (b) all live trees of noncommercial species.

Roundwood products.--Logs, bolts, or other round sections (including chips from roundwood) cut from trees for industrial or consumer uses. (Note: Includes saw logs, veneer logs and bolts; cooperage logs and bolts; pulpwood, fuelwood; piling; poles; posts; hewn ties; mine timbers; and various other round, split, or hewn products.)

Salvable dead trees.--Standing or down dead trees considered merchantable by regional standards.

Saplings.--Live trees 1 to 5 inches d.b.h.

Sapling-seedling stands.--(See stand-size class.) 
Saw log.--A log meeting minimum standards of diameter, length, and defect, including logs at least 8 feet long, sound and straight and with a minimum diameter outside bark (d.o.b.) for softwoods of 7 inches (9 inches for hardwoods) or other combinations of size and defect specified by regional standards.

Saw log portion... That part of the bole of sawtimber trees between the stump and the saw log top.

Saw log top.--The point on the bole of sawtimber trees above which a saw log cannot be produced. The minimum saw $\log$ top is 7 inches d.o.b. for softwoods and 9 inches d.o.b. for hardwoods.

Sawtimber stands.--(See stand-size class.)

Saw timber trees.--Growing-stock trees of commercial species containing at least a 12 -foot saw log or two noncontiguous saw logs 8 feet or longer, and meeting regional specifications for freedom from defect. Softwoods must be at least 9 inches d.b.h. Hardwoods must be at least 11 inches d.b.h.

Sawtimber volume.--Net volume of the saw log portion of live sawtimber in board feet, International $1 / 4$-inch rule, from stump to a minimum 7 inches top diameter outside bark (d.o.b.) for softwoods and a minimum 9 inches top d.o.b. for hardwoods.

Seedlings.--Live trees less than 1 inch d.b.h. that are expected to survive. Only softwood seedlings more than 6 inches tall and hardwood seedlings more than 1 foot tall are counted.

Short-log (rough tree).--Sawtimber-size trees of commercial species that contain at least one merchantable 8- to 11 -foot saw $\log$ but not a 12 -foot saw $\log$.

Shrub biomass.--The total above-ground weight (including the bark) of selected shrubs and trees less than 1 inch d.b.h.

Site class.--A classification of forest land in terms of inherent capacity to grow crops of industrial wood based on fully stocked natural stands.

Site index.--An expression of forest site quality based on the height of a free-growing dominant or codominant tree of a representative species in the forest type at age 50.

Softwoods.--Coniferous trees, usually evergreen, having needles or scale-like leaves.

Stand.--A growth of trees on a minimum of 1 acre of forest land that is stocked by forest trees of any size.

Stand-age class.--Age of the main stand. Main stand refers to trees of the dominant forest type and stand-size class.

Stand-area class.--The extent of a continuous forested area of the same forest type, stand-size class, and stand-density class.

Stand-size class.--A classification of forest land based on the size class of growing-stock trees on the area; that is, sawtimber, poletimber, or seedlings and saplings.

a. Sawtimber stands.--Stands at least 16.7 percent stocked with growing-stock trees, with half or more of total stocking in sawtimber or poletimber trees, and with sawtimber stocking at least equal to poletimber stocking.

b. Poletimber stands.--Stands at least 16.7 percent stocked with growing-stock trees of which half or more of this stocking is in poletimber and/or sawtimber trees, and with poletimber stocking exceeding that of sawtimber.

c. Sapling-seedling stands.--Stands at least 16.7 percent stocked with growing-stock trees of which more than half of the stocking is saplings and/or seedlings.

d. Nonstocked stands.--Stands in which stocking of growing-stock trees is less than 16.7 percent.

State land.--Land either owned by States or leased to them, for 50 years or more.

Stocking.--The degree of occupancy of land by trees, measured by basal area and/or the number of trees in a stand by size or age and spacing, compared to the basal area and/or number of trees required to fully utilize the growth potential of the land; that is, the stocking standard.

A stocking percent of 100 indicates full utilization of the site and is equivalent to 80 square feet of basal area per acre in 5 inches d.b.h. and larger. In a stand of trees less than 5 inches d.b.h., a stocking percent of 100 would indicate that the present number of trees is sufficient to produce 80 square feet of basal area per acre when the trees reach 5 inches d.b.h.

Stands are grouped into the following stocking classes:

Overstocked stands.--Stands in which stocking of trees is 134.0 percent or more.

Fully stocked stands.--Stands in which stocking of trees is from 101.0 to 133.9 percent.

Medium stocked stands.--Stands in which stocking of trees is from 61.0 to 100.9 percent.

Poorly stocked stands.--Stands in which stocking of trees is from 16.7 to 60.9 percent.

Nonstocked areas.--Commercial forest land on which stocking of trees is less than 16.7 percent.

Timber removals from growing stock.-- The volume of sound wood in growing-stock trees removed annually for forest products (including roundwood products and logging residues) and for other removals.

Timber removals from sawtimber.--The net board-foot volume of life sawtimber trees removed for forest products annually (including roundwood products and logging residues) and for other removals. 
Timber products output.--All timber products cut from roundwood and byproducts of wood manufacturing plants. Roundwood products include logs, bolts, or other round sections cut from growingstock trees, cull trees, salvable dead trees, trees on nonforest land, noncommercial species, sapling-size trees, and limbwood. Byproducts from primary manufacturing plants include slabs, edging, trimmings, miscuts, sawdust, shavings, veneer cores and clippings, and screenings of pulpmills that are used as pulpwood chips or other products.

Tree biomass.--The total aboveground weight (including the bark) of all trees from 1 to 5 inches in d.b.h., and the total aboveground weight (including the bark) from a 1-foot stump for trees more than 5 inches in diameter.

Tree size class.--A classification of trees based on diameter at breast height, including sawtimber trees, poletimber trees, saplings, and seedlings.

Unproductive forest land.--Forest land incapable of producing 20 cubic feet per acre of annual growth or of yielding crops of industrial wood under natural conditions because of adverse site conditions. (Note: Adverse conditions include shallow soil, dry climate, poor drainage, high elevation, steepness, and rockiness).

Upper stem portion.--That part of the bole of sawtimber trees above the saw $\log$ top to a minimum top diameter of 4 inches outside bark or to the point where the central stem breaks into limbs.

Urban and other areas.--Areas within the legal boundaries of cities and towns; suburban areas developed for residential, industrial, or recreational purposes; schoolyards; cemeteries; roads; railroads; airports; beaches; powerlines; and other rights-ofway; or other nonforest land not included in any other specified land use class.

Water.--(a) Bureau of the Census.--Permanent inland water surfaces, such as lakes, reservoirs, and ponds at least 40 acres in area; and streams, sloughs, estuaries, and canals at least one-eighth of a statute mile wide.

(b) Noncensus.--Permanent inland water surfaces, such as lakes, reservoirs, and ponds from 1 to 39.9 acres in area; and streams, sloughs, estuaries, and canals from 120 feet to one-eighth of a statute mile wide.

Wooded pasture.--Improved pasture with more than 16.7 percent stocking in live trees but less than 25 percent stocking in growing-stock trees. Area is currently improved for grazing or there is other evidence of grazing.

Wooded strip.--An acre or more of natural continuous forest land that would otherwise meet survey standards for commercial forest land except that it is less than 120 feet wide.

\section{TABLES}

\section{AREA}

Table 1.--Area of land by land class, 1968 and 1983

Table 2.--Area of land by land use class and county

Table 3.--Area of commercial forest land by ownership class and county

Table 4.--Area of commercial forest land by ownership class and site class

Table 5.--Area of commercial forest land by ownership class and stand-volume class

Table 6.--Area of privately owned commercial forest land by ownership class, owner tenure, and size of holding

Table 7.--Area of commercial forest land by forest type, stand-size class, and ownership class

Table 8.--Area of commercial forest land by forest type and county

Table 9.--Area of commercial forest land by county and stand-size class

Table 10.--Area of commercial forest land by forest type, stand-size class, and site class

Table 11.--Area of commercial forest land by forest type and stand-age class
Table 12.--Area of commercial forest land by forest type and site-index class

Table 13.--Area of commercial forest land by forest type, stand-size class, and basal-area class

Table 14.--Area of commercial forest land by stocking class of growing-stock trees and stand-size class

Table 15.--Area of commercial forest land in plantations by forest type and stand-age class

Table 16.--Area of commercial forest land with conifer understory by forest type and conifer understory species

Table 17.--Area of noncommercial forest land by ownership class

Table 18.--Area of noncommercial forest land by forest type

\section{NUMBER OF TREES}

Table 19.--Number of all live trees on commercial forest land by species group and diameter class

Table 20.--Number of growing-stock trees on commercial forest land by species group and diameter class 


\section{VOLUME}

Table 21.--Net volume of growing stock on commercial forest land by species group

Table 22.--Net volume of all live trees on commercial forest land by species group and diameter class

Table 23.--Net volume of timber on commercial forest land by class of timber and softwoods and hardwoods

Table 24.--Net volume of growing stock, sawtimber, short-log, and rough and rotten trees on commercial forest land by individual species

Table 25.--Net volume of noncommecial species on commercial forest land by individual species

Table 26.--Net volume of growing stock on commercial forest land by species group and county

Table 27.--Net volume of sawtimber on commercial forest land by species group and county

Table 28.--Net volume of growing stock on commercial forest land by species group and diameter class

Table 29.--Net volume of sawtimber on commercial forest land by species group and diameter class

Table 30.--Net volume of growing stock on commercial forest land by species group and forest type

Table 31.--Net volume of sawtimber on commercial forest land by species group and forest type

Table 32.--Net volume of growing stock on commercial forest land by species group and ownership class

Table 33.--Net volume of sawtimber on commercial forest land by species group and ownership class

Table 34.--Net volume of growing stock on commercial forest land by forest type and stand-age class

Table 35.--Net volume of sawtimber on commercial forest land by forest type and stand-age class

Table 36.--Net volume of growing stock on commercial forest land by forest type, stand-size class, and basal-area class

Table 37.--Net volume of sawtimber on commercial forest land by forest type, stand-size class, and basal-size class

Table 38.--Net volume of sawtimber on commercial forest land by species group and butt log grade

Table 39.--Net volume of short-log trees on commercial forest land by species group and diameter class (cubic feet)
Table 40.--Net volume of short-log trees on commercial forest land by species group and diameter class (board feet)

\section{GROWTH AND REMOVALS}

Table 41.--Net annual growth of growing stock on commercial forest land by softwoods and hardwoods

Table 42.--Net annual growth of growing stock on commercial forest land by species group and county

Table 43.--Net annual growth of sawtimber on commercial forest land by species group and county

Table 44.--Net annual growth of growing stock on commercial forest land by ownership class and softwoods and hardwoods

Table 45.--Net annual growth of growing stock on commercial forest land by species group and type

Table 46.--Net annual growth of sawtimber on commercial forest land by species group and type

Table 47.--Net annual growth of growing stock on commercial forest land by forest type, stand-size class, and basal-area class

Table 48.--Net annual growth of sawtimber on commercial forest land by forest type, standsize class, and basal-area class

Table 49.--Current annual growing stock removals on commercial forest land by species group and county

Table 50.--Current annual sawtimber removals on commercial forest land by species group and county

Table 51.--Average annual growing-stock removals on commercial forest land by species group and county

Table 52.--Average annual sawtimber removals on commercial forest land by species group and county

Table 53.--Current annual growing-stock and sawtimber removals on commercial forest land by species group

Table 54.--Current annual growing-stock and sawtimber removals on commercial forest land by item and species category

\section{MORTALITY}

Table 55.--Annual mortality of growing stock on commercial forest land by softwoods and hardwoods, 1967 and 1982 
Table 56..--Annual mortality of growing stock on commercial forest land by species group and cause

Table 57.--Annual mortality of sawtimber on commercial forest land by species group and cause

Table 58.--Annual mortality of growing stock and sawtimber on commercial forest land by county and softwoods and hardwoods

Table 59.--Annual mortality of growing stock and sawtimber on commercial forest land by ownership class and softwoods and hardwoods

\section{TIMBER PRODUCTS OUTPUT}

Table 60.--Output of timber products by product, softwoods and hardwoods, and source of material

Table 61.--Output of roundwood products by product, softwoods and hardwoods, and source of material
Table 62.--Timber products from roundwood by species group and product

Table 63.--Volume of primary plant residue by use and type of residue

\section{BIOMASS}

Table 64..--All live tree biomass on commercial forest land by species group and forest type

Table 65.--All live tree biomass by species group and tree biomass component

\section{SAMPLING ERRORS}

Table 66.--Sampling errors for estimates smaller than the Unit totals of growing-stock volume, net growth, removals, and area of commercial forest land

Table 67.--Sampling errors for county totals of growing-stock volume, net growth, removals, and area of commercial forest land.

Table 1.--Area of land by land class, Central Unit, Wisconsin, 1968 and 1983

(In thousand acres)

\begin{tabular}{|c|c|c|}
\hline Land class & 1968 & 1983 \\
\hline $\begin{array}{l}\text { Forest land } \\
\text { Commercial forest land } \\
\text { Jack pine } \\
\text { Red pine } \\
\text { White pine } \\
\text { 8alsam fir } \\
\text { White spruce } \\
\text { Black spruce } \\
\text { Northern white-cedar } \\
\text { Tamarack } \\
\text { Oak-hickory } \\
\text { Elm-ash-soft maple } \\
\text { Maple-birch } \\
\text { Aspen } \\
\text { Paper birch } \\
\text { Exotic } \\
\text { Nonstocked }\end{array}$ & $\begin{array}{r}255.7 \\
68.6 \\
59.5 \\
11.9 \\
2.2 \\
9.0 \\
11.1 \\
43.6 \\
861.6 \\
217.5 \\
390.6 \\
688.4 \\
111.0 \\
-.- \\
101.1\end{array}$ & $\begin{array}{r}203.1 \\
135.5 \\
77.9 \\
11.9 \\
2.2 \\
11.6 \\
23.3 \\
39.0 \\
937.6 \\
271.5 \\
506.2 \\
577.5 \\
118.6 \\
2.2 \\
32.8\end{array}$ \\
\hline Subtotal & $2,831.8$ & $2,950.9$ \\
\hline $\begin{array}{l}\text { Noncommercial forest land } \\
\text { Unproductive } \\
\text { Productive-reserved }\end{array}$ & $\begin{array}{r}21.7 \\
3.9 \\
\end{array}$ & $\begin{array}{l}21.5 \\
30.1 \\
\end{array}$ \\
\hline Subtotal & 25.6 & 51.6 \\
\hline Total & $2,857.4$ & $3,002.5$ \\
\hline $\begin{array}{l}\text { Nonforest land } \\
\text { Cropland } \\
\text { Pasture and range } \\
\text { Other }\end{array}$ & $\begin{array}{r}2,489.7 \\
423.3 \\
1,430.9 \\
\end{array}$ & $\begin{array}{r}2,441.0 \\
538.7 \\
1,188.0 \\
\end{array}$ \\
\hline Total & $4,343.9$ & $4,167.7$ \\
\hline Total land & $7,201.3$ & $7,170.2$ \\
\hline Water (Bureau of the Census) & $111.41 /$ & 114.62 \\
\hline Total land and water & $7,312.71 /$ & $7,284.821$ \\
\hline
\end{tabular}


Table 2.--Area of 1 and by 1 and use class and county, Central Unit, Wisconsin, 1983

(In thousand acres)

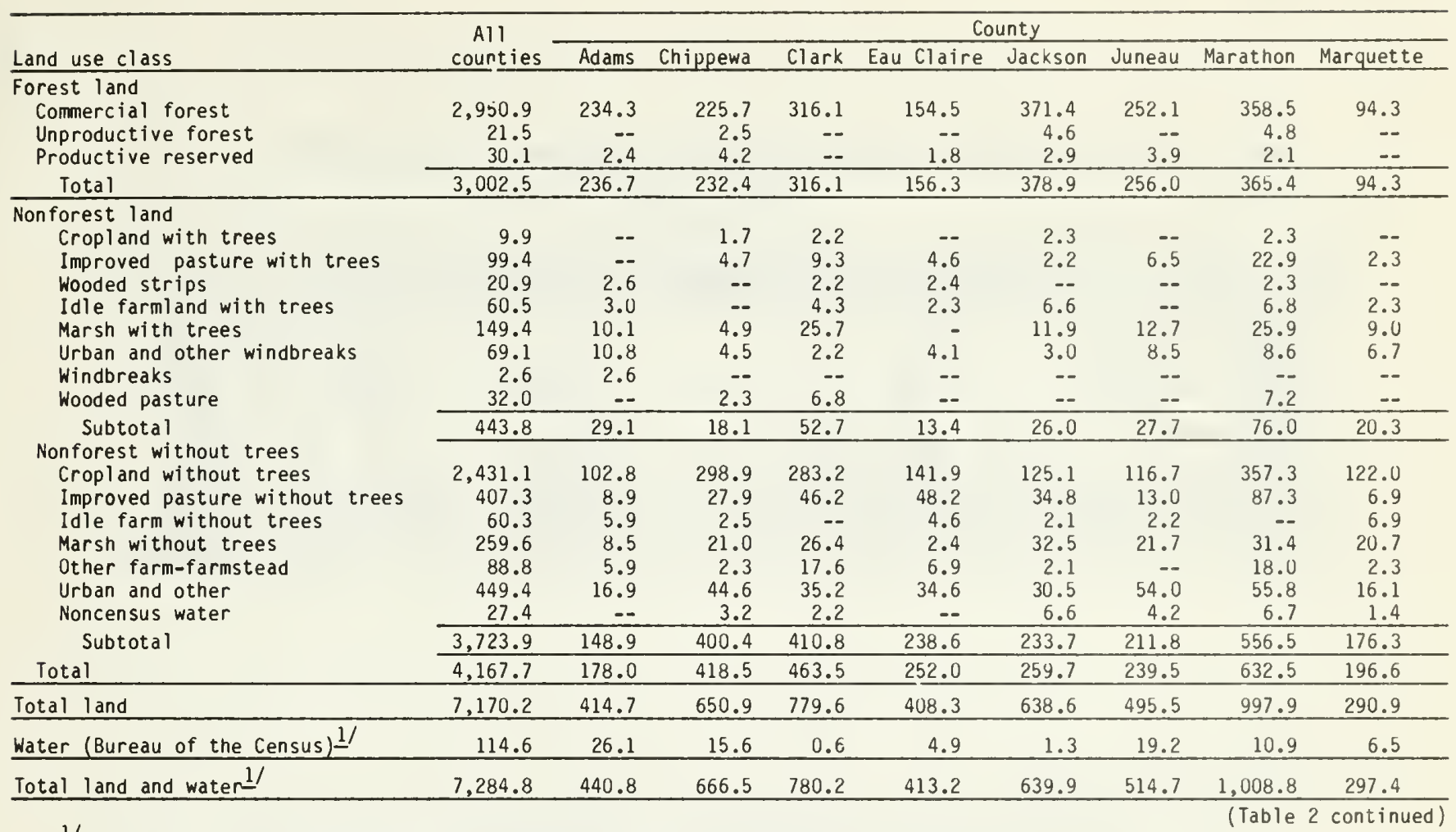

1/U.S. Department of Commerce, Bureau of Census, 1980.

(Table 2 continued)

\begin{tabular}{|c|c|c|c|c|c|}
\hline \multirow[b]{2}{*}{ Land use class } & \multicolumn{5}{|c|}{ County } \\
\hline & Monroe & Portage & Waupaca & Waushara & Wood \\
\hline \multicolumn{6}{|l|}{ Forest land } \\
\hline Commercial forest & 245.0 & 174.3 & 172.6 & 145.6 & 206.5 \\
\hline Unproductive forest & 2.3 & -- & 7.3 & -- & -- \\
\hline Productive reserved & -- & -- & 1.2 & 11.6 & -- \\
\hline Total & 247.3 & 174.3 & 181.1 & 157.2 & 206.5 \\
\hline \multicolumn{6}{|l|}{ Nonforest land } \\
\hline Cropland with trees & - & - & 1.4 & - & - \\
\hline Improved pasture with trees & 6.9 & 10.3 & 3.7 & 12.8 & 13.2 \\
\hline Wooded strips & 2.2 & 2.2 & 2.4 & 2.3 & 2.3 \\
\hline Idle farmland with trees & -- & 8.8 & 8.5 & 11.2 & 6.7 \\
\hline Marsh with trees & 4.4 & 5.9 & 12.0 & 6.7 & 20.2 \\
\hline Urban and other windbreaks & 2.2 & 5.8 & 6.2 & 2.3 & 4.2 \\
\hline Windbreaks & -- & -- & -- & -- & -- \\
\hline Wooded pasture & 11.3 & 4.4 & -- & - & - \\
\hline \multirow{2}{*}{\multicolumn{6}{|c|}{$\begin{array}{l}\text { Subtotal } \\
\text { Nonforest without trees }\end{array}$}} \\
\hline & & & & & \\
\hline Cropland without trees & 164.2 & 203.6 & 205.3 & 163.8 & 146.3 \\
\hline Improved pasture without trees & 68.8 & 28.8 & 11.5 & 6.8 & 18.2 \\
\hline Idle farm without trees & 4.4 & 8.9 & 9.2 & -- & 13.6 \\
\hline Marsh without trees & 4.4 & 20.1 & 18.5 & 18.3 & 33.7 \\
\hline Other farm-farmstead & 9.0 & 11.1 & 9.2 & -- & 4.4 \\
\hline Urban and other & 53.2 & 31.2 & 13.8 & 20.3 & 43.2 \\
\hline Noncensus water & -- & 3.1 & -- & -- & -- \\
\hline Subtotal & 304.0 & 306.8 & 267.5 & 209.2 & 259.4 \\
\hline Total & 331.0 & 344.2 & 301.7 & 244.5 & 306.0 \\
\hline Total land & 578.3 & 518.5 & 482.8 & 401.7 & 512.5 \\
\hline Water (Bureau of the Census) 1 / & 3.0 & 8.3 & 6.7 & 6.4 & 5.1 \\
\hline Total land and water-1/ & 581.3 & 526.8 & 489.5 & 408.1 & 517.6 \\
\hline
\end{tabular}

1/U.S. Department of Commerce, Bureau of Census, 1980. 
Table 3.--Area of commercial forest land by ownership class and county, Central Unit, Wisconsin, 1983

(In thousand acres)

\begin{tabular}{|c|c|c|c|c|c|c|c|c|}
\hline \multirow[b]{2}{*}{ Ownership class } & \multirow{2}{*}{$\begin{array}{c}\text { All } 1 \\
\text { counties }\end{array}$} & \multicolumn{7}{|c|}{ County } \\
\hline & & Adams & Chippewa & Clark & Eau Claire & Jackson & Juneau & Marathon \\
\hline $\begin{array}{l}\text { National Forest } \\
\text { Miscellaneous federal } \\
\text { State } \\
\text { County and municipal } \\
\text { Indian } \\
\text { Forest industry } \\
\text { Farmer } \\
\text { Misc. private-corporation } \\
\text { Misc. private-individual }\end{array}$ & $\begin{array}{r}-- \\
130.6 \\
96.6 \\
399.3 \\
4.6 \\
126.0 \\
996.7 \\
129.5 \\
1,067.6 \\
\end{array}$ & $\begin{array}{r}-- \\
-- \\
7.0 \\
2.3 \\
-- \\
33.5 \\
37.6 \\
14.4 \\
139.5 \\
\end{array}$ & $\begin{array}{r}-- \\
-\overline{-} \\
4.7 \\
22.3 \\
-- \\
-- \\
102.0 \\
17.5 \\
79.2 \\
\end{array}$ & $\begin{array}{r}-- \\
-- \\
-\overline{-} \\
134.1 \\
-\overline{2.4} \\
101.8 \\
4.9 \\
72.9 \\
\end{array}$ & $\begin{array}{r}-- \\
-- \\
2.4 \\
54.7 \\
-- \\
-- \\
33.3 \\
2.4 \\
61.7 \\
\end{array}$ & $\begin{array}{r}-\overline{-} \\
29.4 \\
42.1 \\
87.9 \\
2.2 \\
20.4 \\
124.1 \\
4.6 \\
60.7 \\
\end{array}$ & $\begin{array}{r}--- \\
55.9 \\
4.2 \\
15.0 \\
-- \\
6.6 \\
49.4 \\
21.6 \\
99.4\end{array}$ & $\begin{array}{r}-- \\
7 .- \\
26.1 \\
2.4 \\
32.9 \\
163.1 \\
14.0 \\
112.9\end{array}$ \\
\hline All owners & $2,950.9$ & 234.3 & 225.7 & 316.1 & 154.5 & 371.4 & 252.1 & 358.5 \\
\hline
\end{tabular}

(Table 3 continued)

\begin{tabular}{lrrrrrr}
\hline & \multicolumn{7}{c}{ County } \\
\cline { 2 - 7 } Ownership class & Marquette & Monroe & Portage & Waupaca & Waushara & Wood \\
\hline National Forest & -- & -- & -- & -- & -- & -- \\
Miscellaneous federal & -- & 45.3 & -- & -- & -- & -- \\
State & -- & -- & 11.0 & -- & 11.3 & 6.8 \\
County and municipal & -- & 9.1 & -- & -- & -- & 47.8 \\
Indian & -- & -- & -- & -- & -- & -- \\
Forest industry & -- & -- & 4.4 & 9.8 & 2.3 & 13.7 \\
Farmer & 44.8 & 109.2 & 54.1 & 87.4 & 49.1 & 40.8 \\
Misc. private-corporation & -- & 11.4 & 2.2 & 4.9 & 15.8 & 15.8 \\
Misc. private-individual & 49.5 & 70.0 & 102.6 & 70.5 & 67.1 & 81.6 \\
\cline { 2 - 7 } All owners & 94.3 & 245.0 & 174.3 & 172.6 & 145.6 & 206.5 \\
\hline
\end{tabular}


Table 4.--Area of commercial forest land by ownership class and site class, Central Unit, Wisconsin, 1983

(In thousand acres)

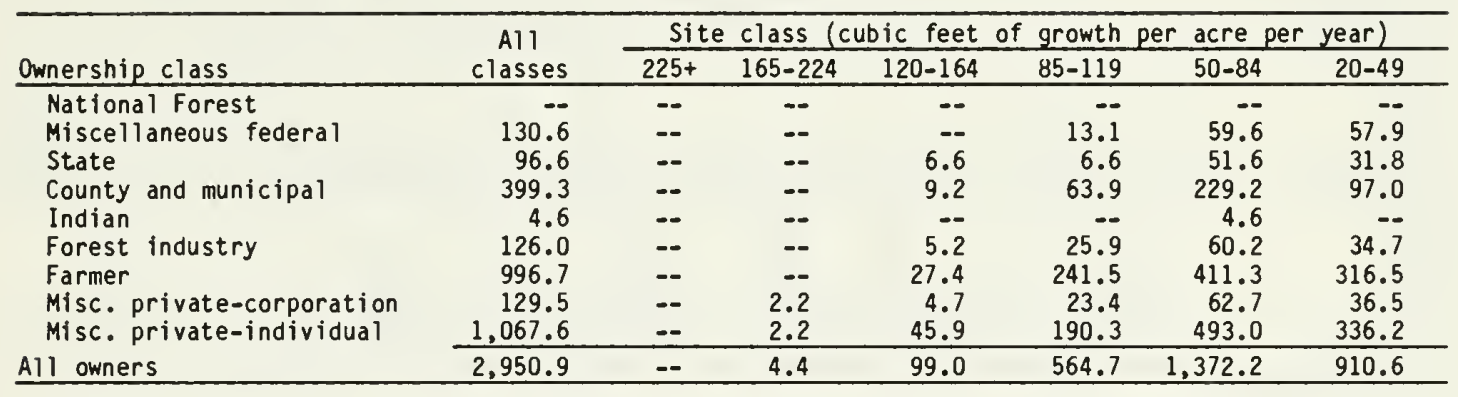

Table 5.--Area of commercial forest land by ownership class and stand-volume class, Central Unit, Wisconsin, 1983

(In thousand acres)

\begin{tabular}{|c|c|c|c|c|}
\hline \multirow[b]{2}{*}{ Ownership class } & \multirow[b]{2}{*}{$\begin{array}{c}\text { A11 } \\
\text { classes } \\
\end{array}$} & \multicolumn{3}{|c|}{ Stand-volume class (board feet $1 /$ ) } \\
\hline & & $\begin{array}{c}\text { Less than } \\
1,500\end{array}$ & $\begin{array}{c}1,500 \text { to } \\
5,000\end{array}$ & $5,000+$ \\
\hline $\begin{array}{l}\text { National Forest } \\
\text { Miscellaneous federal } \\
\text { State } \\
\text { County and municipal } \\
\text { Indian } \\
\text { Forest industry } \\
\text { Farmer } \\
\text { Misc. private-corporation } \\
\text { Misc. private-individual }\end{array}$ & $\begin{array}{r}130.6 \\
96.6 \\
399.3 \\
4.6 \\
126.0 \\
996.7 \\
129.5 \\
1,067.6 \\
\end{array}$ & $\begin{array}{r}80.2 \\
60.0 \\
257.6 \\
-.- \\
57.9 \\
444.7 \\
64.5 \\
513.4\end{array}$ & $\begin{array}{r}37.4 \\
27.6 \\
120.2 \\
2.4 \\
42.1 \\
375.9 \\
53.1 \\
406.2 \\
\end{array}$ & $\begin{array}{r}13.0 \\
9.0 \\
21.5 \\
2.2 \\
26.0 \\
176.1 \\
11.9 \\
148.0 \\
\end{array}$ \\
\hline A11 owners & $2,950.9$ & $1,478.3$ & $1,064.9$ & 407.7 \\
\hline
\end{tabular}

1/ International $1 / 4$-inch rule. 
Table 6.--Area of privately owned commercial forest land by ownership class, owner tenure, and size of holding, Central Unit, Wisconsin, 1983

(In thousand acres)

\begin{tabular}{|c|c|c|c|c|c|c|c|c|c|c|}
\hline \multirow[b]{2}{*}{$\begin{array}{l}\text { Ownership class } \\
\text { and owner-tenure class }\end{array}$} & \multirow[b]{2}{*}{$\begin{array}{l}\text { A11 } \\
\text { sizes }\end{array}$} & \multicolumn{8}{|c|}{ Size of holding (acres) } & \multirow[b]{2}{*}{$5001+$} \\
\hline & & $1-4$ & $5-10$ & $11-20$ & $21-50$ & $51-100$ & $\begin{array}{l}101- \\
500\end{array}$ & $\begin{array}{r}501- \\
2,500 \\
\end{array}$ & $\begin{array}{l}2,501- \\
5,000\end{array}$ & \\
\hline $\begin{array}{c}\text { Forest industry } \\
1-4 \text {-years } \\
5-9 \text { years } \\
10-19 \text { years } \\
20+\text { years }\end{array}$ & $\begin{array}{r}4.7 \\
11.7 \\
18.4 \\
91.2 \\
\end{array}$ & $\begin{array}{l}-- \\
-- \\
-- \\
-\end{array}$ & $\begin{array}{l}-- \\
-- \\
-- \\
-\end{array}$ & $\begin{array}{l}-- \\
-- \\
-- \\
--\end{array}$ & $\begin{array}{l}-- \\
-- \\
-- \\
--\end{array}$ & $\begin{array}{r}-- \\
-- \\
- \\
2.3\end{array}$ & $\begin{array}{l}-- \\
-- \\
-- \\
2.3\end{array}$ & $\begin{array}{r}-- \\
2.3 \\
2.3 \\
--\end{array}$ & $\begin{array}{l}-- \\
-- \\
-- \\
-\end{array}$ & $\begin{array}{r}4.7 \\
9.4 \\
16.1 \\
86.6 \\
\end{array}$ \\
\hline All classes & 126.0 & -- & -- & -- & -- & 2.3 & 2.3 & 4.6 & -- & 116.8 \\
\hline $\begin{array}{r}\text { Farmer } \\
1-4 \text { years } \\
5-9 \text { years } \\
10-19 \text { years } \\
20+\text { years }\end{array}$ & $\begin{array}{l}189.2 \\
156.0 \\
323.7 \\
327.8 \\
\end{array}$ & $\begin{array}{l}-- \\
4.9 \\
4.3 \\
2.3 \\
\end{array}$ & $\begin{array}{r}--- \\
6.9 \\
16.0 \\
7.1 \\
\end{array}$ & $\begin{array}{l}18.8 \\
21.6 \\
28.0 \\
38.7 \\
\end{array}$ & $\begin{array}{l}39.1 \\
40.3 \\
73.8 \\
83.1 \\
\end{array}$ & $\begin{array}{r}62.1 \\
38.8 \\
109.0 \\
83.3 \\
\end{array}$ & $\begin{array}{r}62.4 \\
43.5 \\
92.6 \\
104.1 \\
\end{array}$ & $\begin{array}{r}6.8 \\
-- \\
-- \\
9.2 \\
\end{array}$ & $\begin{array}{l}-- \\
-- \\
-- \\
-\end{array}$ & $\begin{array}{l}-- \\
-- \\
-- \\
--\end{array}$ \\
\hline All classes & 996.7 & 11.5 & 30.0 & 107.1 & 236.3 & 293.2 & 302.6 & 16.0 & -- & -- \\
\hline $\begin{array}{c}\text { Misc. priv.-corporation } \\
1-4 \text { years } \\
5-9 \text { years } \\
10-19 \text { years } \\
20+\text { years }\end{array}$ & $\begin{array}{l}25.4 \\
21.0 \\
27.5 \\
55.6\end{array}$ & $\begin{array}{l}-- \\
-- \\
-- \\
--\end{array}$ & $\begin{array}{r}-- \\
-- \\
2.3 \\
--\end{array}$ & $\begin{array}{l}-- \\
-- \\
--\end{array}$ & $\begin{array}{r}11.6 \\
4.5 \\
2.2 \\
2.5\end{array}$ & $\begin{array}{r}4.7 \\
2.3 \\
4.4 \\
--\end{array}$ & $\begin{array}{r}4.3 \\
6.9 \\
4.8 \\
18.9\end{array}$ & $\begin{array}{l}4.8 \\
2.5 \\
9.1 \\
9.1\end{array}$ & $\begin{array}{r}-- \\
2.4 \\
-- \\
7.2\end{array}$ & $\begin{array}{r}-\overline{2} \\
4.4 \\
17.9\end{array}$ \\
\hline All classes & 129.5 & -- & 2.3 & -- & 20.8 & 11.4 & 34.9 & 25.5 & 9.6 & 25.0 \\
\hline $\begin{array}{c}\text { Misc. } \text { priv. }- \text { individual } \\
1-4 \text { years } \\
5-9 \text { years } \\
10-19 \text { years } \\
20+\text { years }\end{array}$ & $\begin{array}{l}250.1 \\
279.3 \\
331.8 \\
206.4 \\
\end{array}$ & $\begin{array}{r}11.5 \\
4.6 \\
6.7 \\
2.4 \\
\end{array}$ & $\begin{array}{r}20.9 \\
13.6 \\
9.2 \\
2.4 \\
\end{array}$ & $\begin{array}{l}22.9 \\
36.1 \\
21.1 \\
19.9\end{array}$ & $\begin{array}{r}83.3 \\
86.9 \\
101.3 \\
71.2 \\
\end{array}$ & $\begin{array}{r}65.2 \\
65.9 \\
103.4 \\
55.1 \\
\end{array}$ & $\begin{array}{l}46.3 \\
65.3 \\
76.2 \\
50.1 \\
\end{array}$ & $\begin{array}{r}-- \\
6.9 \\
13.9 \\
2.4 \\
\end{array}$ & $\begin{array}{l}-- \\
-- \\
-- \\
-\end{array}$ & $\begin{array}{r}-- \\
-- \\
-- \\
2.9\end{array}$ \\
\hline All classes & $1,067.6$ & 25.2 & 46.1 & 100.0 & 342.7 & 289.6 & 237.9 & 23.2 & -- & 2.9 \\
\hline $\begin{array}{l}\text { A11 private owners } \\
1-4 \text { years } \\
5-9 \text { years } \\
10-19 \text { years } \\
20+\text { years }\end{array}$ & $\begin{array}{l}469.4 \\
468.0 \\
701.4 \\
681.0 \\
\end{array}$ & $\begin{array}{r}11.5 \\
9.5 \\
11.0 \\
4.7 \\
\end{array}$ & $\begin{array}{r}20.9 \\
20.5 \\
27.5 \\
9.5 \\
\end{array}$ & $\begin{array}{l}41.7^{\circ} \\
57.7 \\
49.1 \\
58.6\end{array}$ & $\begin{array}{l}134.0 \\
131.7 \\
177.3 \\
156.8 \\
\end{array}$ & $\begin{array}{l}132.0 \\
107.0 \\
216.8 \\
140.7 \\
\end{array}$ & $\begin{array}{l}113.0 \\
115.7 \\
173.6 \\
175.4 \\
\end{array}$ & $\begin{array}{l}11.6 \\
11.7 \\
25.3 \\
20.7 \\
\end{array}$ & $\begin{array}{r}-- \\
2.4 \\
-- \\
7.2\end{array}$ & $\begin{array}{r}4.7 \\
11.8 \\
20.8 \\
107.4 \\
\end{array}$ \\
\hline All classes & $2,319.8$ & 36.7 & 78.4 & 207.1 & 599.8 & 596.5 & 577.7 & 69.3 & 9.6 & 144.7 \\
\hline
\end{tabular}




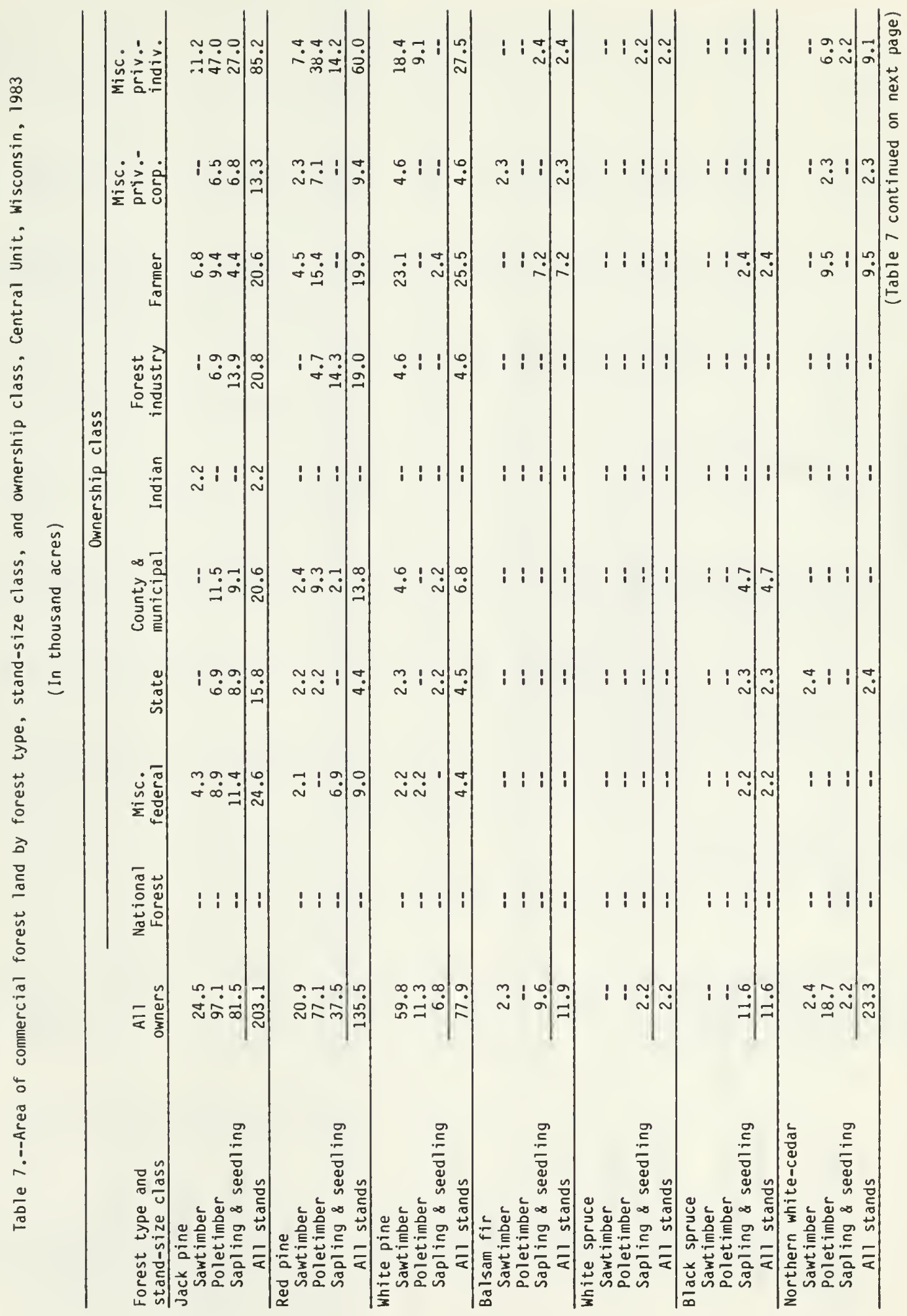




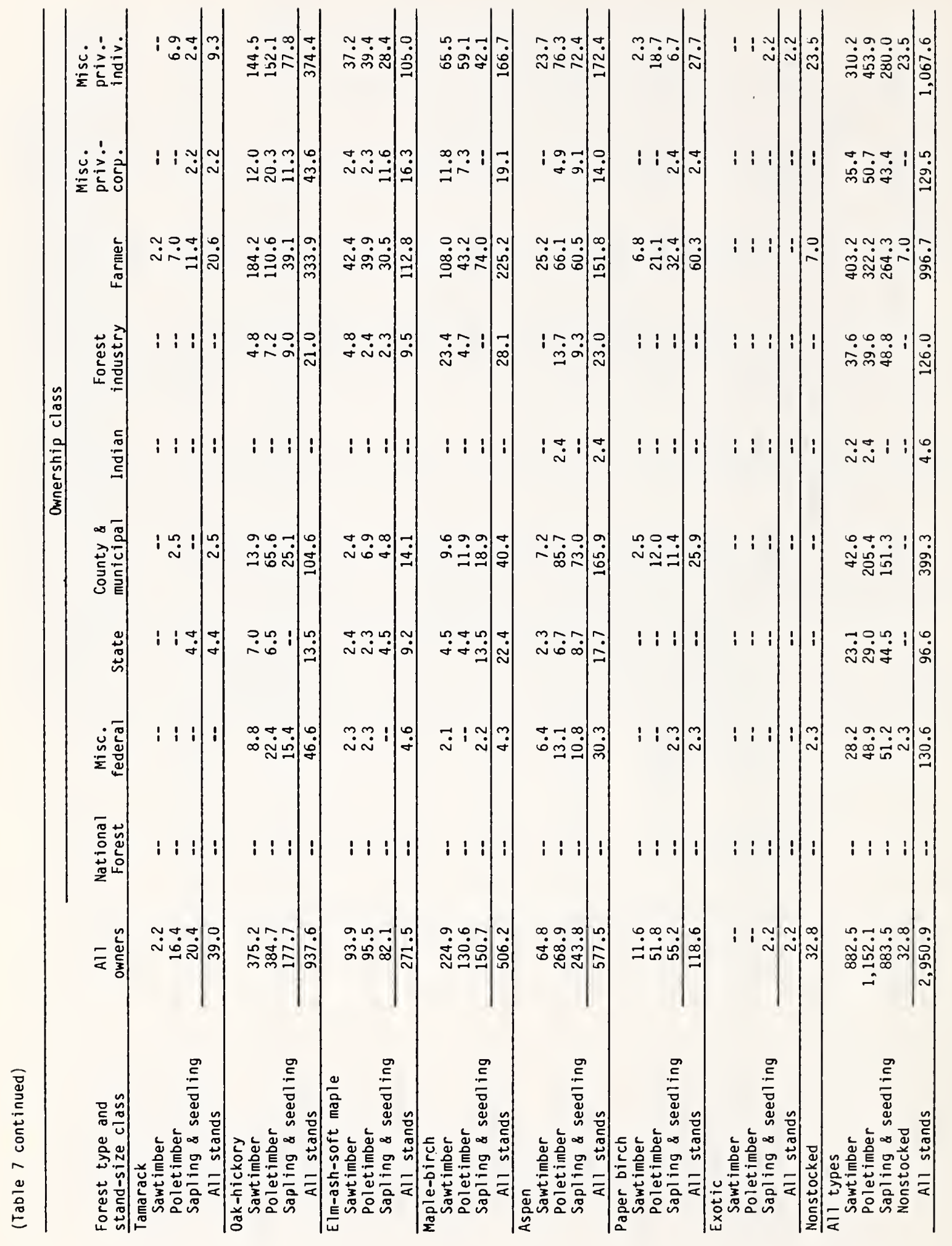



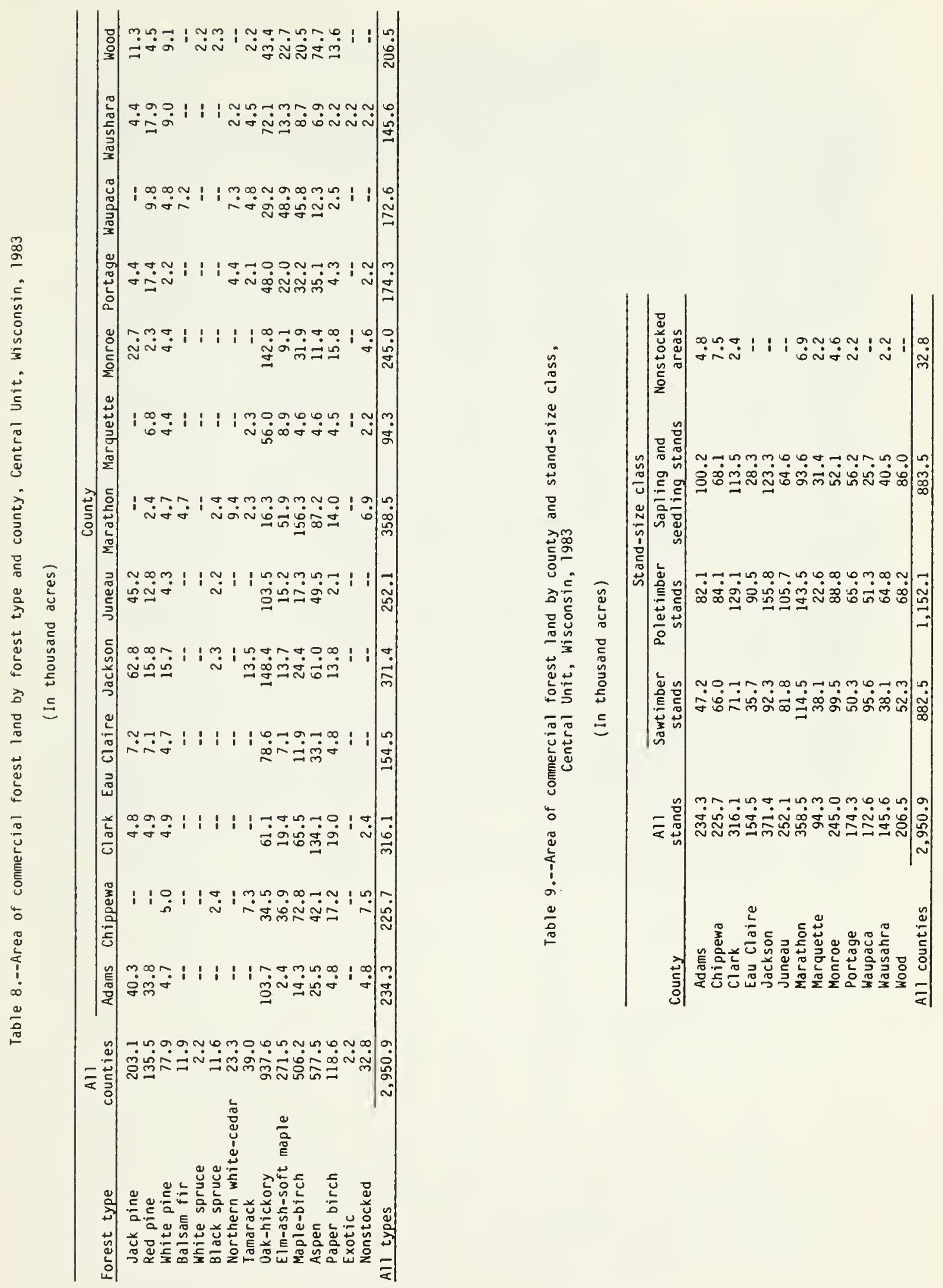
Table 10.--Area of commercial forest land by forest type, stand-size class, and site class, Central Unit, Wisconsin, 1983

\section{(In thousand acres)}

\begin{tabular}{|c|c|c|c|c|c|c|c|}
\hline \multirow{2}{*}{$\begin{array}{l}\text { Forest type and } \\
\text { stand-size class }\end{array}$} & \multirow{2}{*}{$\begin{array}{c}\text { All } \\
\text { classes }\end{array}$} & \multicolumn{6}{|c|}{ Site class (cubic feet of growth per acre per year) } \\
\hline & & $225+$ & $165-224$ & $120-164$ & $85-119$ & $50-84$ & $20-49$ \\
\hline $\begin{array}{l}\text { Jack pine } \\
\text { Sawtimber } \\
\text { Poletimber } \\
\text { Sapling \& seedling }\end{array}$ & $\begin{array}{l}24.5 \\
97.1 \\
81.5 \\
\end{array}$ & $\begin{array}{l}-- \\
-- \\
--\end{array}$ & $\begin{array}{l}-- \\
-- \\
--\end{array}$ & $\begin{array}{l}-- \\
-- \\
-\end{array}$ & $\begin{array}{l}-- \\
7.1 \\
4.5 \\
\end{array}$ & $\begin{array}{l}13.3 \\
63.2 \\
33.8 \\
\end{array}$ & $\begin{array}{l}11.2 \\
26.8 \\
43.2 \\
\end{array}$ \\
\hline All stands & 203.1 & -- & -- & -- & 11.6 & 110.3 & 81.2 \\
\hline $\begin{array}{l}\text { Red pine } \\
\text { Sawt imber } \\
\text { Polet imber } \\
\text { Sapling \& seedling }\end{array}$ & $\begin{array}{l}20.9 \\
77.1 \\
37.5 \\
\end{array}$ & $\begin{array}{l}-- \\
-- \\
--\end{array}$ & $\begin{array}{r}-- \\
4.4 \\
-- \\
\end{array}$ & $\begin{array}{r}6.9 \\
31.7 \\
7.5 \\
\end{array}$ & $\begin{array}{r}4.6 \\
38.8 \\
11.0 \\
\end{array}$ & $\begin{array}{r}7.2 \\
2.2 \\
12.1 \\
\end{array}$ & $\begin{array}{r}2.2 \\
-- \\
6.9 \\
\end{array}$ \\
\hline All stands & 135.5 & -- & 4.4 & 46.1 & 54.4 & 21.5 & 9.1 \\
\hline $\begin{array}{l}\text { White pine } \\
\text { Sawt imber } \\
\text { Poletimber } \\
\text { Sapling \& seedling }\end{array}$ & $\begin{array}{r}59.8 \\
11.3 \\
6.8 \\
\end{array}$ & $\begin{array}{l}-- \\
-- \\
--\end{array}$ & $\begin{array}{l}-- \\
-- \\
--\end{array}$ & $\begin{array}{r}6.7 \\
2.2 \\
--- \\
\end{array}$ & $\begin{array}{r}27.3 \\
4.5 \\
4.6 \\
\end{array}$ & $\begin{array}{l}9.5 \\
4.6 \\
2.2 \\
\end{array}$ & $\begin{array}{r}16.3 \\
-- \\
-- \\
\end{array}$ \\
\hline All stands & 77.9 & -- & -- & 8.9 & 36.4 & 16.3 & 16.3 \\
\hline $\begin{array}{l}\text { Balsam fir } \\
\text { Sawtimber } \\
\text { Poletimber } \\
\text { Sapling \& seedling }\end{array}$ & $\begin{array}{r}2.3 \\
-- \\
9.6 \\
\end{array}$ & $\begin{array}{l}-- \\
-- \\
--\end{array}$ & $\begin{array}{l}-- \\
-- \\
--\end{array}$ & $\begin{array}{r}-- \\
-- \\
2.4 \\
\end{array}$ & $\begin{array}{r}2.3 \\
-- \\
4.8 \\
\end{array}$ & $\begin{array}{r}-- \\
-- \\
2.4 \\
\end{array}$ & $\begin{array}{l}-- \\
-- \\
-\end{array}$ \\
\hline All stands & 11.9 & -- & - & 2.4 & 7.1 & 2.4 & - \\
\hline $\begin{array}{l}\text { White spruce } \\
\text { Sawtimber } \\
\text { Poletimber } \\
\text { Sapling \& seedling }\end{array}$ & $\begin{array}{r}-- \\
-\overline{2} \\
\end{array}$ & $\begin{array}{l}-- \\
-- \\
\end{array}$ & $\begin{array}{l}-- \\
-- \\
-\end{array}$ & $\begin{array}{l}-- \\
--\end{array}$ & $\begin{array}{l}-- \\
-- \\
=\end{array}$ & $\begin{array}{l}-- \\
-- \\
-\end{array}$ & $\begin{array}{r}-- \\
-\overline{2} \\
\end{array}$ \\
\hline All stands & 2.2 & - & -- & - & - & -- & 2.2 \\
\hline $\begin{array}{l}\text { Black spruce } \\
\text { Sawtimber } \\
\text { Poletimber } \\
\text { Sapling \& seedling }\end{array}$ & $\begin{array}{r}-- \\
11.6 \\
\end{array}$ & $\begin{array}{l}-- \\
-- \\
--\end{array}$ & $\begin{array}{l}-- \\
-- \\
--\end{array}$ & $\begin{array}{l}-- \\
-- \\
-\end{array}$ & $\begin{array}{l}-- \\
-- \\
--\end{array}$ & $\begin{array}{r}-- \\
-- \\
4.6 \\
\end{array}$ & $\begin{array}{r}-- \\
7.0 \\
\end{array}$ \\
\hline All stands & 11.6 & $=$ & -- & -- & -- & 4.6 & 7.0 \\
\hline $\begin{array}{l}\text { Northern white-cedar } \\
\text { Sawt imber } \\
\text { Poletimber } \\
\text { Sapl ing \& seedling }\end{array}$ & $\begin{array}{r}2.4 \\
18.7 \\
2.2 \\
\end{array}$ & $\begin{array}{l}-- \\
-- \\
--\end{array}$ & $\begin{array}{l}-- \\
-- \\
--\end{array}$ & $\begin{array}{l}-- \\
-- \\
--\end{array}$ & $\begin{array}{l}-- \\
-- \\
--\end{array}$ & $\begin{array}{r}-- \\
2.4 \\
-- \\
\end{array}$ & $\begin{array}{r}2.4 \\
16.3 \\
2.2 \\
\end{array}$ \\
\hline All stands & 23.3 & $=$ & -- & $=$ & -- & 2.4 & 20.9 \\
\hline
\end{tabular}


(Table 10 continued)

\begin{tabular}{|c|c|c|c|c|c|c|c|}
\hline \multirow{2}{*}{$\begin{array}{l}\text { Forest type and } \\
\text { stand-size class }\end{array}$} & \multirow{2}{*}{$\begin{array}{c}\text { All } \\
\text { classes }\end{array}$} & \multicolumn{2}{|c|}{ Site class ( } & bic feet & \multirow{2}{*}{$\begin{array}{l}\text { growth pe } \\
85-119\end{array}$} & \multicolumn{2}{|c|}{ r acre per year) } \\
\hline & & $225+$ & $165-224$ & $120-164$ & & $50-84$ & $20-49$ \\
\hline \multicolumn{8}{|l|}{ Tamarack } \\
\hline Sawtimber & 2.2 & -- & -- & -- & -- & -- & 2.2 \\
\hline Poletimber & 16.4 & -- & -- & -- & 2.4 & 9.5 & 4.5 \\
\hline Sapling \& seedling & 20.4 & -- & -- & -- & 2.4 & 9.0 & 9.0 \\
\hline All stands & 39.0 & -- & -- & -- & 4.8 & 18.5 & 15.7 \\
\hline \multicolumn{8}{|l|}{ 0ak-hickory } \\
\hline Sawtimber & 375.2 & -- & -- & 4.4 & 83.3 & 176.2 & 111.3 \\
\hline Poletimber & 384.7 & -- & -- & -- & 30.1 & 216.1 & 138.5 \\
\hline Sapling \& seedling & 177.7 & -- & -- & -- & 20.9 & 86.4 & 70.4 \\
\hline All stands & 937.6 & -- & $=$ & 4.4 & 134.3 & 478.7 & 320.2 \\
\hline \multicolumn{8}{|l|}{ Elm-ash-soft maple } \\
\hline Sawt inber & 93.9 & -- & -- & -- & 9.3 & 38.0 & 46.6 \\
\hline Poletimber & 95.5 & -- & -- & -- & 11.7 & 25.4 & 58.4 \\
\hline Sapling \& seedling & 82.1 & -- & -- & -- & 4.7 & 33.2 & 44.2 \\
\hline All stands & 271.5 & -- & -- & -- & 25.7 & 96.6 & 149.2 \\
\hline \multicolumn{8}{|l|}{ Maple-birch } \\
\hline Sawt imber & 224.9 & -- & -- & 2.3 & 35.8 & 109.1 & 77.7 \\
\hline Poletimber & 130.6 & -- & -- & 4.6 & 26.1 & 64.8 & 35.1 \\
\hline Sapling \& seedling & 150.7 & -- & -- & 4.7 & 30.6 & 78.5 & 36.9 \\
\hline All stands & 506.2 & -- & -- & 11.6 & 92.5 & 252.4 & 149.7 \\
\hline \multicolumn{8}{|l|}{ Aspen } \\
\hline Sawt imber & 64.8 & -- & -- & 9.0 & 25.8 & 21.1 & 8.9 \\
\hline Poletimber & 268.9 & -- & -- & 9.4 & 82.1 & 156.5 & 20.9 \\
\hline Sapling \& seedling & 243.8 & -- & -- & 4.9 & 67.0 & 127.3 & 44.6 \\
\hline All stands & 577.5 & -- & -- & 23.3 & 174.9 & 304.9 & 74.4 \\
\hline \multicolumn{8}{|l|}{ Paper birch } \\
\hline Sawt imber & 11.6 & -- & -- & 2.3 & 6.9 & -- & 2.4 \\
\hline Poletimber & 51.8 & - & -- & -- & 4.6 & 31.1 & 16.1 \\
\hline Sapling \& seedling & 55.2 & -- & -- & -- & 9.3 & 18.4 & 27.5 \\
\hline All stands & 118.6 & -- & -- & 2.3 & 20.8 & 49.5 & 46.0 \\
\hline \multicolumn{8}{|l|}{ Exotic } \\
\hline Sawt imber & -- & -- & -- & -- & -- & -- & -- \\
\hline Poletimber & -- & -- & -- & -- & -- & - & -- \\
\hline Sapling \& seedling & 2.2 & -- & -- & - & 2.2 & - & -- \\
\hline All stands & 2.2 & -- & -- & -- & 2.2 & -- & -- \\
\hline Nonstocked & 32.8 & -- & -- & -- & -- & 14.1 & 18.7 \\
\hline \multicolumn{8}{|l|}{ All types } \\
\hline Sawt imber & 882.5 & -- & -- & 31.6 & 195.3 & 374.4 & 281.2 \\
\hline Poletimber & $1,152.1$ & -- & 4.4 & 47.9 & 207.4 & 575.8 & 316.6 \\
\hline Sapling \& seedling & 883.5 & -- & -- & 19.5 & 162.0 & 407.9 & 294.1 \\
\hline Nonstocked & 32.8 & -- & -- & -- & -- & 14.1 & 18.7 \\
\hline All stands & $2,950.9$ & -- & 4.4 & 99.0 & 564.7 & $1,372.2$ & 910.6 \\
\hline
\end{tabular}




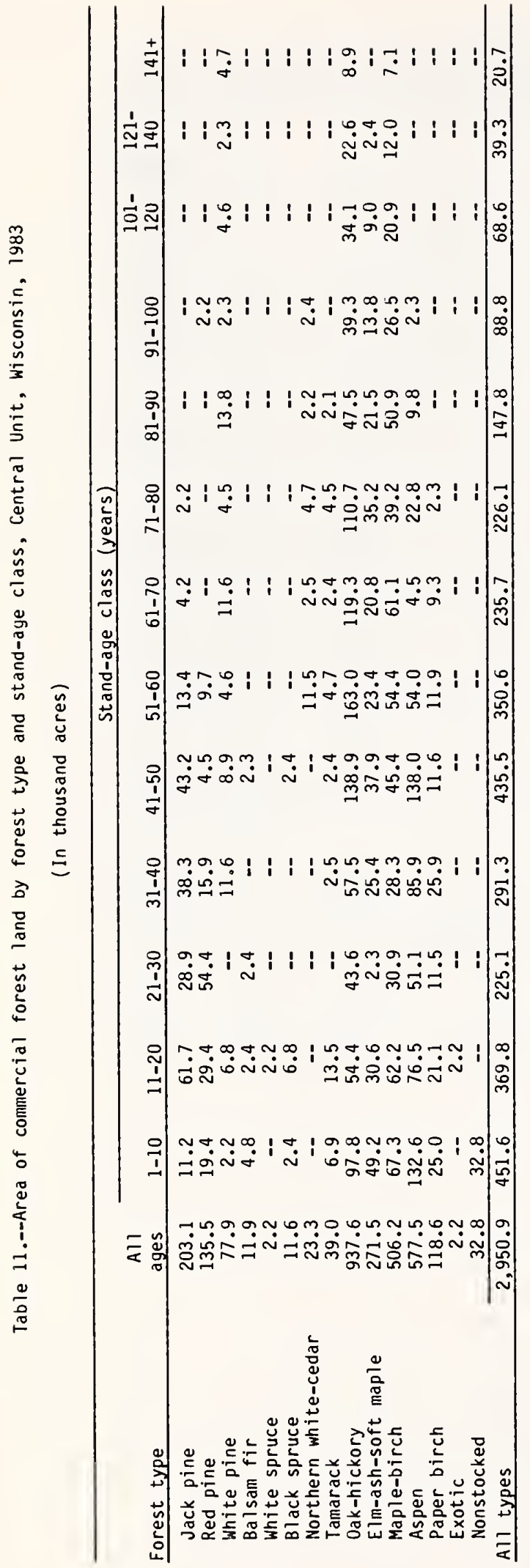

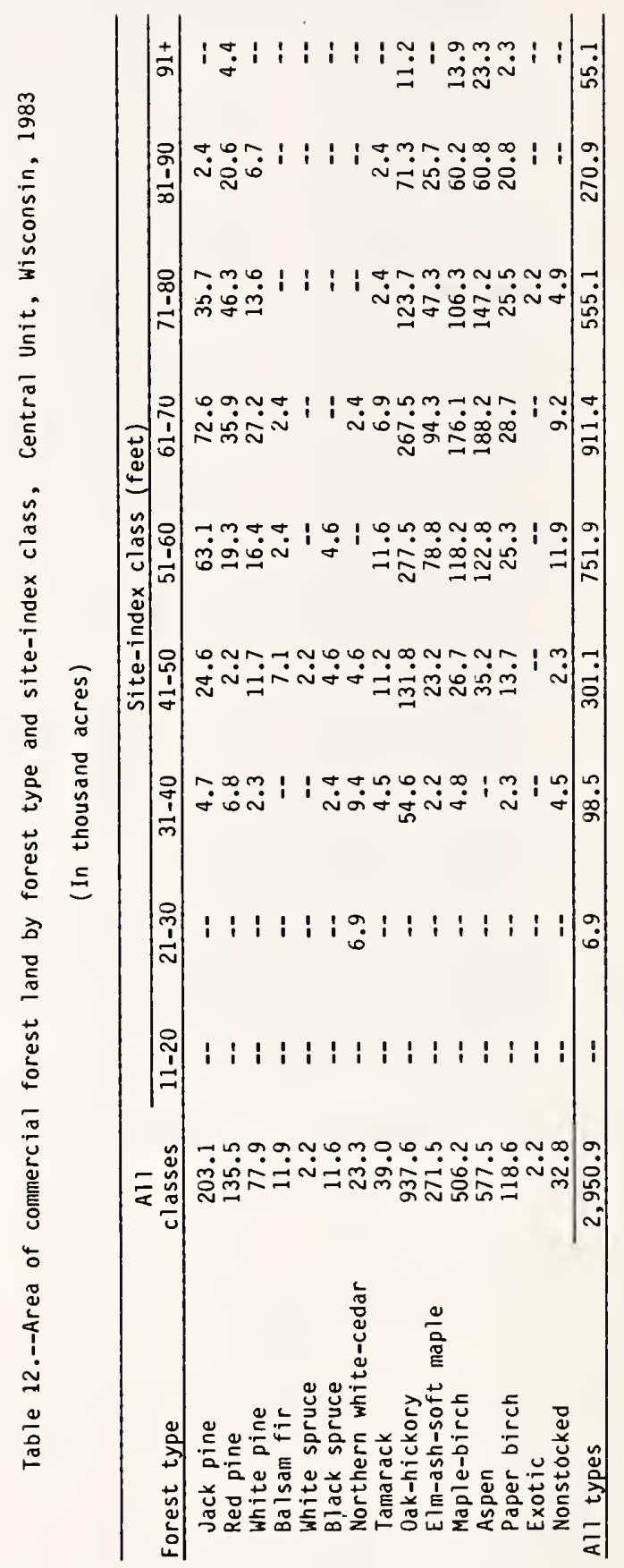




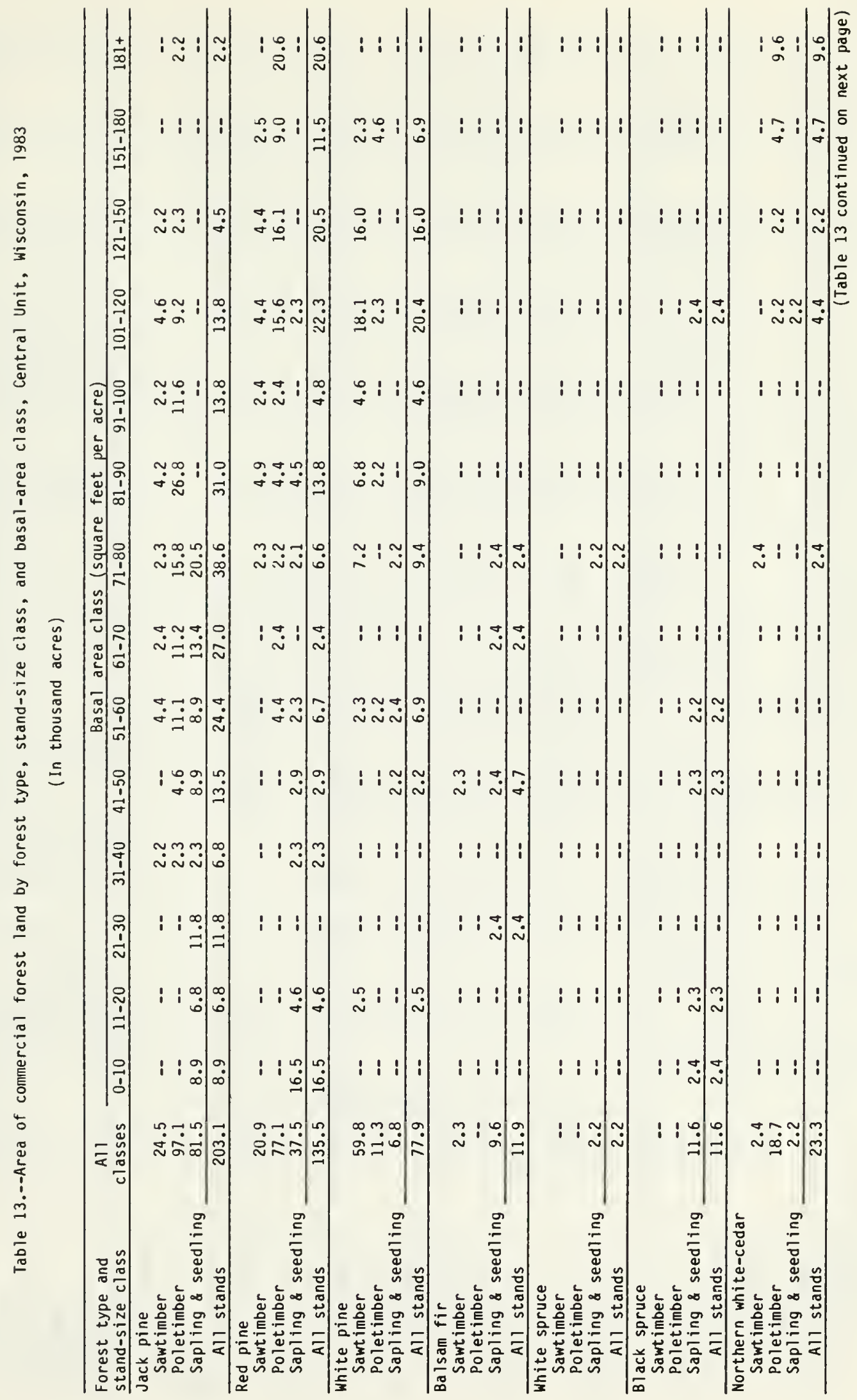




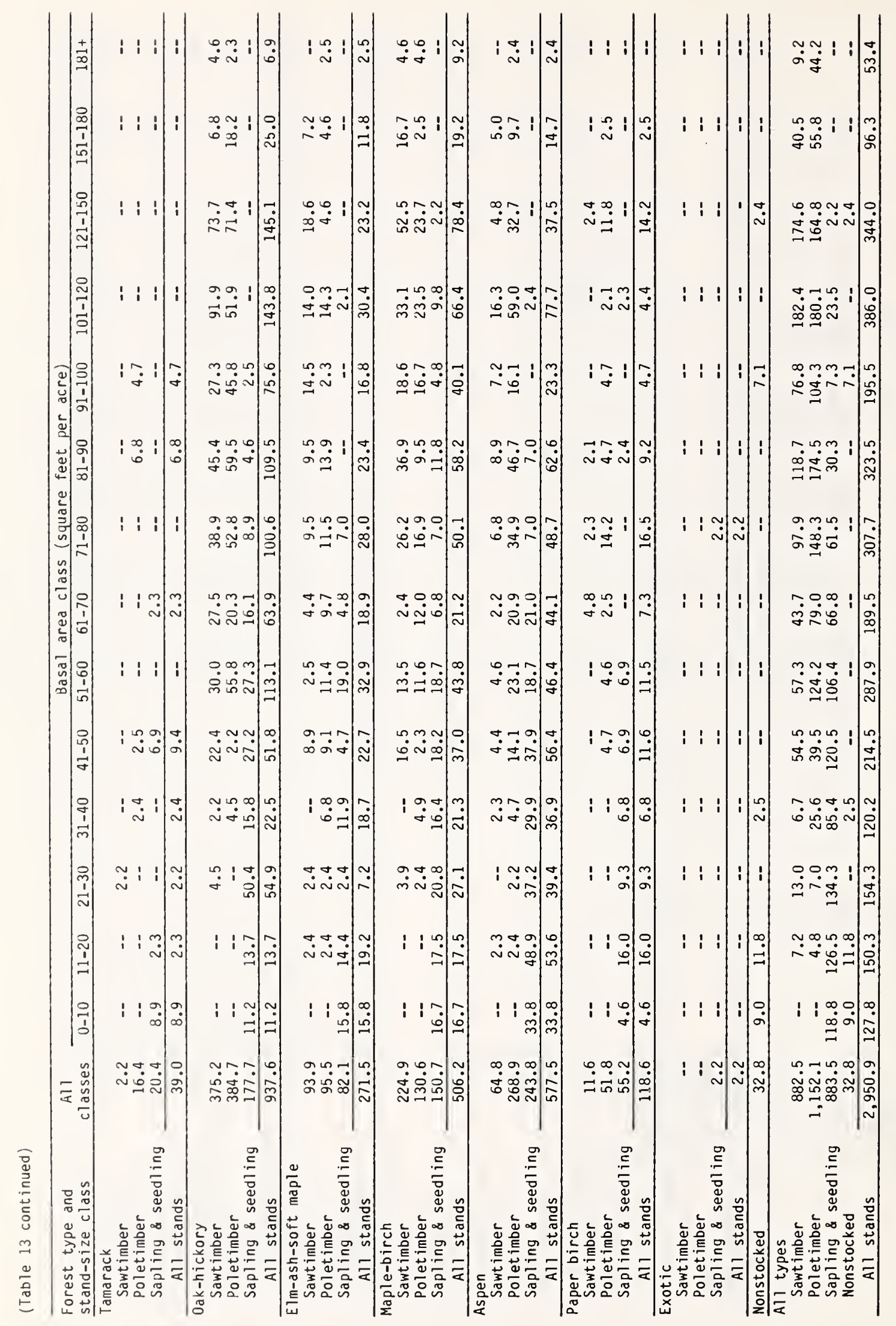




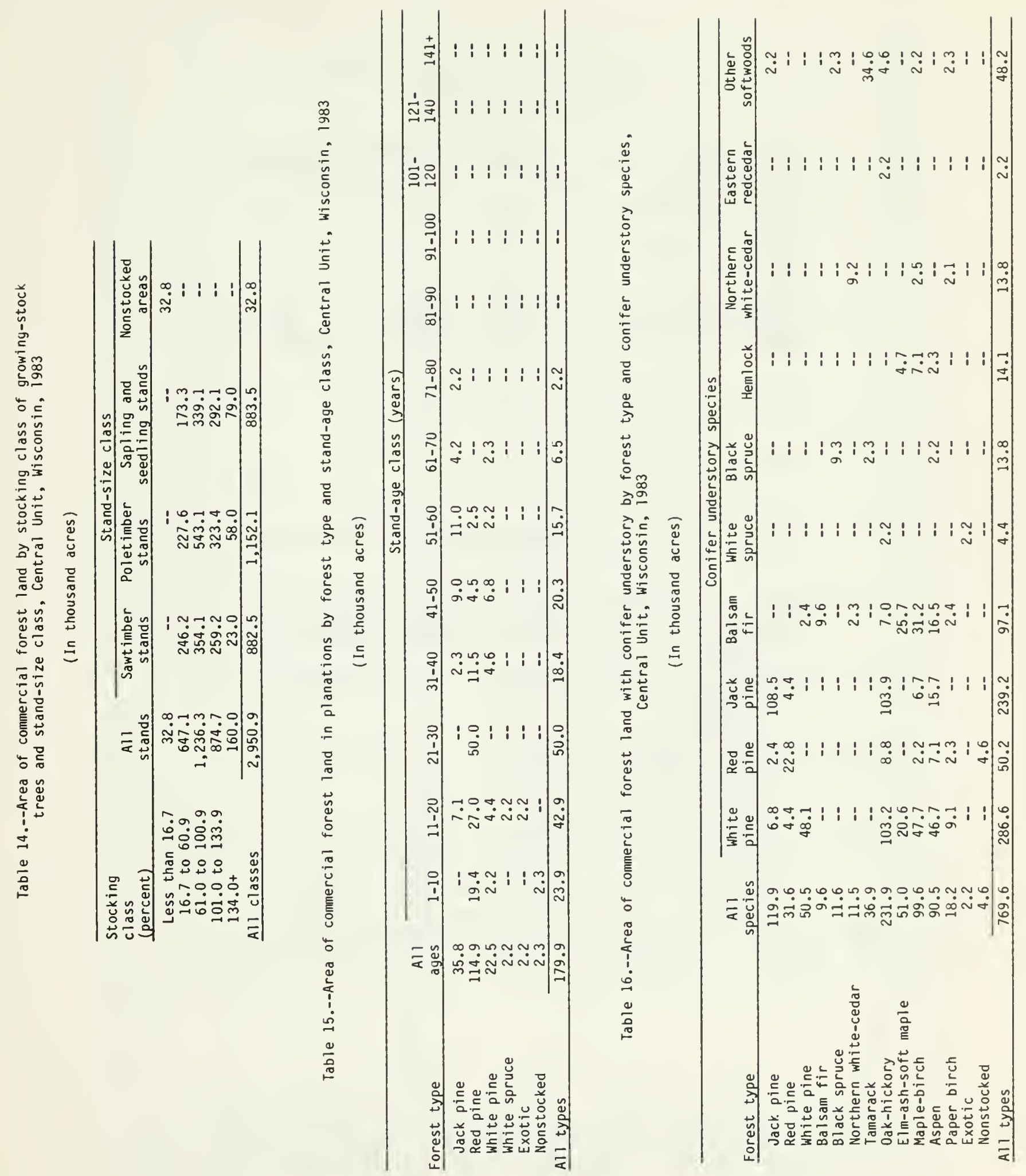


Table 17.--Area of noncominercial forest land by ownership class, Central Unit, Wisconsin, 1983

(In thousand acres)

\begin{tabular}{lccc}
\hline Ownership class & $\begin{array}{c}\text { All } \\
\text { areas }\end{array}$ & $\begin{array}{c}\text { Unproductive } \\
\text { areas }\end{array}$ & $\begin{array}{c}\text { Productive- } \\
\text { reserved areas }\end{array}$ \\
\hline National Forest & -- & -- & -- \\
Miscellaneous federal & 2.3 & -- & -- \\
State & 8.0 & -- & 3.9 \\
County and municipal & 3.9 & -- & -- \\
Indian & -- & -- & -- \\
Forest industry & -- & 7.1 & 2.3 \\
Farmer & 9.4 & -- & 4.4 \\
Misc. private-corp. & 4.4 & 12.1 & 11.5 \\
Misc. private-indiv. & 23.6 & 21.5 & 30.1 \\
Total & 51.6 & &
\end{tabular}

Table 18.--Area of noncommercial forest land by forest type, Central Unit, Wisconsin, 1983

(In thousand acres)

\begin{tabular}{lrrr}
\hline Forest type & $\begin{array}{c}\text { All } \\
\text { areas }\end{array}$ & $\begin{array}{c}\text { Unproductive } \\
\text { areas }\end{array}$ & $\begin{array}{c}\text { Productive- } \\
\text { reserved areas }\end{array}$ \\
\hline Jack pine & -- & -- & -- \\
Red pine & 11.3 & -- & 11.3 \\
White pine & -- & -- & -- \\
Balsam fir & -- & -- & -- \\
White spruce & -- & -- & -- \\
Black spruce & 2.4 & 2.4 & -- \\
Northern white-cedar & -- & -- & -- \\
Tamarack & -- & -- & -- \\
Oak-hickory & 4.8 & 2.3 & 2.5 \\
Elm-ash-soft maple & 12.8 & 7.3 & 5.5 \\
Maple-birch & 2.5 & 2.5 & -- \\
Aspen & 6.3 & 2.3 & 4.0 \\
Paper birch & 2.3 & 2.3 & -- \\
Exotic & 6.8 & -- & 6.8 \\
Nonstocked & 2.4 & 2.4 & -- \\
All types & 51.6 & 21.5 & 30.1 \\
\hline
\end{tabular}




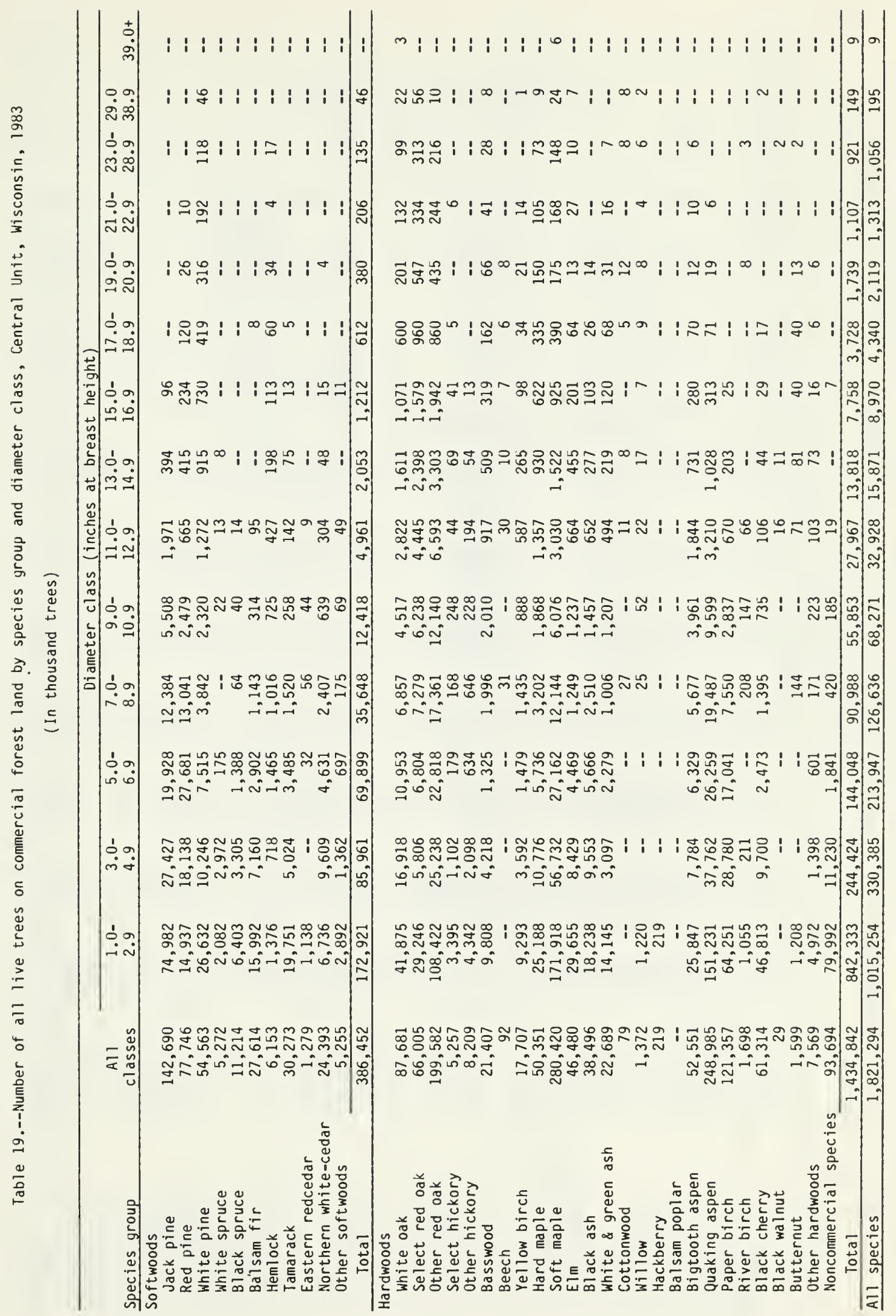




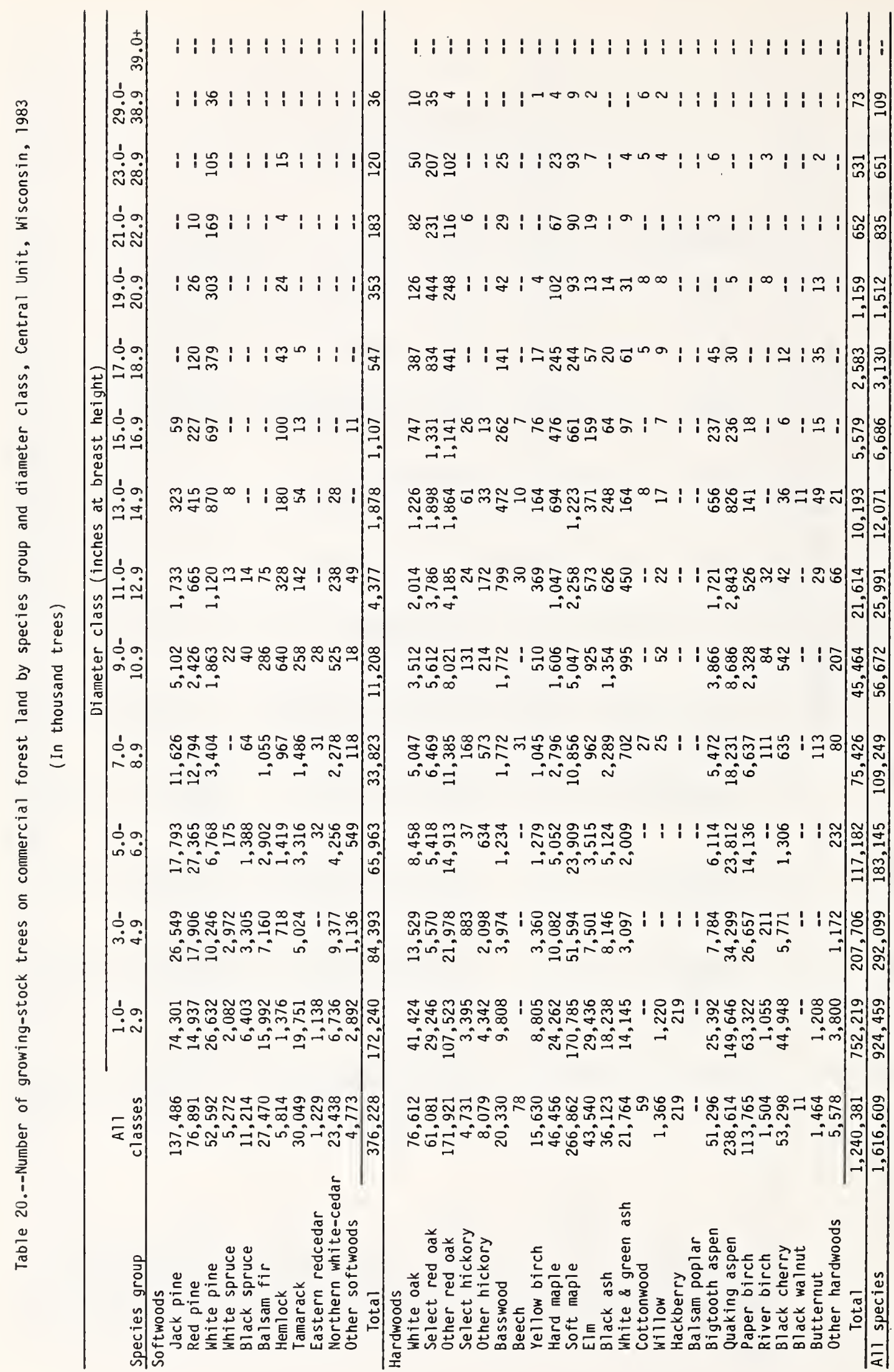


Table 21..-Net volume of growing stock on commercial forest land by species group, Central Unit, Wisconsin, 1968 and 1983

(In thousand cubic feet)

\begin{tabular}{|c|c|c|}
\hline Species group & $19681 /$ & 1983 \\
\hline \multicolumn{3}{|l|}{ Softwoods } \\
\hline Jack pine & 137,700 & 190,546 \\
\hline Red pine & 36,900 & 232,454 \\
\hline White pine & 103,700 & 172,290 \\
\hline White spruce & 700 & 905 \\
\hline Black spruce & 1,700 & 3,982 \\
\hline Balsam fir & 10,300 & 16,335 \\
\hline Hemlock & 27,800 & 26,895 \\
\hline Tamarack & 16,500 & 25,976 \\
\hline Eastern redcedar & 250 & 405 \\
\hline Northern white-cedar & 24,700 & 30,702 \\
\hline Other softwoods & 450 & 2,565 \\
\hline Total & 360,700 & 703,055 \\
\hline \multicolumn{3}{|l|}{ Hardwoods } \\
\hline White oak & 111,000 & 160,013 \\
\hline Select red oak & 249,200 & 336,908 \\
\hline Other red oak & 137,600 & 317,206 \\
\hline Select hickory & 2,800 & 5,344 \\
\hline other hickory & 6,200 & 11,836 \\
\hline Basswood & 53,100 & 75,883 \\
\hline Beech & 500 & 1,092 \\
\hline Yellow birch & 23,700 & 24,323 \\
\hline Hard maple & 78,600 & 115,891 \\
\hline Soft maple & 146,000 & 306,458 \\
\hline$E \operatorname{lm}$ & 105,600 & 43,125 \\
\hline Black ash & 40,400 & 63,807 \\
\hline White and green ash & 23,900 & 38,682 \\
\hline Cottonwood & - & 2,368 \\
\hline Willow & 2,400 & 3,034 \\
\hline Hackberry & - & - \\
\hline Balsam poplar & 100 & - \\
\hline Bigtooth aspen & 92,200 & 153,865 \\
\hline Quaking aspen & 225,200 & 351,029 \\
\hline Paper birch & 66,000 & 127,154 \\
\hline River birch & 3,400 & 2,706 \\
\hline Black cherry & 7,900 & 16,345 \\
\hline Black walnut & 200 & 220 \\
\hline Butternut & 2,900 & 4,880 \\
\hline Other hardwoods & 700 & 3,641 \\
\hline Total & $1,379,600$ & $2,165,810$ \\
\hline All species & $1,740,300$ & $2,868,865$ \\
\hline
\end{tabular}




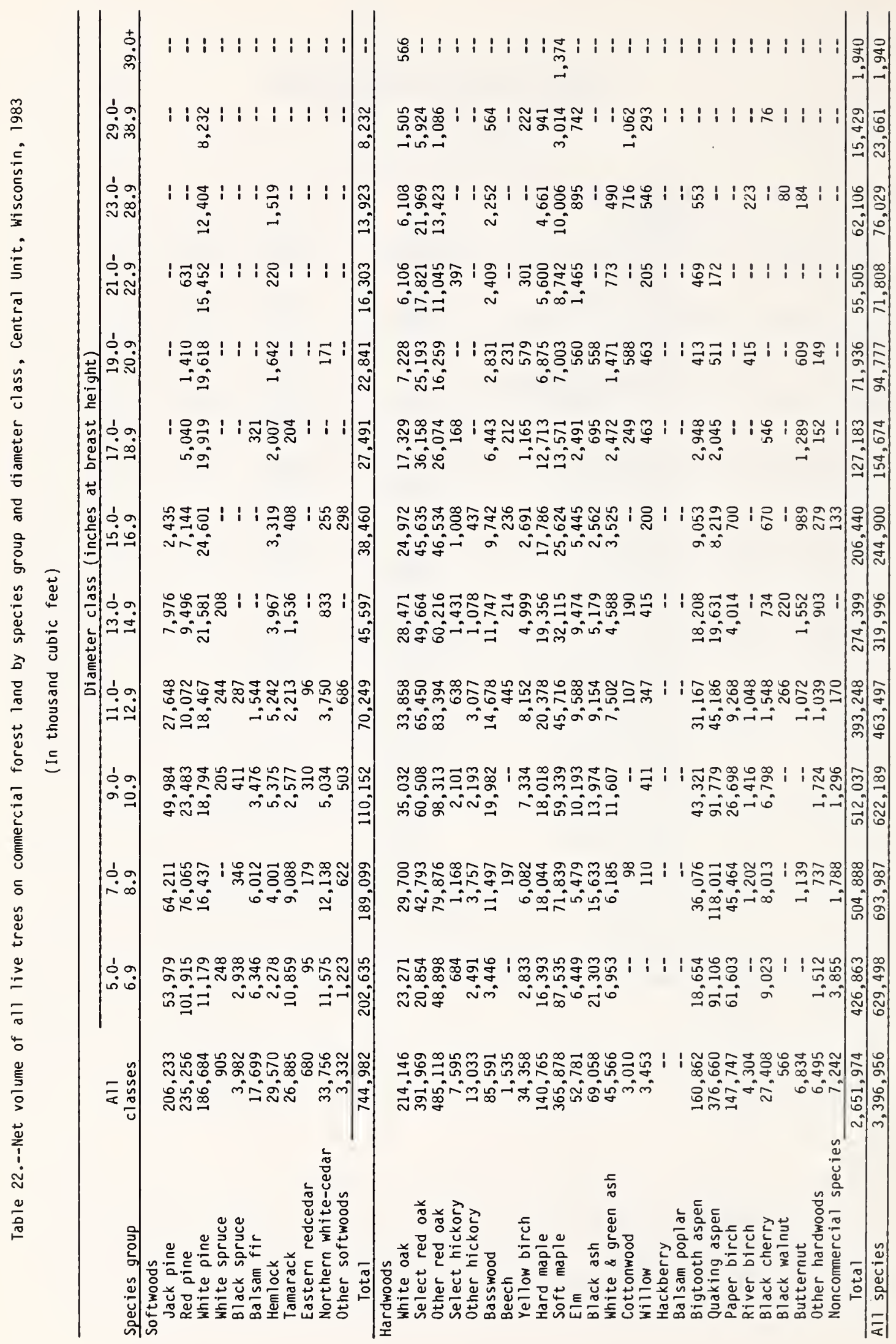


Table 23.--Net volume of timber on commercial forest land by class of

timber and softwoods and hardwoods, Central Unit, Wisconsin, 1983

(In thousand cubic feet)

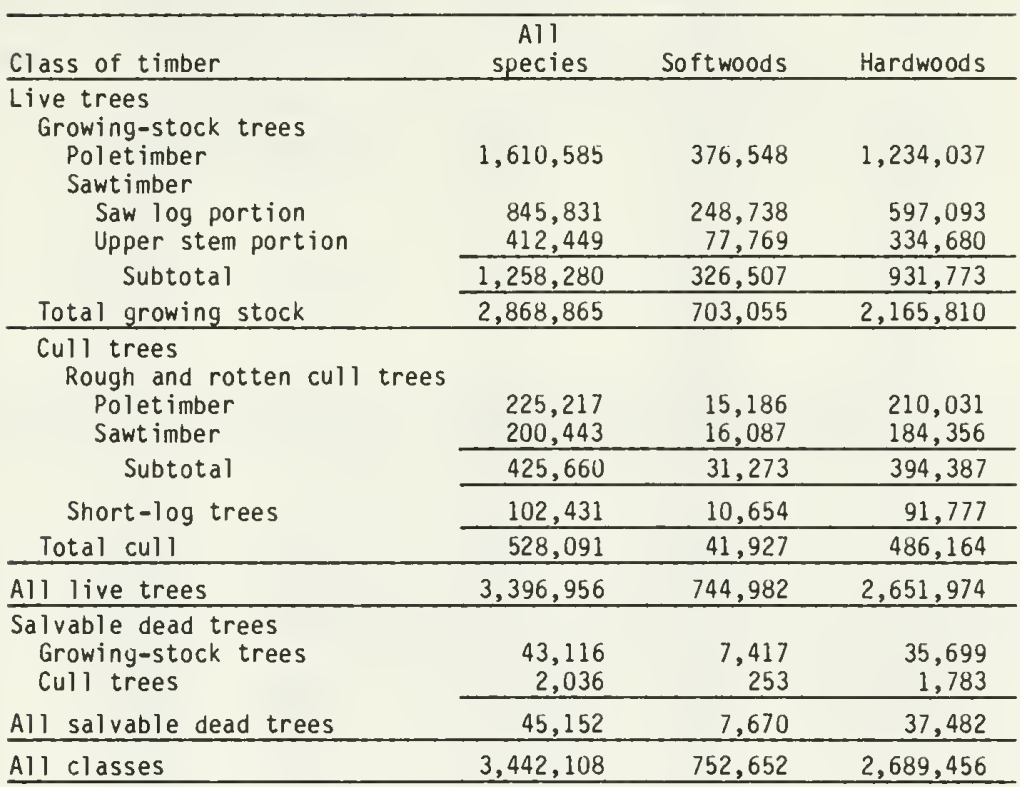


Table 24.--Net volume of all live trees by individual species, Central Unit, Wisconsin, 1983

\begin{tabular}{|c|c|c|c|c|c|c|c|}
\hline \multirow[b]{3}{*}{ Species } & \multirow{3}{*}{$\begin{array}{l}\text { Total } \\
\text { all live } \\
\end{array}$} & \multicolumn{3}{|c|}{ All live trees } & \multirow{3}{*}{$\begin{array}{c}\text { Total } \\
\text { saw log }\end{array}$} & \multirow{2}{*}{\multicolumn{2}{|c|}{ Saw $\log$ size trees }} \\
\hline & & \multirow{2}{*}{$\begin{array}{l}\text { Growing } \\
\text { stock }\end{array}$} & \multirow{2}{*}{$\begin{array}{c}\text { Short-log } \\
\text { cull }\end{array}$} & \multirow{2}{*}{$\begin{array}{l}\text { Rough and } \\
\text { rotten cull }\end{array}$} & & & \\
\hline & & & & & & Sawtimber & Short-log \\
\hline Softwoods & $-\cdots$ & -Thousand & ic feet- - & $-\cdots$ & $-\cdots-$ & Isand boarc & et $1 / \ldots$ \\
\hline Jack pine & 206,233 & 190,546 & 1,961 & 13,726 & 422,926 & 416,129 & 6,797 \\
\hline Red pine & 235,256 & 232,454 & 137 & 2,665 & 326,159 & 325,587 & 572 \\
\hline White pine & 186,684 & 172,290 & 6,945 & 7,449 & 795,158 & 772,302 & 22,856 \\
\hline White spruce & 905 & 905 & -- & -- & 3,147 & 3,147 & -- \\
\hline Black spruce & 3,982 & 3,982 & -- & -- & 3,038 & 3,038 & -- \\
\hline Balsam fir & 17,699 & 16,335 & -- & 1,364 & 18,838 & 18,838 & -- \\
\hline Hemlock & 29,570 & 26,895 & 641 & 2,034 & 89,779 & 88,210 & 1,569 \\
\hline Tamarack & 26,885 & 25,976 & 191 & 718 & 35,708 & 34,873 & 835 \\
\hline Eastern redcedar & 680 & 405 & -- & 275 & 1,272 & 1,272 & -- \\
\hline Northern white-cedar & 33,756 & 30,702 & 415 & 2,639 & 41,846 & 40,436 & 1,410 \\
\hline Scotch pine & 3,332 & 2,565 & 364 & 403 & 8,058 & 6,238 & 1,820 \\
\hline Total & 744,982 & 703,055 & 10,654 & 31,273 & $1,745,929$ & $1,710,070$ & 35,859 \\
\hline \multicolumn{8}{|l|}{ Hardwoods } \\
\hline White oak & 167,030 & 125,339 & 9,334 & 32,357 & 388,649 & 363,912 & 24,737 \\
\hline Swamp white oak & 6,971 & 5,138 & 509 & 1,324 & 19,617 & 18,313 & 1,304 \\
\hline Bur oak & 40,145 & 29,536 & 3,234 & 7,375 & 99,020 & 90,432 & 8,588 \\
\hline Northern red oak & 391,969 & 336,908 & 14,390 & 40,671 & $1,138,966$ & $1,106,582$ & 32,384 \\
\hline Northern pin oak & 172,808 & 106,847 & 9,774 & 56,187 & 268,012 & 245,829 & 22,183 \\
\hline Black oak & 312,310 & 210,359 & 22,245 & 79,706 & 577,972 & 527,011 & 50,961 \\
\hline Shagbark hickory & 7,595 & 5,344 & 429 & 1,822 & 15,229 & 13,982 & 1,247 \\
\hline Bitternut hickory & 13,033 & 11,836 & 402 & 795 & 20,819 & 19,733 & 1,086 \\
\hline American basswood & 85,591 & 75,883 & 1,704 & 8,004 & 216,903 & 213,198 & 3,705 \\
\hline Beech & 1,535 & 1,092 & $=$ & 443 & 4,749 & 4,749 & - \\
\hline Yellow birch & 34,358 & 24,323 & 1,527 & 8,508 & 58,330 & 54,922 & 3,408 \\
\hline Sugar maple & 140,765 & 115,891 & 6,855 & 18,019 & 358,295 & 341,476 & 16,819 \\
\hline Red maple & 328,384 & 279,262 & 9,220 & 39,902 & 496,781 & 472,281 & 24,500 \\
\hline Silver maple & 37,494 & 27,196 & 3,458 & 6,840 & 100,048 & 91,158 & 8,890 \\
\hline American elm & 45,306 & 36,642 & 1,822 & 6,842 & 99,168 & 94,504 & 4,664 \\
\hline Slippery elm & 2,988 & 2,319 & - & 669 & 5,123 & 5,123 & - \\
\hline Rock elm & 4,487 & 4,164 & $-\infty$ & 323 & 9,885 & 9,885 & -- \\
\hline Black ash & 69,058 & 63,807 & 542 & 4,709 & 101,612 & 100,226 & 1,386 \\
\hline White ash & 28,670 & 24,738 & 954 & 2,978 & 50,553 & 48,316 & 2,237 \\
\hline Green ash & 16,896 & 13,944 & -- & 2,952 & 48,420 & 48,420 & -- \\
\hline Eastern cottonwood & 3,010 & 2,368 & 188 & 454 & 10,747 & 10,173 & 574 \\
\hline Black willow & 3,453 & 3,034 & 214 & 205 & 11,517 & 10,825 & 692 \\
\hline Hackberry & -- & -- & -- & -- & -- & -- & -- \\
\hline Balsam poplar & -- & -- & -- & -- & -- & -- & -- \\
\hline Bigtooth aspen & 160,862 & 153,865 & 1,187 & 5,810 & 268,119 & 266,184 & 1,935 \\
\hline Quaking aspen & 376,660 & 351,029 & 1,408 & 24,223 & 331,498 & 328,348 & 3,150 \\
\hline Paper birch & 147,747 & 127,154 & 798 & 19,795 & 57,513 & 55,304 & 2,209 \\
\hline River birch & 4,304 & 2,706 & -- & 1,598 & 5,566 & 5,566 & -- \\
\hline Black cherry & 27,408 & 16,345 & 357 & 10,706 & 11,999 & 10,963 & 1,036 \\
\hline Black walnut & 566 & 220 & -- & 346 & 1,275 & $1,27 b$ & -- \\
\hline Butternut & 6,834 & 4,880 & 768 & 1,186 & 23,341 & 21,233 & 2,108 \\
\hline Boxelder & 2,715 & 1,008 & 97 & 1,610 & 3,105 & 2,742 & 363 \\
\hline Black locust & 3,780 & 2,633 & 361 & 786 & 4,269 & 3,001 & 1,268 \\
\hline Total & $2,644,732$ & $2,165,810$ & 91,777 & 387,145 & $4,807,100$ & $4,585,666$ & 221,434 \\
\hline All species $2 /$ & $3,389,714$ & $2,868,865$ & 102,431 & 418,418 & $6,553,029$ & $6,295,736$ & 257,293 \\
\hline
\end{tabular}

$1 /$ International $1 / 4$-inch rule.

2/ These totals do not include volume for noncommercial species. Volumes for individual noncommercial species are found in Table 25 . 
Table 25.--Net volume of noncommercial species on commercial forest land by individual species, Central Unit, Wisconsin, 1983

(In thousand cubic feet)

\begin{tabular}{lc}
\hline Species & Cull volume \\
\hline Ailanthus & 576 \\
American hornbeam & 360 \\
Hawthorn & 1,053 \\
Eastern hophornbeam & 4,837 \\
Chokecherry & 416 \\
All species & 7,242 \\
\hline
\end{tabular}

Table 26.--Net volume of growing stock on commercial forest land by species group and county, Central Unit, Wisconsin, 1983

(In thousand cubic feet)

\begin{tabular}{|c|c|c|c|c|c|c|c|c|c|}
\hline \multirow[b]{2}{*}{ Species group } & \multirow{2}{*}{$\begin{array}{c}\text { All } \\
\text { counties }\end{array}$} & \multicolumn{7}{|c|}{ County } & \multirow[b]{2}{*}{ Marquette } \\
\hline & & Adams & Chippewa & Clark & Eau Claire & Jackson & Juneau & Marathon & \\
\hline \multicolumn{10}{|l|}{ Softwoods } \\
\hline Jack pine & 190,546 & 36,638 & 2,511 & 3,282 & 9,405 & 52,358 & 42,794 & 412 & 1,824 \\
\hline Red pine & 232,454 & 40,247 & 5,099 & 10,568 & 23,289 & 32,066 & 21,307 & 2,862 & 10,341 \\
\hline White pine & 172,290 & 11,283 & 10,057 & 13,226 & 7,054 & 21,183 & 9,532 & 13,719 & 8,196 \\
\hline White spruce & 905 & -- & 449 & -- & -- & -- & $\cdots$ & 208 & -- \\
\hline Black spruce & 3,982 & -- & 175 & 1,614 & -- & -- & -- & 938 & -- \\
\hline Balsam fir & 16,335 & - & -- & -- & -- & -- & -- & 8,756 & -- \\
\hline Heml ock & 26,895 & -- & 88 & -- & -- & -- & -- & 16,718 & -- \\
\hline Tamarack & 25,976 & 312 & 3,834 & -- & -- & 1,722 & 534 & 1,974 & 3,779 \\
\hline Eastern redcedar & 405 & -- & -- & -- & -- & 214 & 95 & -- & 96 \\
\hline Northern white-cedar & 30,702 & -- & -- & -- & $=$ & -- & - & 6,658 & -- \\
\hline Other softwoods & 2,565 & - & -- & -- & -- & 822 & -- & - & 846 \\
\hline Total & 703,055 & 88,480 & 22,213 & 28,690 & 39,748 & 108,365 & 74,262 & 52,245 & 25,082 \\
\hline \multicolumn{10}{|l|}{ Hardwoods } \\
\hline White oak & 160,013 & 4,685 & 11,520 & 21,772 & 14,109 & 21,656 & 12,824 & 2,478 & 9,525 \\
\hline Select red oak & 336,908 & 7,755 & 25,414 & 39,938 & 16,066 & 63,963 & 29,203 & 34,127 & 5,393 \\
\hline Other red oak & 317,206 & 43,498 & 7,205 & 5,095 & 36,201 & 52,208 & 46,527 & 1,253 & 16,023 \\
\hline Select hickory & 5,344 & -- & -- & -- & -- & 826 & 177 & -- & 398 \\
\hline other hickory & 11,836 & -- & 4,101 & 532 & -- & -- & 144 & 2,255 & -- \\
\hline Basswood & 75,883 & 637 & 15,470 & 11,172 & 4,073 & 106 & 2,102 & 24,002 & 1,280 \\
\hline Beech & 1,092 & -- & -- & -- & -- & -- & - & -- & -- \\
\hline Yellow birch & 24,323 & -- & 1,358 & 1,092 & -- & -- & -- & 18,586 & -- \\
\hline Hard maple & 115,891 & -- & 12,753 & 11,129 & 1,692 & -- & 2,226 & 63,910 & -- \\
\hline Soft maple & 306,458 & 4,416 & 22,068 & 43,128 & 11,853 & 29,243 & 12,635 & 69,527 & 2,977 \\
\hline Elm & 43,125 & 333 & 7,909 & 5,305 & 334 & 1,042 & 1,075 & 13,653 & 146 \\
\hline Black ash & 63,807 & 727 & 14,586 & 8,869 & 629 & -- & 364 & 10,371 & 1,454 \\
\hline White \& green ash & 38,682 & - & 6,085 & 3,781 & 274 & 316 & 1,387 & 11,330 & 1,411 \\
\hline Cottonwood & 2,368 & 253 & -- & $\rightarrow$ & -- & 552 & 393 & - & 249 \\
\hline Willow & 3,034 & 675 & -- & - & -- & 293 & 382 & -- & 433 \\
\hline Hackberry & -- & -- & -- & -- & - & -- & -- & -- & -- \\
\hline Balsam poplar & -- & -- & -- & -- & -- & - & -- & -- & -- \\
\hline Bigtooth aspen & 153,865 & 3,467 & 21,179 & 26,347 & 5,675 & 28,832 & 6,752 & 17,031 & -- \\
\hline Quaking aspen & 351,029 & 11,083 & 30,744 & 88,189 & 28,532 & 29,235 & 25,040 & 50,195 & 3,132 \\
\hline Paper birch & 127,154 & 1,736 & 18,041 & 18,430 & 8,908 & 12,988 & 7,776 & 18,747 & 537 \\
\hline River birch & $2,7 \cup 6$ & -- & -- & -- & 669 & 859 & 587 & -- & -- \\
\hline Black cherry & 16,345 & 563 & 555 & 961 & 1,366 & 1,492 & 1,032 & 2,049 & 173 \\
\hline Black walnut & 220 & -- & -- & -- & -- & -- & 220 & -- & -- \\
\hline Butternut & 4,880 & -- & 261 & 598 & -- & -- & 965 & 504 & -- \\
\hline Other hardwoods & 3,641 & - & -- & -- & -- & 240 & -- & -- & 114 \\
\hline Total & $2,165,810$ & 79,828 & 199,249 & 286,338 & 130,381 & 243,851 & 151,811 & 340,018 & 43,245 \\
\hline All species & $2,868,865$ & 168,308 & 221,462 & 315,028 & 170,129 & 352,216 & 226,073 & 392,263 & 68,327 \\
\hline
\end{tabular}


(Table 26 continued)

\begin{tabular}{lrrrrr}
\hline & \multicolumn{5}{c}{ County } \\
\cline { 2 - 6 } Species group & Monroe & Portage & Waupaca & Waushara & Wood \\
\hline Softwoods & & & & & \\
Jack pine & 16,465 & 3,756 & -- & 8,283 & 12,818 \\
Red pine & 1,898 & 26,602 & 17,976 & 38,917 & 1,282 \\
White pine & 15,534 & 12,894 & 20,445 & 15,789 & 13,378 \\
White spruce & -- & -- & 96 & -- & 152 \\
Black spruce & -- & 525 & 411 & -- & 319 \\
Balsam fir & -- & 66 & 7,513 & -- & -- \\
Hemlock & -- & 1,962 & 7,982 & -- & 145 \\
Tamarack & -- & 3,379 & 5,325 & 5,117 & -- \\
Eastern redcedar & -- & -- & -- & -- & -- \\
Northern white-cedaryyyyyy & -- & 6,975 & 14,995 & 2,074 & -- \\
Other softwoods & -- & -- & -- & 897 & -- \\
\hline Total & 33,897 & 56,159 & 74,743 & 71,077 & 28,094 \\
\hline Hardwoods & & & & & \\
White oak & 13,366 & 10,187 & 8,561 & 15,888 & 13,442 \\
Select red oak & 49,727 & 15,040 & 21,145 & 6,326 & 22,811 \\
Other red oak & 33,067 & 21,590 & 8,485 & 34,437 & 11,617 \\
Select hickory & 2,398 & -- & 207 & 1,338 & -- \\
Other hickory & 340 & 695 & 3,769 & -- & -- \\
Basswood & 1,206 & 3,697 & 7,924 & 246 & 3,968 \\
Beech & -- & -- & 1,092 & -- & -- \\
Yellow birch & -- & 392 & 2,658 & -- & 237 \\
Hard maple & 2,829 & 3,804 & 14,030 & -- & 3,518 \\
Soft maple & 15,320 & 15,902 & 42,695 & 6,148 & 30,546 \\
Elm & 2,058 & 1,581 & 7,411 & 1,299 & 979 \\
Black ash & 3,874 & 5,338 & 13,960 & 1,638 & 1,997 \\
White \& green ash & 1,494 & 1,011 & 9,671 & 1,452 & 470 \\
Cottonwood & 331 & -- & --- & 590 & -- \\
Willow & -- & -- & 1,251 & -- & -- \\
Hackberry & -- & -- & --- & -- & -- \\
Balsam poplar & -- & -- & -- & -- & -- \\
Bigtoooth aspen & 12,271 & 5,499 & 9,925 & 7,428 & 9,459 \\
Quaking aspen & 8,231 & 19,683 & 8,538 & 1,722 & 46,705 \\
Paper birch & 15,826 & 5,369 & 7,870 & 5,561 & 5,365 \\
River birch & -- & -- & -- & -- & 591 \\
Black cherry & 2,585 & 2,448 & 1,916 & 893 & 312 \\
Black walnut & -- & -- & -- & --- & -- \\
Butternut & 1,564 & -- & 823 & 165 & -- \\
Other hardwoods & -- & -- & 2,893 & 394 & -- \\
$\quad$ Total & 166,487 & 112,236 & 174,824 & 85,525 & 152,017 \\
\hline All species & 200,384 & 168,395 & 249,567 & 156,602 & 180,111 \\
\hline
\end{tabular}


Table 27.--Net volume of sawtimber on commercial forest land by species group and county, Central Unit, Wisconsin, 1983

(In thousand board feet) 1 '

\begin{tabular}{|c|c|c|c|c|c|c|c|c|c|}
\hline \multirow[b]{2}{*}{ Species group } & \multirow{2}{*}{$\begin{array}{c}\text { All } \\
\text { counties }\end{array}$} & \multicolumn{8}{|c|}{ County } \\
\hline & & Adams & Chippewa & Clark & Eau Claire & Jackson & Juneau & Marathon & Marquette \\
\hline \multicolumn{10}{|l|}{ Softwoods } \\
\hline Jack pine & 416,129 & 81,546 & 7,123 & 8,603 & 14,769 & 110,118 & 82,401 & 2,187 & 4,592 \\
\hline Red pine & 325,587 & 20,487 & 28,031 & 46,413 & 7,717 & 53,586 & 44,733 & 6,570 & -- \\
\hline White pine & 772,302 & 35,080 & 52,459 & 72,588 & 36,903 & 89,217 & 40,323 & 70,183 & 29,024 \\
\hline White spruce & 3,147 & -- & 2,082 & -- & -- & -- & -- & 1,065 & -- \\
\hline Black spruce & 3,038 & -- & -- & - & -- & -- & -- & 1,390 & -- \\
\hline Balsam fir & 18,838 & -- & -- & -- & -- & -- & -- & 10,798 & -- \\
\hline Heml ock & 88,210 & -- & -- & -- & -- & -- & -- & 55,025 & -- \\
\hline Tamarack & 34,873 & 1,699 & -- & -- & -- & -- & -- & 933 & 5,376 \\
\hline Eastern redcedar & 1,272 & -- & -- & -- & -- & 1,272 & -- & -- & -- \\
\hline Northern white-cedar & 40,436 & -- & -- & -- & -- & -- & -- & 10,914 & -- \\
\hline Other softwoods & 6,238 & -- & -- & 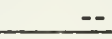 & -- & 4,573 & -- & -- & 892 \\
\hline Total & $1,710,070$ & 138,812 & 89,695 & 127,604 & 59,389 & 258,766 & 167,457 & 159,065 & 39,884 \\
\hline \multicolumn{10}{|l|}{ Hardwoods } \\
\hline White oak & 472,657 & 8,980 & 28,864 & 58,994 & 31,210 & 44,748 & 42,910 & 10,372 & 42,287 \\
\hline Select red oak & $, 106,582$ & 24,656 & 83,878 & 115,347 & 54,353 & 207,378 & 87,423 & 100,493 & 17,536 \\
\hline Other red oak & 772,840 & 82,503 & 23,389 & 7,627 & 66,530 & 125,553 & 112,975 & 5,539 & 65,354 \\
\hline Select hickory & 13,982 & -- & -- & -. & -. & 3,483 & 861 & - & 1,483 \\
\hline Other hickory & 19,733 & -- & 6,513 & 1,275 & -- & -- & -- & 3,869 & -- \\
\hline Basswood & 213,198 & 2,096 & 48,342 & 33,496 & 5,165 & -- & 10,340 & 59,695 & 3,653 \\
\hline Beech & 4,749 & - & -- & -- & -- & -- & -- & -- & -- \\
\hline Yellow birch & 54,922 & -- & 2,975 & -- & -- & -- & -- & 47,976 & -- \\
\hline Hard maple & 341,476 & -- & 33,183 & 34,654 & 1,387 & -- & 11,438 & 184,487 & -- \\
\hline Soft maple & 563,439 & 8,226 & 26,114 & 46,804 & 14,149 & 46,892 & 25,134 & 150,477 & 10,446 \\
\hline Elm & 109,512 & 1,431 & 16,087 & 14,081 & 1,129 & 606 & 4,498 & 35,553 & 693 \\
\hline Black ash & 100,226 & 2,758 & 16,751 & 13,820 & -- & -- & 2,462 & 1,504 & 2,691 \\
\hline White \& green ash & 96,736 & & 8,565 & 2,056 & -- & 1,566 & 5,089 & 29,592 & 2,574 \\
\hline Cottonwood & 10,173 & 1,132 & -- & -- & -- & 2,557 & 1,810 & -- & 1,078 \\
\hline Willow & 10,825 & 2,278 & -- & -- & -- & 1,345 & -- & -- & 1,855 \\
\hline Hackberry & -- & -- & -- & -- & -- & -- & -- & -- & -- \\
\hline Balsam poplar & -- & -- & -- & -- & -- & -- & -- & -- & -- \\
\hline Bigtooth aspen & 266,184 & 4,318 & 52,529 & 25,661 & 15,443 & 38,950 & 13,636 & 27,668 & -- \\
\hline Quaking aspen & 328,348 & 11,461 & 38,966 & 92,782 & 25,549 & 20,187 & 16,898 & 65,137 & 4,547 \\
\hline Paper birch & 55,304 & -- & 9,178 & 4,060 & 852 & 4,678 & 2,097 & 5,421 & - \\
\hline River birch & 5,566 & -- & -- & -- & 1,549 & 2,070 & 1,010 & -- & -- \\
\hline Bl ack cherry & 10,963 & 1,029 & -- & -- & -- & -- & 1,156 & 3,890 & -- \\
\hline Black walnut & 1,275 & -- & -- & $=$ & -- & -- & 1,275 & & -- \\
\hline Butternut & 21,233 & -- & 1,348 & 3,258 & -- & -- & 3,413 & 1,147 & -- \\
\hline Other hardwoods & 5,743 & -- & -- & -. & -- & -- & -- & -- & $-\infty$ \\
\hline Total & $4,585,666$ & 150,868 & 396,682 & 453,915 & 217,316 & 500,013 & 344,425 & 732,820 & 154,197 \\
\hline All species & $6,295,736$ & 289,680 & 486,377 & 581,519 & 276,705 & 758,779 & 511,882 & 891,885 & 194,081 \\
\hline
\end{tabular}

1/ International $1 / 4$-inch rule.

(Table 27 continued on next page) 
(Table 27 continued)

\begin{tabular}{|c|c|c|c|c|c|}
\hline \multirow[b]{2}{*}{ Species group } & \multicolumn{5}{|c|}{ County } \\
\hline & Monroe & Portage & Waupaca & Waushara & Wood \\
\hline \multicolumn{6}{|l|}{ Softwoods } \\
\hline Jack pine & 43,385 & 5,910 & -- & 24,180 & 31,315 \\
\hline Red pine & 6,682 & 40,259 & 33,205 & 30,491 & 7,413 \\
\hline White pine & 71,444 & 61,914 & 95,561 & 58,355 & 59,251 \\
\hline White spruce & -- & -- & -- & -- & -- \\
\hline Black spruce & -- & -- & 1,648 & -- & -- \\
\hline Balsam fir & -- & -- & 8,040 & -- & -- \\
\hline Hem lock & -- & 3,740 & 28,951 & -- & 494 \\
\hline tamarack & -- & 8,854 & 4,035 & 13,976 & -- \\
\hline Eastern redcedar & -- & -- & & -- & -- \\
\hline Northern white-cedar & -- & 11,385 & 16,681 & 1,456 & -- \\
\hline other softwoods & -- & - & -- & 773 & -- \\
\hline Total & 121,511 & 132,062 & 188,121 & 129,231 & 98,473 \\
\hline \multicolumn{6}{|l|}{ Hardwoods } \\
\hline White oak & 47,037 & 37,875 & 30,892 & 40,582 & 47,906 \\
\hline Select red oak & 174,869 & 52,716 & 85,555 & 12,854 & 89,524 \\
\hline Other red oak & 72,329 & 68,644 & 25,148 & 88,274 & 28,975 \\
\hline Select hickory & 5,170 & - & 985 & 2,000 & - \\
\hline other hickory & 869 & 2,718 & 4,489 & -- & -- \\
\hline Basswood & 3,291 & 4,064 & 30,449 & 1,189 & 11,418 \\
\hline Beech & - & - & 4,749 & - & - \\
\hline Yellow birch & -- & -- & 2,969 & -- & 1,002 \\
\hline Hard maple & 9,750 & 5,235 & 53,984 & -- & 7,358 \\
\hline Soft maple & 23,186 & 34,865 & 108,684 & 15,502 & 52,960 \\
\hline Elm & 6,343 & 1,643 & 20,803 & 3,254 & 3,391 \\
\hline Black ash & 18,751 & 10,022 & 24,649 & 1,308 & 5,510 \\
\hline White \& green ash & 2,527 & 4,224 & 37,983 & 1,535 & 1,025 \\
\hline Cottonwood & 1,065 & -- & - & 2,531 & -- \\
\hline Willow & - & -- & 5,347 & - & - \\
\hline Hackberry & -- & -- & -- & -- & -- \\
\hline Balsam poplar & -- & -- & -- & -- & - \\
\hline Bigtooth aspen & 29,467 & 12,713 & 25,293 & 8,962 & 11,544 \\
\hline Quaking aspen & 3,227 & 15,535 & 1,299 & 778 & 31,982 \\
\hline Paper birch & 9,490 & 6,680 & 7,110 & 3,684 & 2,054 \\
\hline River birch & -- & -- & $\ldots$ & -- & 937 \\
\hline Black cherry & 3,537 & 1,351 & -- & -- & -- \\
\hline Black walnut & - & -- & -- & & - \\
\hline Butternut & 6,529 & -- & 4,476 & 1,062 & -- \\
\hline Other hardwoods & - & - & 5,743 & -- & $=-$ \\
\hline Total & 417,437 & 258,285 & 480,607 & 183,515 & 295,586 \\
\hline Al1 species & 538,948 & 390,347 & 668,728 & 312,746 & 394,059 \\
\hline
\end{tabular}




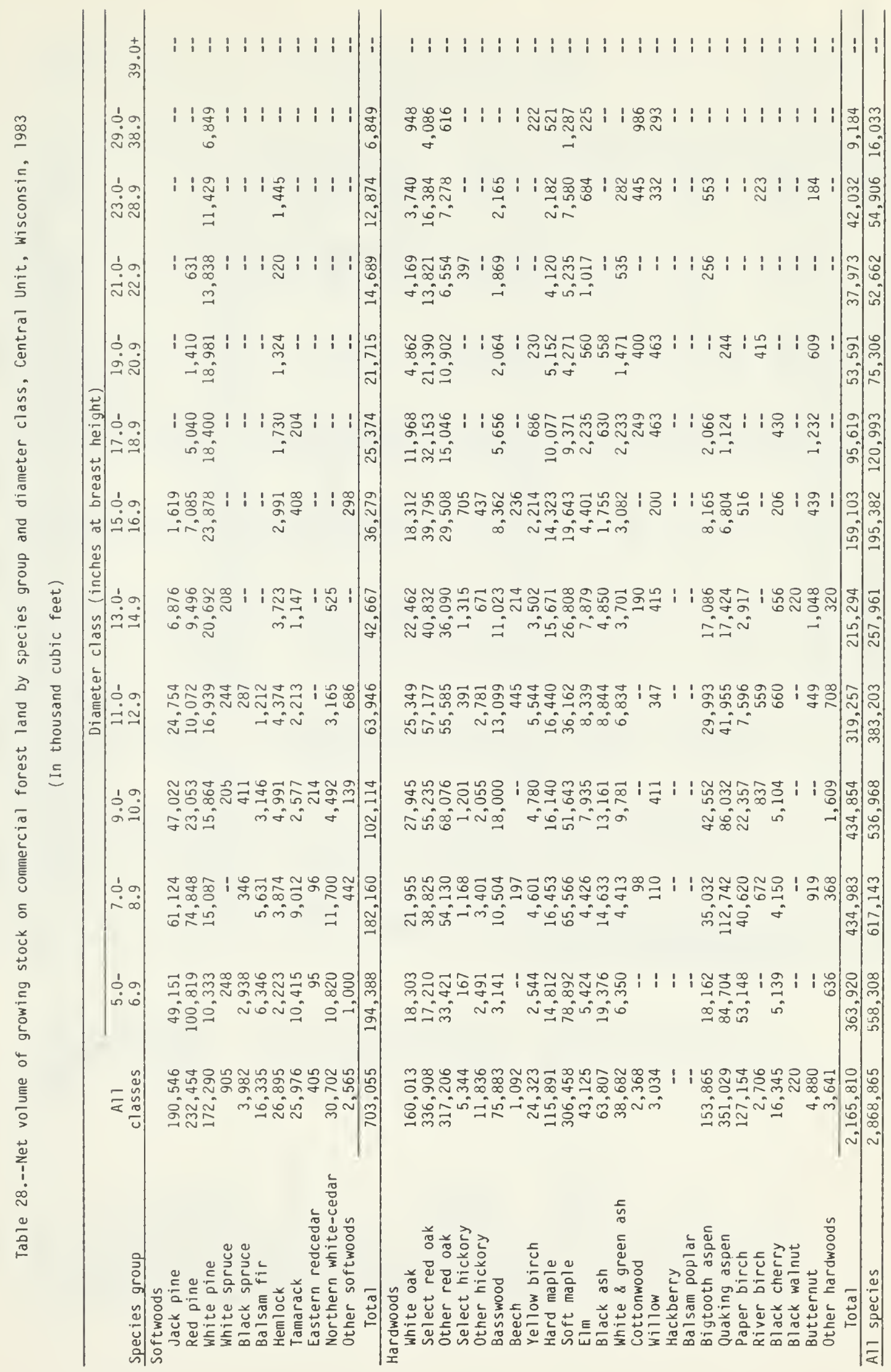




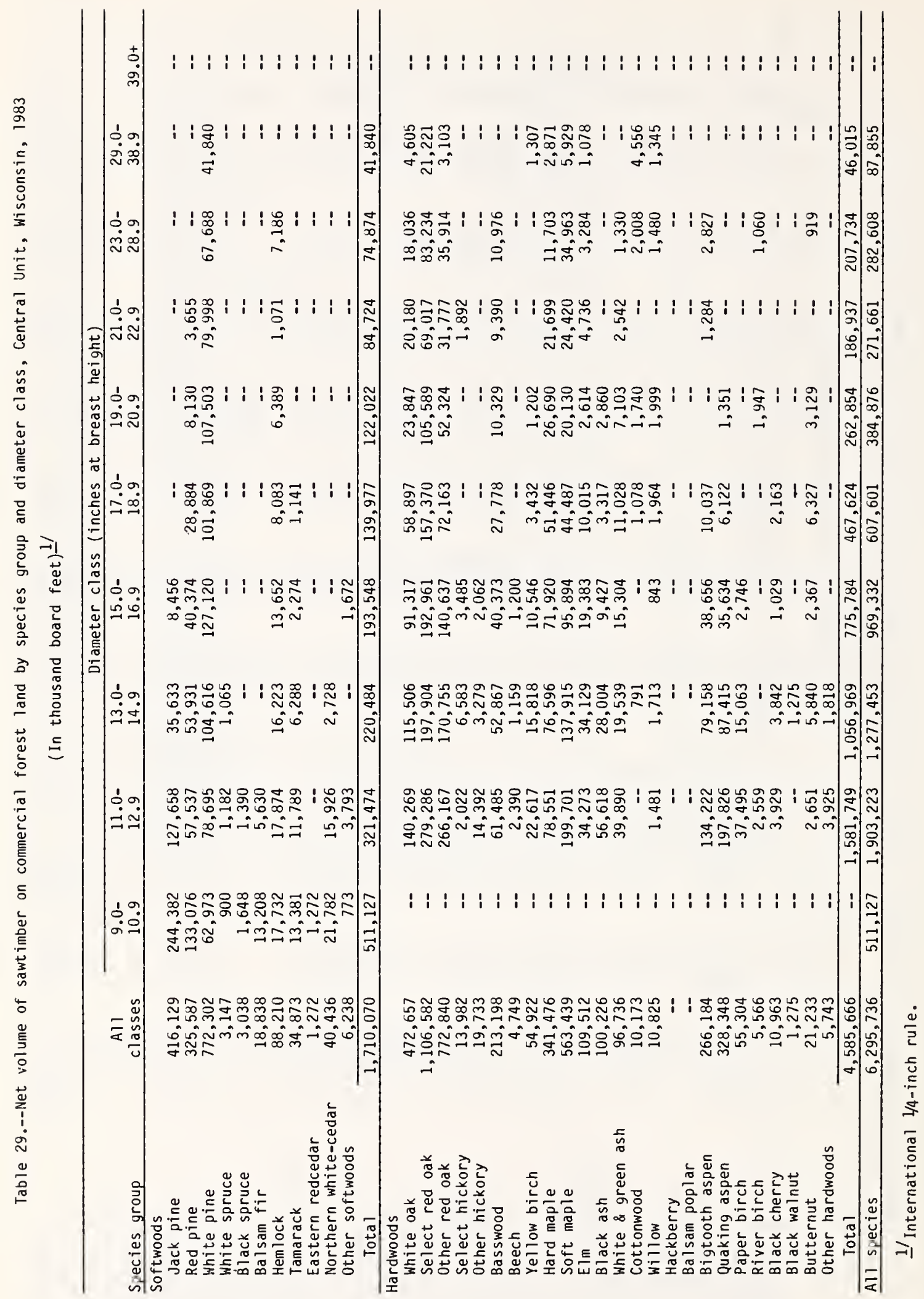


Table 30.--Net volume of growing stock on commercial forest land by species group and forest type, Central Unit, Wisconsin, 1983

(In thousand cubic feet)

\begin{tabular}{|c|c|c|c|c|c|c|c|c|}
\hline \multirow[b]{2}{*}{ Species group } & \multirow[b]{2}{*}{$\begin{array}{l}\text { All } \\
\text { types }\end{array}$} & \multicolumn{7}{|c|}{ Forest type } \\
\hline & & $\begin{array}{l}\text { Jack } \\
\text { pine }\end{array}$ & $\begin{array}{l}\text { Red } \\
\text { pine }\end{array}$ & $\begin{array}{l}\text { White } \\
\text { pine }\end{array}$ & $\begin{array}{l}\text { Bals am } \\
\text { fir }\end{array}$ & $\begin{array}{l}\text { White } \\
\text { spruce }\end{array}$ & $\begin{array}{l}81 \text { ack } \\
\text { spruce }\end{array}$ & $\begin{array}{c}\text { Northern } \\
\text { white- } \\
\text { cedar }\end{array}$ \\
\hline \multicolumn{9}{|l|}{ Softwoods } \\
\hline Jack pine & 190,546 & 113,248 & 5,705 & 5,149 & -- & -- & - & -- \\
\hline Red pine & 232,454 & 6,570 & 200,820 & 11,284 & 539 & $\ldots$ & -- & -- \\
\hline White pine & 172,290 & 2,819 & 6,436 & 74,502 & 1,822 & -- & $\cdots$ & 637 \\
\hline White spruce & 905 & -. & 96 & -. & $\ldots$ & 152 & -- & -. \\
\hline 81 ack spruce & 3,982 & -- & 346 & -- & $\cdots$ & -- & 1,145 & 424 \\
\hline 8alsam fir & 16,335 & -- & - & -- & 4,693 & -- & -- & 3,257 \\
\hline Hemlock & 26,895 & -- & -- & -- & -- & -- & -- & 1,193 \\
\hline Tamarack & 25,976 & -- & -- & 370 & -- & -- & 896 & 1,126 \\
\hline Eastern redcedar & 405 & 214 & - & -- & - & -- & -- & -- \\
\hline Northern white-cedar & 30,702 & -- & -- & -- & -- & -- & -- & 20,521 \\
\hline Other softwoods & 2,565 & -- & 1,722 & -- & -- & $\cdots$ & $\cdots$ & -. \\
\hline Total & 703,055 & 122,851 & 215,125 & 91,305 & 7,054 & 152 & 2,041 & 27,158 \\
\hline \multicolumn{9}{|l|}{ Hardwoods } \\
\hline White oak & 160,013 & 753 & 368 & 2,382 & -- & -- & -- & -- \\
\hline Select red oak & 336,908 & 2,058 & 775 & 781 & 171 & -- & -- & 163 \\
\hline Dther red oak & 317,206 & 8,999 & 3,206 & 6,446 & - & -- & - & 144 \\
\hline Select hickory & 5,344 & -. & -- & 334 & -- & $\ldots$ & -- & $\ldots$ \\
\hline Other hickory & 11,836 & -- & -. & -- & -- & -- & -- & -- \\
\hline 8asswood & 75,883 & -- & 209 & - & 167 & -- & - & 296 \\
\hline Beech & 1,092 & -. & 418 & -- & $\ldots$ & -. & $\ldots$ & - \\
\hline Yellow birch & 24,323 & -- & -- & 370 & -- & -- & -- & 338 \\
\hline Hard maple & 115,891 & -- & 796 & 1,514 & - & -- & - & -. \\
\hline Soft maple & 306,458 & -- & 212 & 3,692 & 149 & - & - & 778 \\
\hline Elm & 43,125 & -- & -. & -- & 187 & -- & -- & 310 \\
\hline 81 ack ash & 63,807 & -- & -. & 867 & 924 & -- & -- & 1,063 \\
\hline White \& green ash & 38,682 & -- & 416 & -- & -. & -- & -- & -. \\
\hline Cottonwood & 2,368 & 98 & -- & -- & -- & -- & - & -- \\
\hline Willow & 3,034 &.- & -- & -- & -- & -- & -. & -- \\
\hline Hackberry & -. & -- & $\ldots$ & $\ldots$ & $\ldots$ & $\ldots$ & -. & -- \\
\hline 8alsam poplar & -- & - & - & - & $\cdots$ & - & - & -- \\
\hline 8igtooth aspen & 153,865 & 908 & 212 & 2,358 & -- & -- & -- & -- \\
\hline Quaking aspen & 351,029 & 3,783 & 160 & 7,910 & -- & -- & -- & 981 \\
\hline Paper birch & 127,154 & 395 & -- & 1,235 & 479 & -- & -. & 1,449 \\
\hline River birch & 2,706 & -- & -- & -- & -- & -- & -- & -- \\
\hline 81 ack cherry & 16,345 & -- & -- & 948 & -- & -- & -. & -- \\
\hline 81 ack walnut & 220 & -- & $\cdots$ & -- & $\cdots$ & - & $\cdots$ & -- \\
\hline Butternut & 4,880 & -- & -- & -- & -- & -- & -- & -- \\
\hline Other hardwoods & 3,641 & $\ldots$ & 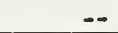 & -- & - & $\ldots$ & -- & -- \\
\hline Total & $2,165,810$ & 16,994 & 6,772 & 28,837 & 2,077 & -- & - & 5,522 \\
\hline All species & $2,868,865$ & 139,845 & 221,897 & 120,142 & 9,131 & 152 & 2,041 & 32,680 \\
\hline
\end{tabular}




\begin{tabular}{|c|c|c|c|c|c|c|c|c|}
\hline \multirow[b]{2}{*}{ Species group } & \multicolumn{8}{|c|}{ Forest type } \\
\hline & Tamarack & $\begin{array}{c}\text { 0ak- } \\
\text { hickory }\end{array}$ & $\begin{array}{l}\text { Elm-ash- } \\
\text { soft maple }\end{array}$ & $\begin{array}{l}\text { Maple- } \\
\text { birch }\end{array}$ & Aspen & $\begin{array}{l}\text { Paper } \\
\text { birch }\end{array}$ & Exotic & $\begin{array}{l}\text { Non- } \\
\text { stocked }\end{array}$ \\
\hline \multicolumn{9}{|l|}{ Softwoods } \\
\hline Jack pine & -- & 42,821 & 863 & 3,893 & 17,041 & 1,642 & -- & 184 \\
\hline Red pine & -- & 5,468 & 387 & 2,775 & 2,445 & 2,166 & -- & -- \\
\hline White pine & 869 & 28,469 & 11,684 & 34,456 & 5,994 & 4,602 & -- & $-\infty$ \\
\hline White spruce & -- & $=-$ & 208 & 449 & -- & $=-$ & -- & -- \\
\hline Black spruce & -- & -- & 411 & 287 & 1,369 & -- & -- & -- \\
\hline Bálsam fir & -- & 445 & 1,699 & 5,266 & 686 & 289 & -- & -- \\
\hline Hemlock & -- & 145 & 2,322 & 23,057 & 178 & -- & -- & -- \\
\hline Tamarack & 17,386 & -- & 4,696 & -- & 483 & 593 & -- & 426 \\
\hline Eastern redcedar & -- & 191 & - & -- & -- & -- & -- & -- \\
\hline Northern white-cedar & 270 & 238 & 4,242 & 4,135 & -- & 1,296 & -- & -- \\
\hline Other softwoods & -- & 287 & -- & -- & -- & -- & 556 & -- \\
\hline Tota 1 & 18,525 & 78,064 & 26,512 & 74,318 & 28,196 & 10,588 & 556 & 610 \\
\hline White oak & -- & 116,424 & 7,918 & 17,711 & 8,518 & 5,473 & $\rightarrow-$ & 466 \\
\hline Select red oak & -- & 242,013 & 8,773 & 52,333 & 23,865 & 5,821 & -- & 155 \\
\hline other red oak & -- & 258,680 & 5,530 & 10,724 & 21,112 & 976 & -- & 1,389 \\
\hline Select hickory & -- & 4,037 & 207 & -- & -- & 766 & -- & -- \\
\hline Other hickory & -- & 4,936 & -- & 6,103 & 797 & -- & -- & -- \\
\hline Basswood & -- & 7,850 & 10,153 & 52,988 & 3,306 & 426 & -- & 488 \\
\hline Beech & -- & -- & -- & 674 & -- & -- & -- & -- \\
\hline Yellow birch & 86 & 648 & 4,007 & 18,342 & -- & 532 & -- & -- \\
\hline Hard maple & -- & 10,464 & 1,025 & 96,882 & 3,108 & 2,102 & -- & $-\infty$ \\
\hline Soft maple & 584 & 50,084 & 88,671 & 102,929 & 53,386 & 5,973 & -- & -- \\
\hline Elm & 125 & 4,577 & 12,157 & 21,140 & 2,394 & 1,373 & -- & 862 \\
\hline Black ash & -- & 2,321 & 42,314 & 8,540 & 5,479 & 1,813 & -- & 486 \\
\hline White \& green ash & -- & 6,613 & 8,600 & 21,490 & 972 & 591 & -- & -- \\
\hline Cottonwood & -- & 1,159 & 393 & 253 & 232 & 233 & -- & $\infty$ \\
\hline Willow & -- & -- & 1,344 & 433 & 1,057 & 200 & -- & -- \\
\hline Hackberry & -- & -- & -- & -- & -- & -- & -- & - \\
\hline Balsam poplar & -- & -- & -- & -- & -- & - & -- & - \\
\hline Paper birch & 530 & 23,514 & 9,800 & 18,878 & 33,631 & 36,968 & -- & 275 \\
\hline River birch & -- & 525 & 2,181 & -- & -- & -- & -- & -- \\
\hline Black cherry & -- & 6,879 & 2,098 & 4,177 & 1,838 & 405 & -- & -- \\
\hline Black walnut & -- & -- & -- & 220 & -- & -- & -- & -- \\
\hline Butternut & -- & 2,129 & -- & 2,158 & 282 & 311 & -- & -- \\
\hline 0ther hardwoods & -- & 370 & 2,893 & 114 & 264 & -- & -- & - \\
\hline Tota 1 & 2,734 & 825,088 & 224,711 & 489,310 & 478,105 & 81,097 & -- & 4,563 \\
\hline All species & 21,259 & 903,152 & 251,223 & 563,628 & 506,301 & 91,685 & 556 & 5,173 \\
\hline
\end{tabular}


Table 31.--Net volume of sawtimber on commercial forest land by species group and forest type, Central Unit, Wisconsin, 1983

(In thousand board feet) 1 /

\begin{tabular}{|c|c|c|c|c|c|c|c|c|}
\hline \multirow[b]{2}{*}{ Species group } & \multirow[b]{2}{*}{$\begin{array}{c}\text { Al1 } \\
\text { types }\end{array}$} & \multicolumn{7}{|c|}{ Forest type } \\
\hline & & $\begin{array}{l}\text { Jack } \\
\text { pine }\end{array}$ & $\begin{array}{l}\text { Red } \\
\text { pine }\end{array}$ & $\begin{array}{l}\text { White } \\
\text { pine }\end{array}$ & $\begin{array}{c}\text { Balsam } \\
\text { fir }\end{array}$ & $\begin{array}{l}\text { White } \\
\text { spruce }\end{array}$ & $\begin{array}{l}\text { Black } \\
\text { spruce }\end{array}$ & $\begin{array}{c}\text { Northern } \\
\text { white- } \\
\text { cedar }\end{array}$ \\
\hline \multicolumn{9}{|l|}{ Softwoods } \\
\hline Jack pine & 416,129 & 216,356 & 10,606 & 11,650 & -- & -- & -- & -- \\
\hline Red pine & 325,587 & 20,778 & 201,784 & 43,508 & 3,124 & -- & -- & -- \\
\hline White pine & 772,302 & 11,742 & 11,584 & 332,967 & 9,527 & -- & - & 1,984 \\
\hline White spruce & 3,147 & -- & -- & -- & -- & -- & -- & $=$ \\
\hline Black spruce & 3,038 & -- & -- & -- & -- & $-\infty$ & $-\infty$ & -- \\
\hline Balsam fir & 18,838 & -- & -- & -- & 5,391 & -- & - & 2,774 \\
\hline Hemlock & 88,210 & - & -- & -- & -- & -- & -- & 3,506 \\
\hline Tamarack & 34,873 & -- & -- & 1,959 & -- & -- & $-\infty$ & 854 \\
\hline Eastern redcedar & 1,272 & 1,272 & -- & - & - & -- & - & - \\
\hline Northern white-cedar & 40,436 & $\ldots$ & -- & -- & -- & -- & -- & 24,515 \\
\hline Other softwoods & 6,238 & -- & 6,238 & -- & -- & -- & -- & -- \\
\hline Total & $1,710,070$ & 250,148 & 230,212 & 390,084 & 18,042 & -- & -- & 33,633 \\
\hline \multicolumn{9}{|l|}{ Hardwoods } \\
\hline White oak & 472,657 & $-\infty$ & 2,079 & 7,601 & -- & -- & -- & -- \\
\hline Select red oak & $1,106,582$ & 6,145 & 1,742 & 3,016 & 850 & -- & -- & 822 \\
\hline Other red oak & 772,840 & 19,446 & 9,386 & 16,898 & -- & -- & -- & 711 \\
\hline Select hickory & 13,982 & -- & - & - & - & -- & -- & - \\
\hline Other hickory & 19,733 & -- & -- & -- & $-\infty$ & -- & -- & -- \\
\hline Basswood & 213,198 & -- & 960 & $-\infty$ & 855 & -- & -- & 1,567 \\
\hline Beech & 4,749 & -- & 1,110 & -- & - & -- & -- & - \\
\hline Yellow birch & 54,922 & -- & -- & 1,307 & -- & -- & -- & -- \\
\hline Hard maple & 341,476 & -- & 895 & 7,033 & $-\infty$ & - & -- & -- \\
\hline Soft maple & 563,439 & - & 1,084 & 5,818 & $-\infty$ & -- & - & 1,816 \\
\hline Elm & 109,512 & -- & - & - & -- & -- & -- & 707 \\
\hline Black ash & 100,226 & -- & -- & 5,002 & 1,392 & -- & -- & 997 \\
\hline White \& green ash & 96,736 & -- & 2,188 & - & - & -- & -- & - \\
\hline Cottonwood & 10,173 & -- & -- & -- & $-\infty$ & -- & $-\infty$ & -- \\
\hline Willow & 10,825 & -- & -- & -- & -- & -- & -- & -- \\
\hline Hackberry & - & -- & -- & - & -- & -- & -- & - \\
\hline Balsam poplar & -- & -- & -- & -- & -- & - & -- & -- \\
\hline Bigtooth aspen & 266,184 & 800 & -- & 867 & -- & -- & -- & -- \\
\hline Quaking aspen & 328,348 & -- & -- & 2,159 & -- & -- & -- & 2,475 \\
\hline Paper birch & 55,304 & -- & -- & - & -- & -- & -- & 780 \\
\hline River birch & 5,566 & -- & -- & -- & -- & -- & - & - \\
\hline Black cherry & 10,963 & -- & -- & -- & $-\infty$ & -- & -- & $-\infty$ \\
\hline Black walnut & 1,275 & -- & -- & $-\infty$ & $-\infty$ & $-\infty$ & $-\infty$ & $-\infty$ \\
\hline Butternut & 21,233 & $-\infty$ & $-\infty$ & -- & -- & -- & -- & $-\infty$ \\
\hline Other hardwoods & 5,743 & $=$ & -- & -- & - & $=$ & -- & $-\infty$ \\
\hline Total & $4,585,666$ & 26,391 & 19,444 & 49,701 & 3,097 & $=$ & -- & 9,875 \\
\hline All species & $6,295,736$ & 276,539 & 249,656 & 439,785 & 21,139 & $=$ & -- & 43,508 \\
\hline
\end{tabular}


(Table 31 continued)

\begin{tabular}{|c|c|c|c|c|c|c|c|c|}
\hline \multirow[b]{2}{*}{ Species group } & \multicolumn{8}{|c|}{ Forest type } \\
\hline & Tamarack & $\begin{array}{c}\text { Oak- } \\
\text { hickory }\end{array}$ & $\begin{array}{l}\text { Elm-ash- } \\
\text { soft maple }\end{array}$ & $\begin{array}{l}\text { Maple- } \\
\text { birch }\end{array}$ & Aspen & $\begin{array}{l}\text { Paper } \\
\text { birch }\end{array}$ & Exotic & $\begin{array}{c}\text { Non- } \\
\text { stocked }\end{array}$ \\
\hline \multicolumn{9}{|l|}{ Softwoods } \\
\hline Jack pine & -- & 98,735 & 3,321 & 12,402 & 59,242 & 3,817 & - & -- \\
\hline Red pine & -- & 18,515 & 2,220 & 13,036 & 9,942 & 12,680 & -- & -- \\
\hline White pine & 3,921 & 129,376 & 52,574 & 171,672 & 29,836 & 17,119 & -- & - \\
\hline White spruce & - & 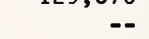 & 1,065 & 2,082 & -- & - & -- & -- \\
\hline Black spruce & -- & -- & 1,648 & 1,390 & -- & -- & -- & -- \\
\hline Balsam fir & -- & - & 2,910 & 6,885 & 878 & $=$ & -- & - \\
\hline Hemlock & -- & 494 & 5,560 & 77,924 & 726 & -- & -- & -- \\
\hline Tamarack & 13,383 & - & 12,705 & -- & 2,652 & 980 & - & 2,340 \\
\hline Eastern redcedar & -- & -- & -- & - & -- & - & -- & -. \\
\hline Northern white-cedar & -- & -- & 4,132 & 9,600 & -- & 2,189 & -- & -- \\
\hline other softwoods & -- & -- & - & - & -- & - & - & -- \\
\hline Total & 17,304 & 247,120 & 86,135 & 294,991 & 103,276 & 36,785 & -- & 2,340 \\
\hline \multicolumn{9}{|l|}{ Hardwoods } \\
\hline White oak & -- & 328,394 & 30,939 & 57,848 & 23,614 & 20,506 & -- & 1,676 \\
\hline Select red oak & -- & 789,672 & 35,438 & 187,451 & 56,506 & 24,129 & -- & 811 \\
\hline other red oak & -- & 601,836 & 23,955 & 37,681 & 56,351 & 4,462 & -- & 2,114 \\
\hline Select hickory & - & 10,426 & 985 & -- & 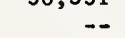 & 2,571 & -- & $2,-$ \\
\hline other hickory & -- & 6,678 & -- & 13,055 & -- & - & - & - \\
\hline Basswood & -- & 22,560 & 17,225 & 158,592 & 10,122 & 1,317 & -- & -- \\
\hline Beech & $\ldots$ & - & - & 3,639 & - & - & -- & -- \\
\hline Yellow birch & -- & 905 & 7,373 & 43,601 & - & 1,736 & $\ldots$ & - \\
\hline Hard maple & -- & 27,151 & 2,873 & 300,352 & 926 & 2,246 & -- & -- \\
\hline Soft maple & 766 & 76,557 & 223,795 & 212,469 & 31,284 & 9,850 & -- & - \\
\hline Elm & 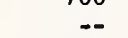 & 9,794 & 31,187 & 58,172 & 6,877 & 641 & -- & 2,134 \\
\hline Black ash & -- & 1,545 & 70,721 & 16,147 & 1,664 & 2,758 & -- & -. \\
\hline White \& green ash & -- & 8,978 & 34,949 & 49,088 & -- & 1,533 & -- & -- \\
\hline Cottonwood & -- & 5,080 & 1,810 & 1,132 & 1,086 & 1,065 & -- & -- \\
\hline Willow & - & - & 5,849 & 1,855 & 2,278 & 843 & -- & -- \\
\hline Hackberry & -- & -- & -- & -- & - & -- & $\ldots$ & - \\
\hline Balsam poplar & - & - & -- & -- & -- & -- & -- & -- \\
\hline Bigtooth aspen & 1,961 & 83,614 & -- & 36,150 & 128,807 & 13,985 & -- & -- \\
\hline Quaking aspen & - & 35,592 & 28,679 & 51,367 & 196,746 & 11,330 & -- & - \\
\hline Paper birch & -- & 9,032 & 6,600 & 17,412 & 4,111 & 17,369 & -- & -. \\
\hline River birch & -- & 1,010 & 4,556 & - & -- & -- & -- & -. \\
\hline Black cherry & - & 3,478 & -- & 6,420 & -- & 1,065 & -- & -- \\
\hline Black walnut & -- & -- & -- & 1,275 & -- & -. & -- & -- \\
\hline Butternut & $\ldots$ & 9,583 & $\ldots$ & 11,650 & - & - & - & -- \\
\hline other hardwoods & $=-$ & - & 5,743 & - & -- & -- & -- & -- \\
\hline Total & 2,727 & $2,031,885$ & 532,677 & $1,265,356$ & 520,372 & 117,406 & -- & 6,735 \\
\hline All species & 20,031 & $2,279,005$ & 618,812 & $1,560,347$ & 623,648 & 154,191 & -- & 9,075 \\
\hline
\end{tabular}




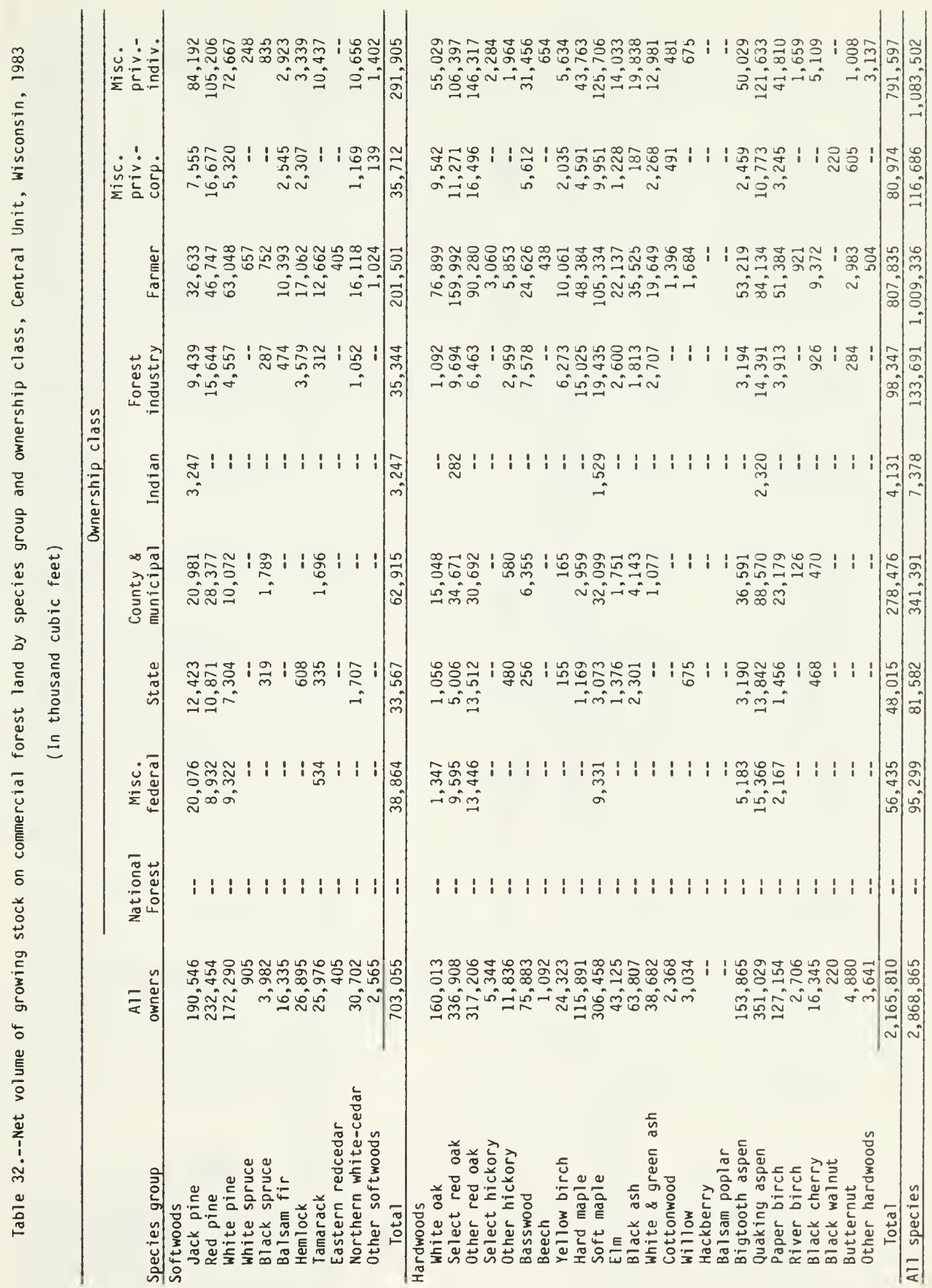




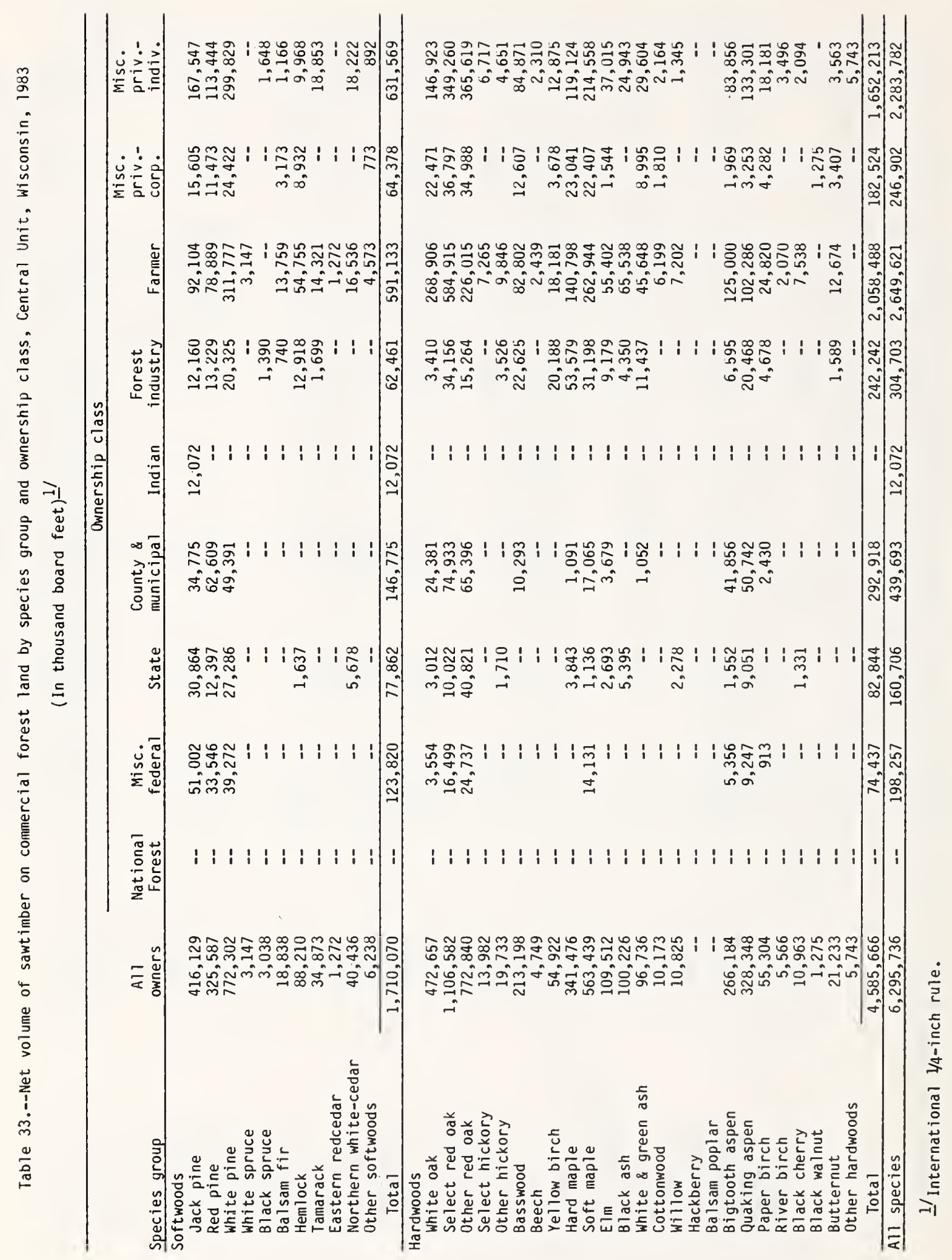



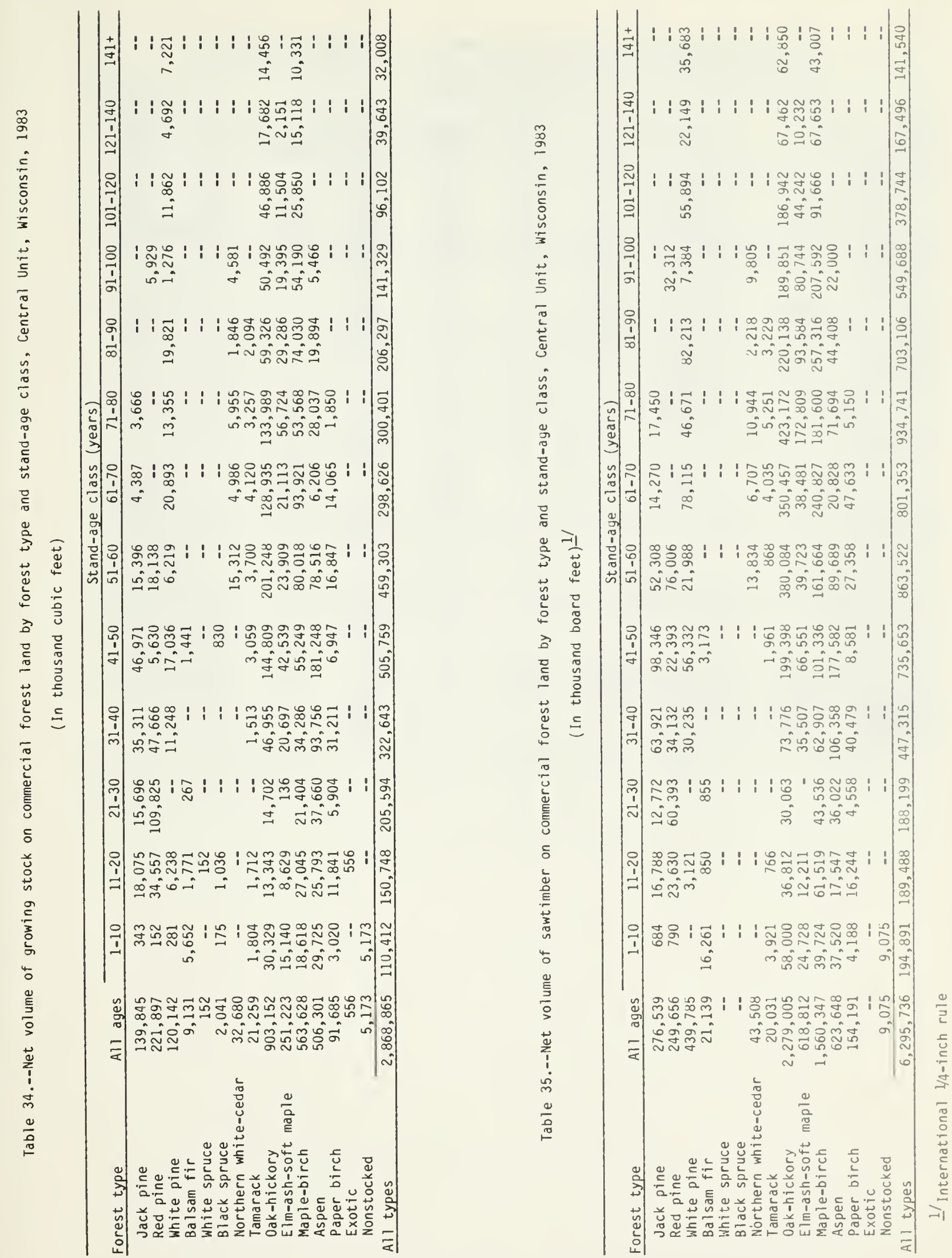
Table 36.--Net volume of growing stock on commercial forest land by forest type, stand-size class, and basal-area class, Central Unit, Wisconsin, 1983

(In thousand cubic feet)

\begin{tabular}{|c|c|c|c|c|c|c|c|c|}
\hline \multirow{2}{*}{$\begin{array}{l}\text { Forest type and } \\
\text { stand-size class }\end{array}$} & \multirow{2}{*}{$\begin{array}{c}\text { All } \\
\text { classes }\end{array}$} & \multicolumn{7}{|c|}{ Basal-area class (square feet per acre) } \\
\hline & & $0-10$ & $11-20$ & $21-30$ & $31-40$ & $41-50$ & $51-60$ & $61-70$ \\
\hline $\begin{array}{l}\text { Jack pine } \\
\text { Sawtimber } \\
\text { Poletimber } \\
\text { Sapling \& seedling }\end{array}$ & $\begin{array}{l}27,508 \\
89,310 \\
23,027 \\
\end{array}$ & $\begin{array}{l}-- \\
-- \\
-\end{array}$ & $\begin{array}{r}-- \\
-- \\
662 \\
\end{array}$ & $\begin{array}{r}-- \\
-- \\
873 \\
\end{array}$ & $\begin{array}{r}811 \\
2,059 \\
475 \\
\end{array}$ & $\begin{array}{r}-- \\
2,037 \\
1,202 \\
\end{array}$ & $\begin{array}{l}3,820 \\
6,154 \\
2,910 \\
\end{array}$ & $\begin{array}{l}1,559 \\
6,382 \\
4,714 \\
\end{array}$ \\
\hline All stands & 139,845 & -- & 662 & 873 & 3,345 & 3,239 & 12,884 & 12,655 \\
\hline $\begin{array}{l}\text { Red pine } \\
\text { Sawtimber } \\
\text { Poletimber } \\
\text { Sapling \& seedling }\end{array}$ & $\begin{array}{r}38,233 \\
177,318 \\
6,346 \\
\end{array}$ & $\begin{array}{r}-- \\
-- \\
152 \\
\end{array}$ & $\begin{array}{l}-- \\
-- \\
-\end{array}$ & $\begin{array}{l}-- \\
-- \\
--\end{array}$ & $\begin{array}{r}-- \\
-- \\
222 \\
\end{array}$ & $\begin{array}{l}-- \\
-- \\
--\end{array}$ & $\begin{array}{r}-- \\
1,769 \\
--\end{array}$ & $\begin{array}{r}-- \\
1,713 \\
--\end{array}$ \\
\hline All stands & 221,897 & 152 & -- & -- & 222 & -- & 1,769 & 1,713 \\
\hline $\begin{array}{l}\text { White pine } \\
\text { Sawtimber } \\
\text { Poletimber } \\
\text { Sapling \& seedling }\end{array}$ & $\begin{array}{r}103,194 \\
14,359 \\
2,589 \\
\end{array}$ & $\begin{array}{l}-- \\
-- \\
--\end{array}$ & $\begin{array}{r}647 \\
-- \\
-- \\
\end{array}$ & $\begin{array}{l}-- \\
-- \\
-\end{array}$ & $\begin{array}{l}-- \\
-- \\
-\end{array}$ & $\begin{array}{r}-- \\
-- \\
281 \\
\end{array}$ & $\begin{array}{r}1,276 \\
1,173 \\
918 \\
\end{array}$ & $\begin{array}{l}-- \\
-- \\
-\end{array}$ \\
\hline All stands & 120,142 & $\because$ & 647 & -- & -- & 281 & 3,367 & -- \\
\hline $\begin{array}{l}\text { Balsam fir } \\
\text { Sawtimber } \\
\text { Poletimber } \\
\text { Sapling \& seedling } \\
\text { All stands }\end{array}$ & $\begin{array}{r}1,441 \\
-- \\
7,690 \\
9,131\end{array}$ & $\begin{array}{l}-- \\
-- \\
-- \\
--\end{array}$ & $\begin{array}{l}-- \\
-- \\
-- \\
--\end{array}$ & $\begin{array}{r}-- \\
267 \\
267\end{array}$ & $\begin{array}{l}-- \\
-- \\
--\end{array}$ & $\begin{array}{r}1,441 \\
-- \\
2,154 \\
3,595\end{array}$ & $\begin{array}{l}-- \\
-- \\
--\end{array}$ & $\begin{array}{r}-- \\
1,771 \\
1,771\end{array}$ \\
\hline $\begin{array}{l}\text { White spruce } \\
\text { Sawtimber } \\
\text { Poletimber } \\
\text { Sapling \& seedling }\end{array}$ & $\begin{array}{r}-- \\
152 \\
\end{array}$ & $\begin{array}{l}-- \\
-- \\
--\end{array}$ & $\begin{array}{l}-- \\
-- \\
-\end{array}$ & $\begin{array}{l}-- \\
-- \\
--\end{array}$ & $\begin{array}{l}-- \\
-- \\
-\end{array}$ & $\begin{array}{l}-- \\
-- \\
--\end{array}$ & $\begin{array}{l}-- \\
-- \\
-\end{array}$ & $\begin{array}{l}-- \\
-- \\
-\end{array}$ \\
\hline Al1 stands & 152 & $\cdots$ & -- & -- & -- & $\cdots$ & -- & - \\
\hline $\begin{array}{l}\text { Black spruce } \\
\text { Sawtimber } \\
\text { Poletimber } \\
\text { Sapling \& seedling }\end{array}$ & $\begin{array}{r}-- \\
-\overline{-} \\
2,041 \\
\end{array}$ & $\begin{array}{r}-- \\
-- \\
175 \\
\end{array}$ & $\begin{array}{r}-- \\
319 \\
\end{array}$ & $\begin{array}{l}-- \\
-- \\
--\end{array}$ & $\begin{array}{l}-- \\
-- \\
-\end{array}$ & $\begin{array}{r}-- \\
183 \\
\end{array}$ & $\begin{array}{r}-- \\
534 \\
\end{array}$ & $\begin{array}{l}-- \\
-- \\
-\end{array}$ \\
\hline All stands & 2,041 & 175 & 319 & -- & -- & 183 & 534 & -- \\
\hline $\begin{array}{l}\text { Northern white-cedar } \\
\text { Sawtimber } \\
\text { Poletimber } \\
\text { Sapling \& seedling }\end{array}$ & $\begin{array}{r}2,042 \\
30,067 \\
571 \\
\end{array}$ & $\begin{array}{l}-- \\
-- \\
--\end{array}$ & $\begin{array}{l}-- \\
-- \\
-\end{array}$ & $\begin{array}{l}-- \\
-- \\
--\end{array}$ & $\begin{array}{l}-- \\
-- \\
--\end{array}$ & $\begin{array}{l}-- \\
-- \\
--\end{array}$ & $\begin{array}{l}-- \\
-- \\
--\end{array}$ & $\begin{array}{l}-- \\
-- \\
-\end{array}$ \\
\hline All stands & 32,680 & -- & -- & $-\cdot$ & -- & -- & -- & -- \\
\hline
\end{tabular}

(Table 36 continued on next page) 
(Table 36 continued)

\begin{tabular}{|c|c|c|c|c|c|c|c|}
\hline \multirow{2}{*}{$\begin{array}{l}\text { Forest type and } \\
\text { stand-size class }\end{array}$} & \multicolumn{7}{|c|}{ Basal-area class (square feet per acre) } \\
\hline & $71-80$ & $81-90$ & $91-100$ & $101-120$ & $121-150$ & $151-180$ & $181+$ \\
\hline \multirow{5}{*}{$\begin{array}{l}\text { Jack pine } \\
\text { Sawtimber } \\
\text { Poletimber } \\
\text { Sapling \& seedling } \\
\text { All stands } \\
\end{array}$} & & & & & & & \\
\hline & 2,045 & 4,365 & 3,247 & 7,958 & 3,703 & - & - \\
\hline & 13,618 & 26,397 & 12,210 & 12,510 & 2,685 & -- & 5,258 \\
\hline & 12,191 & -- & -- & -- & -- & -- & - \\
\hline & 27,854 & 30,762 & 15,457 & 20,468 & 6,388 & -- & 3,258 \\
\hline \multirow{5}{*}{$\begin{array}{l}\text { Red pine } \\
\text { Sawtimber } \\
\text { Polet imber } \\
\text { Sapling \& seedling } \\
\text { All stands }\end{array}$} & & & & & & & \\
\hline & 2,598 & 7,770 & 3,898 & 8,215 & 9,682 & 6,070 & \\
\hline & 4,874 & 5,370 & 3,802 & 27,530 & 34,050 & 21,632 & 76,578 \\
\hline & 2,472 & 1,531 & -- & 1,969 & -- & -- & - \\
\hline & 9,944 & 14,671 & 7,700 & 37,714 & 43,732 & 27,702 & 76,578 \\
\hline \multirow{5}{*}{$\begin{array}{l}\text { White pine } \\
\text { Sawtimber } \\
\text { Poletimber } \\
\text { Sapling \& seedling } \\
\text { All stands }\end{array}$} & & & & & & & \\
\hline & 8,319 & 9,167 & 6,915 & 37,569 & 33,220 & 6,081 & -- \\
\hline & -. & 1,628 & - & 2,620 & - & 8,938 & -- \\
\hline & 1,390 & $\ldots$ & -- & - & - & -- & - \\
\hline & 9,709 & 10,795 & 6,915 & 40,189 & 33,220 & 15,019 & -- \\
\hline \multicolumn{8}{|l|}{ Balsam fịr } \\
\hline Sawtimber & -- & -- & -- & -- & -- & -- & -- \\
\hline Poletimber & _- & -. & -- & -- & -- & -. & $\ldots$ \\
\hline Sapling \& seedling & 3,498 & -- & -- & -- & -- & -- & - \\
\hline All stands & 3,498 & -- & -- & -- & -- & -- & - \\
\hline \multicolumn{8}{|l|}{ White spruce } \\
\hline Sawt imber & -- & -- & -- & -- & -- & -- & -- \\
\hline Poletimber & -- & -- & -- & -- & -- & -- & - \\
\hline Sapling \& seedling & 152 & -- & -- & -- & -- & -- & - \\
\hline All stands & 152 & -- & -- & -- & -- & -- & -- \\
\hline \multicolumn{8}{|l|}{ Black spruce } \\
\hline Sawtimber & -- & -- & -- & -- & -- & -- & -- \\
\hline Poletimber & -- & -- & -- & -- & -- & -- & -- \\
\hline Sapling \& seedling & -- & -- & -- & 830 & -- & -- & -- \\
\hline All stands & -- & - & $=$ & 830 & - & - & -- \\
\hline \multicolumn{8}{|l|}{ Northern white-cedar } \\
\hline Sawtimber & 2,042 & -- & -- & -- & -- & -. & -- \\
\hline Poletimber & -- & -- & -- & 1,846 & 3,032 & 5,955 & 19,234 \\
\hline Sapling \& seedling & $\cdots$ & - & - & 571 & - & - & - \\
\hline All stands & 2,042 & -- & -- & 2,417 & 3,032 & 5,955 & 19,234 \\
\hline
\end{tabular}


(Table 36 continued)

\begin{tabular}{|c|c|c|c|c|c|c|c|c|}
\hline \multirow{2}{*}{$\begin{array}{l}\text { Forest type and } \\
\text { stand-size class }\end{array}$} & \multirow{2}{*}{$\begin{array}{c}\text { All } \\
\text { classes }\end{array}$} & \multicolumn{7}{|c|}{ Basal-area class (square feet per acre) } \\
\hline & & $0-10$ & $11-20$ & $21-30$ & $31-40$ & $41-50$ & $51-60$ & $61-70$ \\
\hline \multicolumn{9}{|l|}{ Tamarack } \\
\hline Sawt imber & 970 & -- & -- & 970 & -- & -- & -- & -- \\
\hline Poletimber & 16,773 & -- & -- & -- & 1,199 & 1,513 & -- & -- \\
\hline Sapling \& seedling & 3,516 & 115 & 259 & -- & - & 2,025 & -- & 1,117 \\
\hline All stands & 21,259 & 115 & 259 & 970 & 1,199 & 3,538 & $\ldots$ & 1,117 \\
\hline \multicolumn{9}{|l|}{ 0ak-hickory } \\
\hline Sawt imber & 463,999 & -- & -- & 1,203 & 840 & 13,017 & 19,397 & 21,720 \\
\hline Poletimber & 391,293 & -- & -- & & 2,793 & 1,076 & 30,349 & 13,682 \\
\hline Sapling \& seedling & 47,860 & 180 & 1,116 & 8,392 & 3,317 & 10,829 & 10,825 & 7,849 \\
\hline All stands & 903,152 & 180 & 1,116 & 9,595 & 6,950 & 24,922 & 60,571 & 43,251 \\
\hline \multicolumn{9}{|l|}{ Elm-ash-soft maple } \\
\hline Sawt imber & 133,046 & - & 450 & 1,107 & -- & 3,873 & 1,905 & 4,393 \\
\hline Poletimber & 94,272 & -- & 2,759 & 758 & 4,326 & 4,246 & 9,362 & 6,641 \\
\hline Sapling \& seedling & 23,905 & 247 & 1,411 & 1,077 & 3,793 & 2,356 & 7,636 & 2,099 \\
\hline All stands & 251,223 & 247 & 4,620 & 2,942 & 8,119 & 10,475 & 18,903 & 13,133 \\
\hline \multicolumn{9}{|l|}{ Maple-birch } \\
\hline Sawt imber & 334,782 & -- & -- & 2,058 & -- & 8,144 & 9,250 & 2,729 \\
\hline Polet imber & 168,266 & -- & -- & 2,034 & 2,272 & 2,754 & 8,166 & 9,210 \\
\hline Sapling \& seedling & 60,580 & 378 & 2,033 & 4,612 & 4,450 & 6,910 & 6,452 & 4,764 \\
\hline All stands & 563,628 & 378 & 2,033 & 8,704 & 6,722 & 17,808 & 23,868 & 16,703 \\
\hline \multicolumn{9}{|l|}{ Aspen } \\
\hline Sawt imber & 97,348 & -- & 627 & -- & 571 & 3,302 & 2,395 & 2,177 \\
\hline Polet imber & 335,599 & -- & 438 & 873 & 2,281 & 8,743 & 20,115 & 27,083 \\
\hline Sapling \& seedling & 73,354 & 500 & 5,949 & 4,165 & 9,877 & 20,442 & 8,414 & 12,204 \\
\hline All stands & 506,301 & 500 & 7,014 & 5,038 & 12,729 & 32,487 & 30,924 & 41,464 \\
\hline \multicolumn{9}{|l|}{ Paper birch } \\
\hline Sawtimber & 15,915 & -- & -- & -- & -- & -- & $\ldots$ & 6,299 \\
\hline Poletimber & 57,134 & -- & -- & -- & -- & 2,300 & 2,874 & 1,078 \\
\hline Sapling \& seedling & 18,636 & - & 1,403 & 1,711 & 3,153 & 2,925 & 4,096 & - \\
\hline All stands & 91,685 & -- & 1,403 & 1,711 & 3,153 & 5,225 & 6,970 & 7,377 \\
\hline \multicolumn{9}{|l|}{ Exotic } \\
\hline Sawtimber & -- & -- & -- & -- & -- & -- & -- & -- \\
\hline Poletimber & -- & -- & -- & -_ & -- & -- & -- & -. \\
\hline Sapling \& seedling & 556 & -- & -- & -- & - & -- & -- & -- \\
\hline A11 stands & 556 & - & -- & -- & - & -- & -- & - \\
\hline Nonstocked & 5,173 & 426 & 1,332 & -- & 395 & -- & $\ldots$ & - \\
\hline \multicolumn{9}{|l|}{ A11 types } \\
\hline Sawtimber & $1,218,478$ & -- & 1,724 & 5,338 & 2,222 & 29,777 & 38,043 & 38,877 \\
\hline Polet imber & $1,374,391$ & $\ldots$ & 3,197 & 3,665 & 14,930 & 22,669 & 79,962 & 65,789 \\
\hline Sapling \& seedling & 270,823 & 1,747 & 13,152 & 21,097 & 25,287 & 49,307 & 41,785 & 34,518 \\
\hline Nonstocked & 5,173 & 426 & 1,332 & - & 395 & - & -- & -- \\
\hline All stands & $2,868,865$ & 2,173 & 19,405 & 30,100 & 42,834 & 101,753 & 159,790 & 139,184 \\
\hline
\end{tabular}


(Table 36 continued)

\begin{tabular}{|c|c|c|c|c|c|c|c|}
\hline \multirow{2}{*}{$\begin{array}{l}\text { Forest type and } \\
\text { stand-size class }\end{array}$} & \multicolumn{7}{|c|}{ Basal-area class (square feet per acre) } \\
\hline & $71-80$ & $81-90$ & $91-100$ & $101-120$ & $121-150$ & $151-180$ & $181+$ \\
\hline \multicolumn{8}{|l|}{ Tamarack } \\
\hline Sawtimber & -- & -- & -- & -- & - & -- & -- \\
\hline Poletimber & -- & 7,440 & 6,621 & -- & -- & -. & -- \\
\hline Sapling \& seedling & -- & -. & - & -- & -- & -- & -- \\
\hline All stands & -- & 7,440 & 6,621 & -- & -- & -- & -- \\
\hline \multicolumn{8}{|l|}{ Oak-hickory } \\
\hline Sawtimber & 31,080 & 48,753 & 32,091 & 133,240 & 133,002 & 19,540 & 10,116 \\
\hline Poletimber & 40,682 & 61,545 & 42,304 & 60,787 & 106,094 & 29,815 & 2,166 \\
\hline Sapling \& seedling & 3,186 & 1,388 & 778 & -- & - & $\ldots$ & -- \\
\hline All stands & 74,948 & 111,686 & 75,173 & 194,027 & 239,096 & 49,355 & 12,282 \\
\hline \multicolumn{8}{|l|}{ Elm-ash-soft maple } \\
\hline Sawt imber & 10,324 & 10,319 & 24,685 & 18,205 & 38,608 & 19,177 & $=-$ \\
\hline Poletimber & 9,657 & 13,166 & 1,615 & 17,451 & 7,368 & 10,072 & 6,851 \\
\hline Sapling \& seedling & 3,141 & -- & - & 2,145 & - & - & - \\
\hline All stands & 23,122 & 23,485 & 26,300 & 37,801 & 45,976 & 29,249 & 6,851 \\
\hline \multicolumn{8}{|l|}{ Maple-birch } \\
\hline Sawt imber & 24,631 & 48,660 & 23,445 & 57,713 & 101,193 & 42,323 & 14,636 \\
\hline Poletimber & 13,583 & 9,541 & 22,269 & 32,673 & 50,038 & 5,366 & 10,360 \\
\hline Sapling \& seedling & 8,281 & 8,266 & 3,005 & 8,663 & 2,766 & -. & -. \\
\hline All stands & 46,495 & 66,467 & 48,719 & 99,049 & 153,997 & 47,689 & 24,996 \\
\hline \multicolumn{8}{|l|}{ Aspen } \\
\hline Sawtimber & 7,971 & 9,786 & 9,868 & 33,210 & 11,080 & 16,361 & -- \\
\hline Poletimber & 32,820 & 49,098 & 18,476 & 92,799 & 53,745 & 22,090 & 7,038 \\
\hline Sapling \& seedling & 3,935 & 5,367 & -- & 2,501 & $\ldots$ & -- & - \\
\hline Al 1 stands & 44,726 & 64,251 & 28,344 & 128,510 & 64,825 & 38,451 & 7,038 \\
\hline \multicolumn{8}{|l|}{ Paper birch } \\
\hline Sawt imber & 1,850 & 4,197 & -- & -- & 3,569 & & -- \\
\hline Poletimber & 12,868 & 4,783 & 3,817 & 2,378 & 21,477 & 5,559 & -- \\
\hline Sapling \& seedling & -- & 3,294 & -- & 2,054 & -- & -- & -- \\
\hline All stands & 14,718 & 12,274 & 3,817 & 4,432 & 25,046 & 5,559 & $=$ \\
\hline \multicolumn{8}{|l|}{ Exotic } \\
\hline Sawtimber & -- & -- & -- & -- & $\ldots$ & -- & -. \\
\hline Poletimber & -- & -- & -- & -- & -- & -- & -- \\
\hline Sapling \& seedling & 556 & -- & -- & -- & -- & -- & - \\
\hline All stands & 556 & -- & $=$ & $=$ & -- & -- & -- \\
\hline Nonst ocked & -- & -- & 2,106 & -- & 914 & -- & - \\
\hline \multicolumn{8}{|l|}{ All types } \\
\hline Sawt imber & 90,860 & 143,017 & 104,149 & 296,110 & 334,057 & 109,552 & 24,752 \\
\hline Poletimber & 128,102 & 178,968 & 111,114 & 250,594 & 278,489 & 109,427 & 127,485 \\
\hline Sapling \& seedling & 38,802 & 19,846 & 3,783 & 18,733 & 2,766 & -- & - \\
\hline Nonstocked & -- & -- & 2,106 & -- & 914 & -- & -- \\
\hline All stands & 257,764 & 341,831 & 221,152 & 565,437 & 616,226 & 218,979 & 152,237 \\
\hline
\end{tabular}


Table 37.--Net volume of sawtimber on commercial forest land by forest type, stand-size class, and basal-area class, Central Unit, Wisconsin, 1983

(In thousand board feet) 1 -

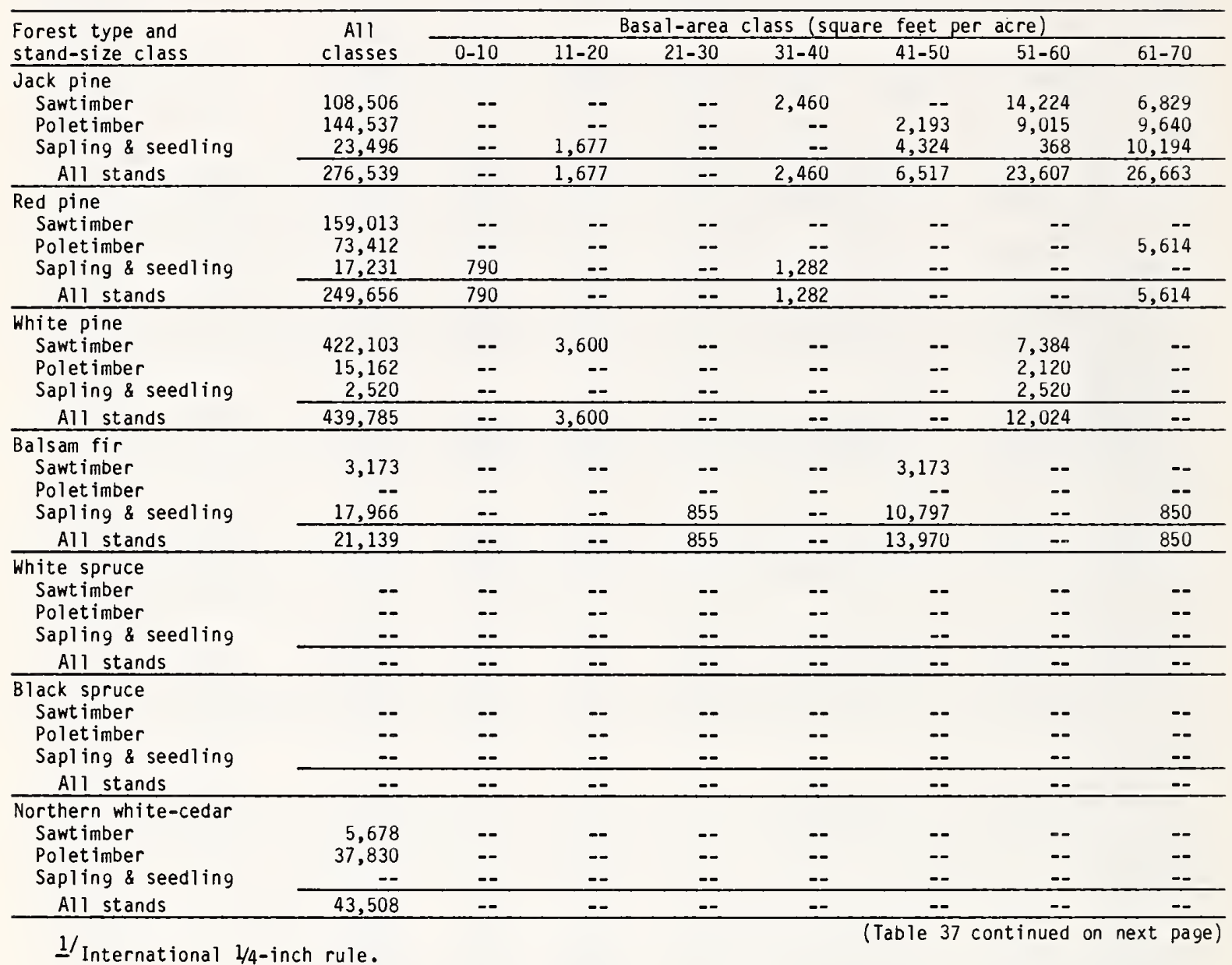


(Table 37 continued)

\begin{tabular}{|c|c|c|c|c|c|c|c|}
\hline \multirow{2}{*}{$\begin{array}{l}\text { Forest type and } \\
\text { stand-size class }\end{array}$} & \multicolumn{7}{|c|}{ Basal-area class (square feet per acre) } \\
\hline & $71-80$ & $81-90$ & $91-100$ & $101-120$ & $121-150$ & $151-180$ & $181+$ \\
\hline \multicolumn{8}{|l|}{ Jack pine } \\
\hline Sawt imber & 9,029 & 14,407 & 12,072 & 31,410 & 18,075 & -- & $2=-$ \\
\hline $\begin{array}{l}\text { Poletimber } \\
\text { Sapling \& seedling }\end{array}$ & $\begin{array}{r}23,678 \\
6,933\end{array}$ & & $\begin{array}{r}21,095 \\
-.\end{array}$ & $\begin{array}{r}21,581 \\
--\end{array}$ & $\begin{array}{r}4,749 \\
--\end{array}$ & $\begin{array}{l}-- \\
--\end{array}$ & $\begin{array}{r}4,235 \\
--\end{array}$ \\
\hline All stands & 39,640 & 56,752 & 33,167 & 58,997 & 22,824 & -- & 4,235 \\
\hline \multicolumn{8}{|l|}{ Red pine } \\
\hline Sawt imber & 10,897 & 32,416 & 10,387 & 38,079 & 44,944 & 22,290 & \\
\hline Poletimber & & & -- & 7,411 & 16,371 & 3,754 & 40,262 \\
\hline Sápling \& seedling & 4,017 & 4,016 & -- & 7,126 & -- & -- & -- \\
\hline All stands & 14,914 & 36,432 & 10,387 & 52,616 & 61,315 & 26,044 & 40,262 \\
\hline \multicolumn{8}{|l|}{ White pine } \\
\hline Sawt imber & 40,761 & 37,068 & 24,797 & 166,133 & 122,862 & 19,498 & -- \\
\hline Poletimber & -- & 1,772 & -- & 1,814 & -- & 9,456 & -- \\
\hline Sapling \& seedling & -- & -- & -- & -- & $=$ & - & - \\
\hline All stands & 40,761 & 38,840 & 24,797 & 167,947 & 122,862 & 28,954 & $\cdots$ \\
\hline \multicolumn{8}{|l|}{ Balsam fir } \\
\hline Sawt imber & -- & -- & - & - & - & -- & -- \\
\hline Poletimber & -- & -- & -- & -- & -- & -- & -- \\
\hline Sapling \& seedling & 5,464 & -- & -- & -- & $\cdots$ & -- & -- \\
\hline All stands & 5,464 & -- & -- & -- & -- & -- & - \\
\hline \multicolumn{8}{|l|}{ White spruce } \\
\hline Sawt imber & -- & -- & -- & -- & -- & -- & -- \\
\hline Poletimber & -- & -- & -- & -- & -- & -- & -- \\
\hline Sapling \& seedling & - & -- & -- & -- & -- & $\cdots$ & - \\
\hline All stands & -- & -- & -- & -- & -- & -- & -- \\
\hline \multicolumn{8}{|l|}{ Black spruce } \\
\hline Sawt imber & -- & -- & -- & -- & -- & -- & -- \\
\hline Polet imber & -- & -- & - & -- & -- & -- & -- \\
\hline Sapling \& seedling & $=$ & -- & -- & -- & -- & -- & $=$ \\
\hline All stands & -- & -- & -- & -- & $=$ & -- & - \\
\hline \multicolumn{8}{|l|}{ Northern white-cedar } \\
\hline Sawt imber & 5,678 & -- & -- & -- & $\cdots$ & -- & -- \\
\hline Polet imber & -- & -- & -- & 2,218 & 2,310 & 10,944 & 22,358 \\
\hline Sapling \& seedling & -- & -- & -- & - & -- & - & - \\
\hline All stands & 5,678 & -- & - & 2,218 & 2,310 & 10,944 & 22,358 \\
\hline
\end{tabular}


(Table 37 continued)

\begin{tabular}{|c|c|c|c|c|c|c|c|c|}
\hline \multirow{2}{*}{$\begin{array}{l}\text { Forest type and } \\
\text { stand-size class }\end{array}$} & \multirow{2}{*}{$\begin{array}{c}\text { All } \\
\text { classes }\end{array}$} & \multicolumn{7}{|c|}{ Basal-area class (square feet per acre) } \\
\hline & & $0-10$ & $11-20$ & $21-30$ & $31-40$ & $41-50$ & $51-60$ & $61-70$ \\
\hline \multicolumn{9}{|l|}{ Tamarack } \\
\hline Sawtimber & 4,318 & -- & -- & 4,318 & -- & -- & -- & -- \\
\hline Poletimber & 11,026 & -- & -- & -- & -- & -- & -- & -- \\
\hline Sapling \& seedling & 4,687 & 766 & -- & -- & -- & 3,921 & -- & -- \\
\hline A11 stands & 20,031 & 766 & -- & 4,318 & -- & 3,921 & -- & - \\
\hline \multicolumn{9}{|l|}{ 0ak-hickory } \\
\hline Sawtimber & $1,624,490$ & -- & -- & 6,265 & 3,016 & 49,526 & 75,274 & 75,328 \\
\hline Poletimber & 547,769 & -- & -- & & 4,423 & 1,321 & 46,669 & 24,440 \\
\hline Sapling \& seedling & 106,746 & -- & 2,437 & 19,362 & 10,643 & 16,555 & 20,601 & 25,350 \\
\hline A11 stands & $2,279,005$ & -- & 2,437 & 25,627 & 18,082 & 67,402 & 142,544 & 125,118 \\
\hline \multicolumn{9}{|l|}{ Elm-ash-soft maple } \\
\hline Sawtimber & 455,605 & -- & 1,422 & 5,868 & & 19,261 & 6,022 & 20,483 \\
\hline Poletimber & 126,268 & -- & & 1,657 & 7,498 & 1,700 & 14,630 & 10,551 \\
\hline Sapling \& seedling & 36,939 & 547 & 1,686 & 3,220 & 3,766 & 1,604 & 12,094 & 2,751 \\
\hline All stands & 618,812 & 547 & 3,108 & 10,745 & 11,264 & 22,565 & 32,746 & 33,785 \\
\hline \multicolumn{9}{|l|}{ Maple-birch } \\
\hline Sawtimber & $1,156,430$ & -- & -- & 7,778 & -- & 27,924 & 29,011 & 9,913 \\
\hline Poletimber & 271,922 & -- & -- & 2,183 & 4,731 & 2,081 & 15,137 & 19,077 \\
\hline Sapling \& seedling & 131,995 & 1,381 & 2,178 & 7,479 & 11,777 & 19,661 & 10,154 & 4,433 \\
\hline All stands & $1,560,347$ & 1,381 & 2,178 & 17,440 & 16,508 & 49,666 & 54,302 & 33,423 \\
\hline \multicolumn{9}{|l|}{ Aspen } \\
\hline Sawtimber & 267,209 & -- & 2,559 & -- & 1,997 & 11,236 & 9,320 & 9,471 \\
\hline Poletimber & 286,712 & -- & & 695 & 1,397 & 8,863 & 22,333 & 27,997 \\
\hline Sapling \& seedling & 69,727 & 1,091 & 16,970 & 878 & 5,729 & 15,775 & 9,403 & 11,904 \\
\hline A11 stands & 623,648 & 1,091 & 19,529 & 1,573 & 9,123 & 35,874 & 41,056 & 49,372 \\
\hline \multicolumn{9}{|l|}{ Paper birch } \\
\hline Sawtimber & 52,783 & -- & -- & -- & -- & -- & -- & 23,043 \\
\hline Poletimber & 77,483 & -- & -- & -- & -- & 1,908 & 1,474 & -- \\
\hline Sapling \& seedling & 23,925 & -- & 2,597 & 851 & 1,705 & 5,530 & 6,979 & -- \\
\hline All st ands & 154,191 & -- & 2,597 & 851 & 1,705 & 7,438 & 8,453 & 23,043 \\
\hline \multicolumn{9}{|l|}{ Exotic } \\
\hline Sawt imber & -- & -- & -- & -- & -- & -- & -- & -- \\
\hline Poletimber & - & -- & -- & -- & -- & -- & -- & -- \\
\hline Sapling \& seedling & -- & -- & -- & -- & -- & $\because$ & - & - \\
\hline All stands & -- & -- & -- & -- & -- & -- & -- & -- \\
\hline Nonstocked & 9,075 & 2,340 & 2,191 & -- & 1,863 & -- & -- & -- \\
\hline \multicolumn{9}{|l|}{ A11 types } \\
\hline Sawtimber & $4,259,308$ & -- & 7,581 & 24,229 & 7,473 & 111,120 & 141,235 & 145,067 \\
\hline Poletimber & $1,592,121$ & & & 4,535 & 18,049 & 18,066 & 111,378 & 97,319 \\
\hline Sapling \& seedling & 435,232 & 4,575 & 27,545 & 32,645 & 34,902 & 78,167 & 62,119 & 55,482 \\
\hline Nonstocked & 9,075 & 2,340 & 2,191 & -- & 1,863 & -- & -- & - \\
\hline All stands & $6,295,736$ & 6,915 & 37,317 & 61,409 & 62,287 & 207,353 & 314,732 & 297,868 \\
\hline
\end{tabular}


(Table 37 continued)

\begin{tabular}{|c|c|c|c|c|c|c|c|}
\hline \multirow{2}{*}{$\begin{array}{l}\text { Forest type and } \\
\text { stand-size class }\end{array}$} & \multicolumn{7}{|c|}{ Basal-area class (square feet per acre) } \\
\hline & $71-80$ & $81-90$ & $91-100$ & $101-120$ & $121-150$ & $151-180$ & $181+$ \\
\hline \multicolumn{8}{|l|}{ Tamarack } \\
\hline Sawtimber & -. & -- & -- & -- & -. & - & -- \\
\hline Poletimber & -- & 6,123 & 4,903 & -- & -. & -- & -. \\
\hline Sapling \& seedling & -- & -- & -- & -- & -- & -- & - \\
\hline All stands & $\cdots$ & 6,123 & 4,903 & -- & -- & -- & - \\
\hline \multicolumn{8}{|l|}{ 0ak-hickory } \\
\hline Sawt imber & 105,029 & 173,870 & 117,689 & 476,115 & 452,297 & 62,415 & 27,666 \\
\hline Poletimber & 41,926 & 87,218 & 64,067 & 92,750 & 153,371 & 30,489 & 1,095 \\
\hline Sapling \& seedling & 2,231 & 5,491 & 4,076 & -. & -- & -- & -. \\
\hline All stands & 149,186 & 266,579 & 185,832 & 568,865 & 605,668 & 92,904 & 28,761 \\
\hline \multicolumn{8}{|l|}{ Elm-ash-s oft maple } \\
\hline Sawt iınber & 42,306 & 34,147 & 80,242 & 53,500 & 139,974 & 52,380 & -- \\
\hline Poletimber & 15,926 & 19,024 & 845 & 26,024 & 13,357 & 4,789 & 10,267 \\
\hline Sapling \& seedling & 2,283 & - & - & 8,988 & - & - & -- \\
\hline All stands & 60,515 & 53,171 & 81,087 & 88,512 & 153,331 & 57,169 & 10,267 \\
\hline \multicolumn{8}{|l|}{ Maple-birch } \\
\hline Sawt imber & 88,852 & 186,657 & 76,894 & 193,944 & 346,741 & 138,999 & 49,717 \\
\hline Poletimber & 26,442 & 24,388 & 27,319 & 46,111 & 84,753 & 3,608 & 16,092 \\
\hline Sapling \& seedling & 7,024 & 26,768 & 6,699 & 27,933 & 6,508 & - & -- \\
\hline All stands & 122,318 & 237,813 & 110,912 & 267,988 & 438,002 & 142,607 & 65,809 \\
\hline \multicolumn{8}{|l|}{ Aspen } \\
\hline Sawt imber & 23,632 & 28,826 & 23,025 & 96,314 & 27,268 & 33,561 & -- \\
\hline Polet imber & 27,652 & 58,117 & 12,942 & 62,442 & 48,773 & 10,653 & 4,848 \\
\hline Sapling \& seedling & -. & 6,731 & - & 1,246 & -. & -. & -. \\
\hline All stands & 51,284 & 93,674 & 35,967 & 160,002 & 76,041 & 44,214 & 4,848 \\
\hline \multicolumn{8}{|l|}{ Paper birch } \\
\hline Sawt imber & 5,150 & 11,190 & -- & -- & 13,400 & -- & -- \\
\hline Polet imber & 16,530 & 11,484 & 1,172 & 3,912 & 34,930 & 6,073 & -- \\
\hline Sapling \& seedling & -- & 6,263 & - & - & -- & -- & -- \\
\hline All stands & 21,680 & 28,937 & 1,172 & 3,912 & 48,330 & 6,073 & -- \\
\hline \multicolumn{8}{|l|}{ Exotic } \\
\hline Sawt imber & -- & -- & -- & -- & -- & -- & -- \\
\hline Poletimber & -- & -- & -- & -- & -- & -- & -- \\
\hline Sapling \& seedling & -- & -- & -- & -- & -- & -- & -- \\
\hline All stands & -- & -- & $\cdots$ & -- & -- & $\cdots$ & $\cdots$ \\
\hline Nonstocked & $\because-$ & -- & 2,681 & -- & -- & -- & -- \\
\hline \multicolumn{8}{|l|}{ All types } \\
\hline Sawt imber & 331,334 & 518,581 & 345,106 & $1,055,495$ & $1,165,561$ & 329,143 & 77,383 \\
\hline Poletimber & 152,154 & 250,471 & 132,343 & 270,269 & 358,614 & 79,766 & 99,157 \\
\hline Sapling \& seedling & 27,952 & 49,269 & 10,775 & 45,293 & 6,508 & -. & -- \\
\hline Nonstocked & -- & - & 2,681 & -- & -- & -- & - \\
\hline All stands & 511,440 & 818,321 & 490,905 & $1,371,057$ & $1,530,683$ & 408,909 & 176,540 \\
\hline
\end{tabular}


Table 38.--Net volume of sawtimber on commercial forest land by species group and butt log grade, Central Unit, Wisconsin, 1983

(In thousand board feet) $\underline{1}$ '

\begin{tabular}{|c|c|c|c|c|c|}
\hline \multirow[b]{2}{*}{ Species group } & \multirow{2}{*}{$\begin{array}{l}\text { All } \\
\text { grades }\end{array}$} & \multicolumn{4}{|c|}{ Log grade } \\
\hline & & 1 & 2 & 3 & Tie and timber \\
\hline \multicolumn{6}{|l|}{ Softwoods } \\
\hline Jack pine & 416,129 & 10,013 & 31,227 & 374,889 & -- \\
\hline Red pine & 325,587 & 69,624 & 21,801 & 234,162 & -- \\
\hline White pine & 772,302 & 43,123 & 150,740 & 407,436 & 171,003 \\
\hline White spruce & 3,147 & -- & $\ldots$ & 3,147 & $\ldots$ \\
\hline Black spruce & 3,038 & -- & -- & 3,038 & -- \\
\hline Balsam fir & 18,838 & -- & -- & 18,838 & -- \\
\hline Hemlock & 88,210 & -- & -- & 88,210 & -- \\
\hline Tamarack & 34,873 & -- & -- & 34,873 & -- \\
\hline Eastern redcedar & 1,272 & -- & -- & 1,272 & -- \\
\hline Northern white-cedar & 40,436 & -- & -- & 40,436 & -- \\
\hline Other softwoods & 6,238 & - & - & 6,238 & - \\
\hline Total & $1,710,070$ & 122,760 & 203,768 & $1,212,539$ & 171,003 \\
\hline \multicolumn{6}{|l|}{ Hardwoods } \\
\hline White oak & 472,657 & 17,146 & 99,478 & 281,788 & 74,245 \\
\hline Select red oak & $1,106,582$ & 228,337 & 382,697 & 455,855 & 39,693 \\
\hline Other red oak & 772,840 & 25,997 & 87,439 & 431,183 & 228,221 \\
\hline Select hickory & 13,982 & -- & -- & 13,982 & -- \\
\hline Other hickory & 19,733 & -- & -- & 19,733 & -- \\
\hline Basswood & 213,198 & 42,647 & 29,665 & 140,886 & -- \\
\hline Beech & 4,749 & -- & -- & 4,749 & -- \\
\hline Yellow birch & 54,922 & -- & 11,540 & 37,510 & 5,874 \\
\hline Hard maple & 341,476 & 45,170 & 122,460 & 148,122 & 25,724 \\
\hline Soft maple & 563,439 & 50,270 & 127,922 & 374,289 & 10,958 \\
\hline Elm & 109,512 & -- & 49,306 & 28,138 & 32,068 \\
\hline Black ash & 100,226 & 25,210 & 48,126 & 26,890 & -- \\
\hline White \& green ash & 96,736 & 48,662 & 21,278 & 20,637 & 6,161 \\
\hline Cottonwood & 10,173 & -- & -- & 10,173 & -- \\
\hline Willow & 10,825 & -- & 8,623 & 2,202 & -- \\
\hline Hackberry & -- & -- & -- & -- & -- \\
\hline Balsam poplar & -- & -- & -- & -- & -- \\
\hline Bigtooth aspen & 266,184 & 17,801 & 103,607 & 140,464 & 4,310 \\
\hline Quaking aspen & 328,348 & - & 61,978 & 241,880 & 24,488 \\
\hline Paper birch & 55,304 & -- & -- & 55,304 & - \\
\hline River birch & 5,566 & -- & -- & 5,566 & -- \\
\hline Black cherry & 10,963 & -- & -- & 10,963 & -- \\
\hline Black walnut & 1,275 & -- & -- & 1,275 & -- \\
\hline Butternut & 21,233 & -- & 21,233 & -- & -- \\
\hline Other hardwoods & 5,743 & -- & -- & 5,743 & -- \\
\hline Total & $4,585,666$ & 501,240 & $1,175,352$ & $2,457,332$ & 451,742 \\
\hline All species & $6,295,736$ & 624,000 & $1,379,120$ & $3,669,871$ & 622,745 \\
\hline
\end{tabular}




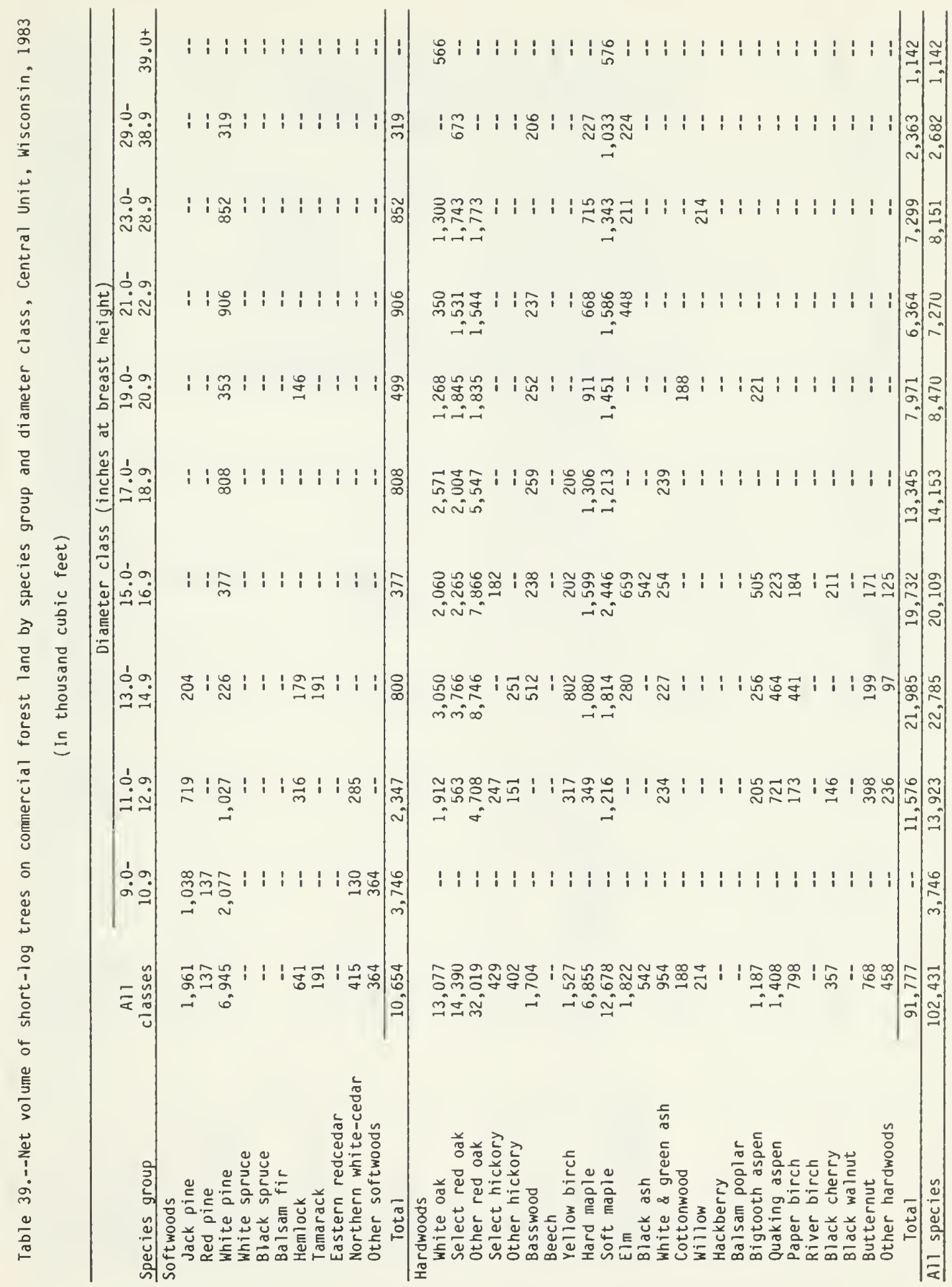




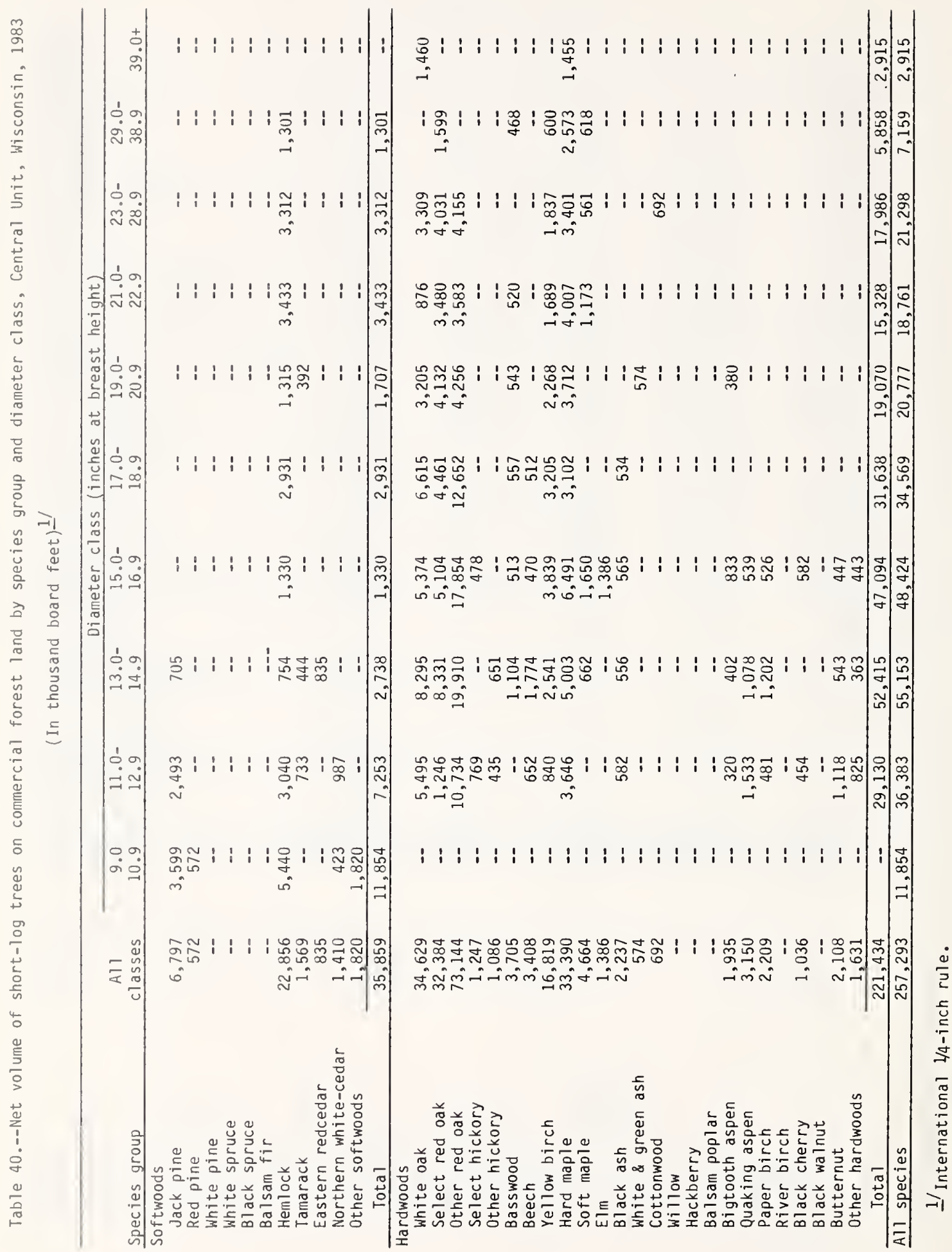


Table $41 .--$ Net annual growth of growing stock

on commercial forest land by softwoods and

hardwoods, Central Unit, Wisconsin, 1967

and 1982

(In thousand cubic feet)

\begin{tabular}{rcc}
\hline Species & $1967 \frac{1 /}{1982}$ \\
\hline Softwoods & 21,400 & 32,720 \\
Hardwoods & 50,600 & 67,456 \\
\cline { 2 - 3 } All species & 72,000 & 100,176 \\
\hline
\end{tabular}

1/Figures have been adjusted from those published after the 1968 survey to conform to 1982 volumes because of changes in survey procedures. 


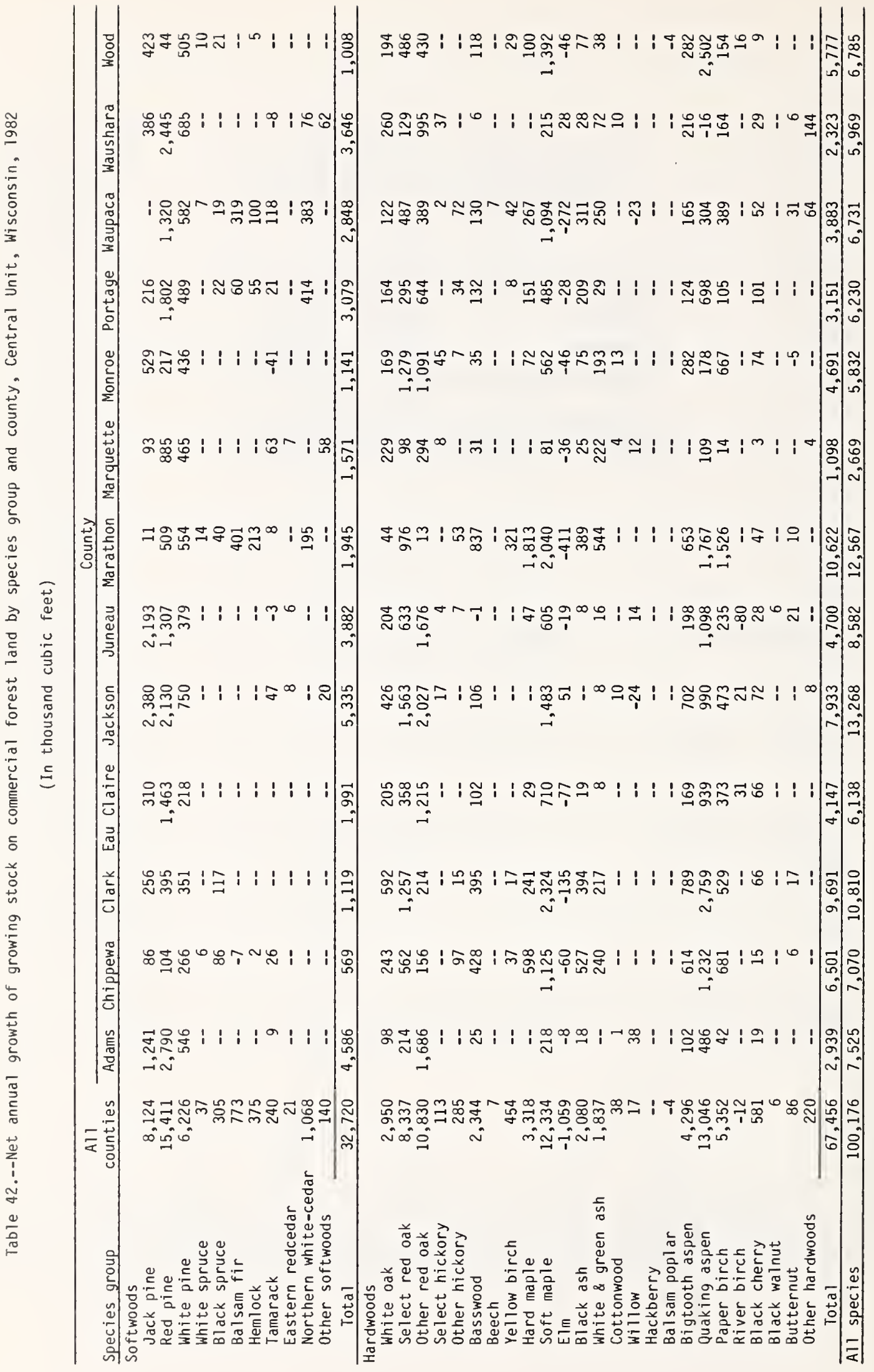




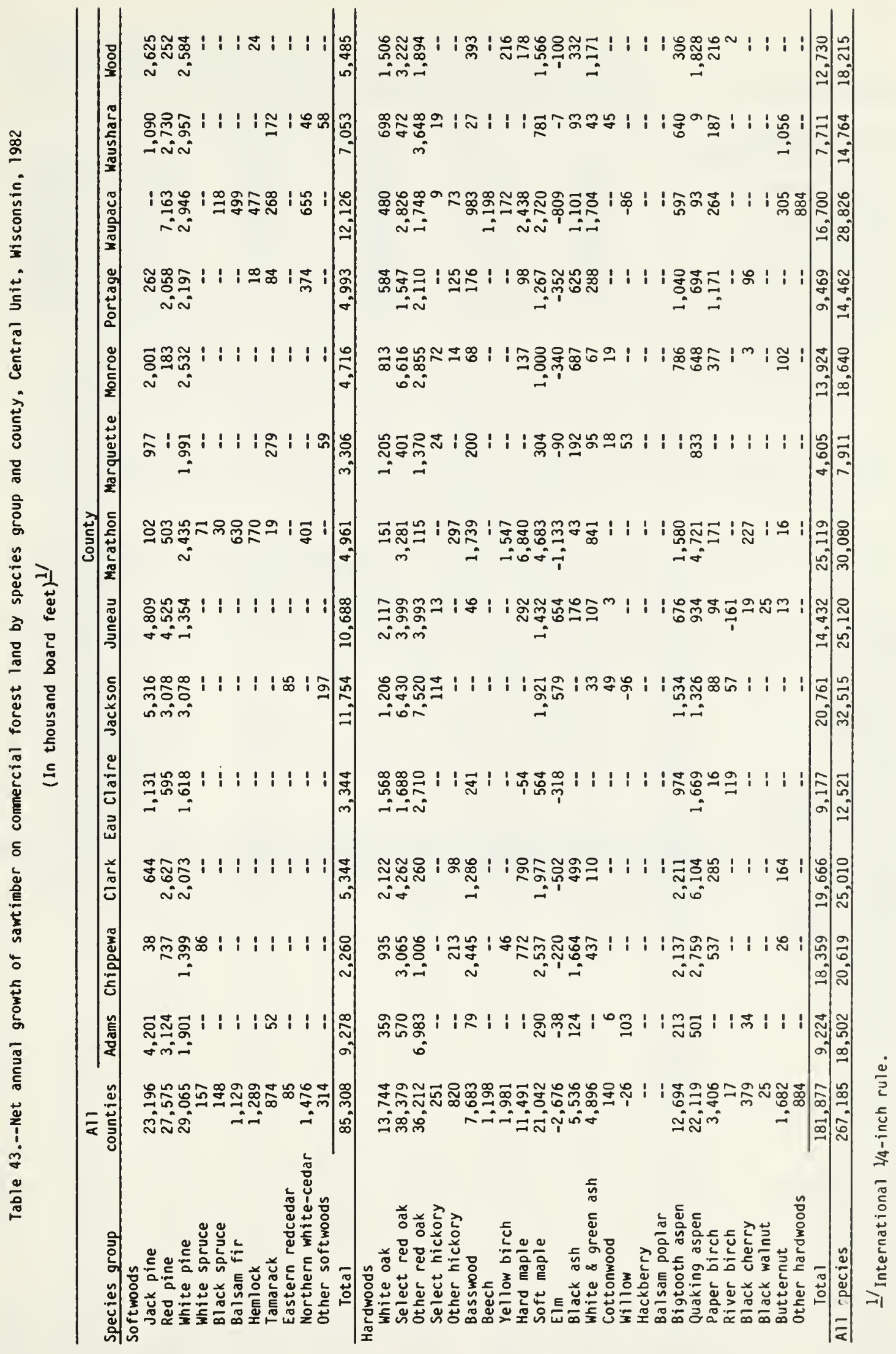


Table 44.--Net annual growth of growing stock on commercial forest land by ownership class and softwoods and hardwoods, Central Unit, Wisconsin, 1982

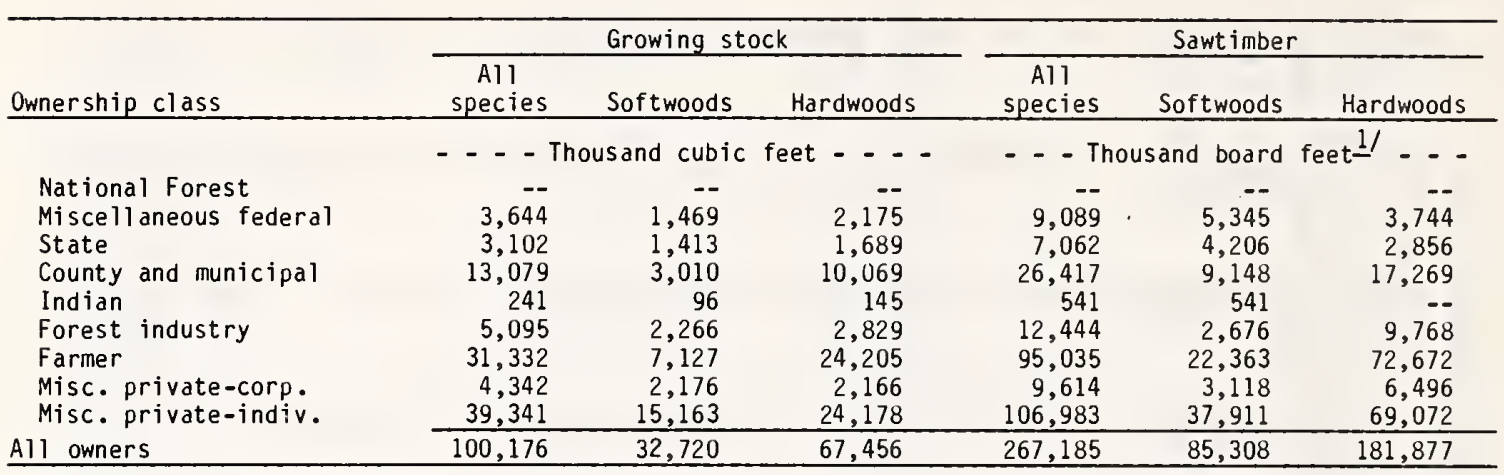

1/ International $1 / 4$-inch rule.

Table 45.--Net annual growth of growing stock on comnercial forest land by species group and forest type, Central Unit, Wisconsin, 1982

(In thousand cubic feet)

\begin{tabular}{|c|c|c|c|c|c|c|c|c|c|}
\hline \multirow[b]{2}{*}{ Species group } & \multirow[b]{2}{*}{$\begin{array}{l}\text { All } \\
\text { types }\end{array}$} & \multicolumn{8}{|c|}{ Forest type } \\
\hline & & $\begin{array}{l}\text { Jack } \\
\text { pine }\end{array}$ & $\begin{array}{l}\text { Red } \\
\text { pine }\end{array}$ & $\begin{array}{l}\text { White } \\
\text { pine }\end{array}$ & $\begin{array}{l}\text { Balsam } \\
\text { fir }\end{array}$ & $\begin{array}{l}\text { White } \\
\text { spruce }\end{array}$ & $\begin{array}{l}\text { Black } \\
\text { spruce }\end{array}$ & $\begin{array}{l}\text { Northern } \\
\text { white- } \\
\text { cedar }\end{array}$ & Tamarack \\
\hline \multicolumn{10}{|l|}{ Softwoods } \\
\hline Jack pine & 8,124 & 5,511 & 206 & 230 & -- & -- & -- & -- & -- \\
\hline Red pine & 15,411 & 763 & 13,240 & 584 & 26 & -- & -- & -- & -- \\
\hline White pine & 6,226 & 110 & 426 & 2,813 & 84 & - & -- & 14 & 49 \\
\hline White spruce & 37 & -- & 7 & - & -- & 10 & -- & -- & -- \\
\hline Black spruce & 305 & -- & 19 & -- & -- & - & 142 & 13 & -- \\
\hline Balsam fir & 773 & -- & -- & -- & 231 & -- & -- & 153 & -- \\
\hline Hemlock & 375 & -- & -- & -- & -- & - & $=$ & -5 & -- \\
\hline Tamarack & 240 & -- & -- & 15 & -- & -- & 2 & -12 & 334 \\
\hline Eastern redcedar & 21 & 8 & -- & -- & -- & -- & -- & - & -- \\
\hline Northern white-cedar & 1,068 & -- & -- & $=$ & -- & $\cdots$ & - & 762 & 13 \\
\hline Other softwoods & 140 & -- & 82 & $=-$ & -- & $=-$ & - & $\cdots$ & -- \\
\hline Total & 32,720 & 6,392 & 13,980 & 3,642 & 341 & 10 & 144 & 925 & 396 \\
\hline \multicolumn{10}{|l|}{ Hardwoods } \\
\hline White oak & 2,950 & 8 & 10 & 43 & -- & -- & -- & -- & -- \\
\hline Select red oak & 8,337 & 15 & 11 & 20 & 6 & -- & -- & 2 & -- \\
\hline Other red oak & 10,830 & 461 & 121 & 194 & -- & -- & -- & 2 & -- \\
\hline Select hickory & 113 & -- & - & 22 & -- & - & -- & -- & -- \\
\hline Other hickory & 285 & -- & -- & -- & -- & -- & -- & - & -- \\
\hline Basswood & 2,344 & -- & 2 & -- & 4 & -- & -- & 3 & -- \\
\hline Beech & 7 & -- & -3 & -- & -- & -. & -- & -- & -- \\
\hline Yellow birch & 454 & -- & -- & -11 & -- & -- & -. & -2 & 5 \\
\hline Hard maple & 3,318 & -- & 8 & 23 & -- & -- & -- & -- & -- \\
\hline Soft maple & 12,334 & -- & 1 & 251 & 8 & -- & -- & -2 & 24 \\
\hline Elm & $-1,059$ & -- & -- & -23 & 8 & -- & -- & -17 & 5 \\
\hline Black ash & 2,080 & -- & -- & 14 & 13 & -- & - & 9 & -- \\
\hline White \& green ash & 1,837 & $\rightarrow$ & 9 & -- & -- & -- & -- & -- & -- \\
\hline Cottonwood & 38 & 9 & - & -- & -- & -- & -- & -- & -- \\
\hline Willow & 17 & -- & -- & -- & -- & -- & -- & -- & -- \\
\hline Hackberry & -- & -- & -- & -- & -- & -- & -- & -- & -- \\
\hline Balsam poplar & -4 & -- & -- & -- & -- & -- & -- & -- & -- \\
\hline Bigtooth aspen & 4,296 & 38 & -8 & 125 & -- & -- & $\ldots$ & -- & 14 \\
\hline Quaking aspen & 13,046 & 95 & 2 & 743 & -- & -- & -- & -47 & 194 \\
\hline Paper birch & 5,352 & 12 & -- & 47 & 18 & -- & -- & 12 & 18 \\
\hline River birch & -12 & -- & -- & -- & -- & -- & -- & -- & -- \\
\hline Black cherry & 581 & -- & -- & 66 & -- & -- & -- & -- & -- \\
\hline Black walnut & 6 & -- & -- & -- & -- & -- & -- & - & -- \\
\hline Butternut & 86 & -- & -- & -- & -- & -- & -- & -- & -- \\
\hline Other hardwoods & 220 & -- & - & - & -- & -- & -- & -- & -- \\
\hline Total & 67,456 & 638 & 153 & 1,514 & 57 & -- & -- & -40 & 260 \\
\hline All species & 100,176 & 7,030 & 14,133 & 5,156 & 398 & 10 & 144 & 885 & 656 \\
\hline
\end{tabular}


(Table 45 continued)

\begin{tabular}{|c|c|c|c|c|c|c|c|}
\hline \multirow[b]{2}{*}{ Species group } & \multicolumn{7}{|c|}{ Forest type } \\
\hline & $\begin{array}{c}\text { Oak- } \\
\text { hickory }\end{array}$ & $\begin{array}{l}\text { Elm-ash- } \\
\text { soft maple }\end{array}$ & $\begin{array}{l}\text { Maple- } \\
\text { birch }\end{array}$ & Aspen & $\begin{array}{l}\text { Paper } \\
\text { birch }\end{array}$ & Exotic & $\begin{array}{c}\text { Non- } \\
\text { stocked }\end{array}$ \\
\hline \multicolumn{8}{|l|}{ Softwoods } \\
\hline Jack pine & 1,378 & -2 & 210 & 534 & 53 & -- & 4 \\
\hline Red pine & 219 & 13 & 410 & 72 & B4 & -- & -- \\
\hline White pine & 975 & 379 & 1,003 & 193 & 180 & -- & -- \\
\hline White spruce & -- & 14 & 6 & -- & -- & -- & -- \\
\hline Black spruce & -- & 19 & 5 & 107 & -- & -- & -- \\
\hline Balsam fir & 26 & 69 & 257 & 25 & 12 & -- & -- \\
\hline Hemlock & 5 & 55 & 308 & 12 & -- & -- & - \\
\hline Tamarack & -- & -115 & -- & 11 & -12 & -- & 17 \\
\hline Eastern redcedar & 13 & - & -- & -- & -- & -- & - \\
\hline Northern white-cedar & 9 & 107 & 123 & -- & 54 & -- & -- \\
\hline Other softwoods & 20 & - & -- & -- & -- & $3 B$ & - \\
\hline Total & 2,645 & 539 & 2,322 & 954 & 371 & $3 B$ & 21 \\
\hline \multicolumn{8}{|l|}{ Hardwoods } \\
\hline White oak & 2,056 & 155 & 332 & 215 & 123 & -- & 8 \\
\hline Select red oak & 6,002 & 165 & 1,256 & 727 & 129 & -- & 4 \\
\hline Other red oak & $B, 573$ & 166 & 439 & 792 & 27 & -- & 55 \\
\hline Select hickory & 71 & 2 & -- & -- & 18 & -- & -- \\
\hline Other hickory & 94 & -- & 130 & 61 & -- & -- & -- \\
\hline Basswood & 209 & 517 & 1,491 & 84 & 17 & -- & 17 \\
\hline Beech & -- & -- & 10 & -- & -- & -- & -- \\
\hline Yellow birch & 16 & 71 & 373 & -4 & 6 & -- & -- \\
\hline Hard maple & 250 & 18 & 2,703 & 267 & 49 & -- & -- \\
\hline Soft maple & 1,916 & 3,593 & 3,415 & 2,916 & 212 & -- & $\ldots$ \\
\hline Elm & -54 & -597 & -334 & -57 & 49 & -- & -39 \\
\hline Black ash & $3 B$ & 1,436 & 185 & 314 & 52 & -- & 19 \\
\hline White \& green ash & 350 & 255 & 1,142 & 60 & 21 & -- & -- \\
\hline Cottonwood & 19 & - & 1 & 5 & 4 & -- & -- \\
\hline Will ow & -- & -60 & 12 & 52 & 13 & -- & -- \\
\hline Hackberry & -- & -- & -- & -- & -- & -- & -- \\
\hline Balsam poplar & -- & -- & -- & -4 & -- & -- & -- \\
\hline Bigtooth aspen & 1,061 & 2 & 558 & 2,347 & 159 & -- & -- \\
\hline Quaking aspen & B22 & 544 & 890 & B,B83 & 918 & -- & 2 \\
\hline Paper birch & 1,075 & 213 & 745 & 1,279 & 1,919 & -- & 14 \\
\hline River birch & -2 & -10 & -- & -- & -- & -- & $\cdots$ \\
\hline Black cherry & 239 & 47 & 154 & 56 & 19 & -- & -- \\
\hline Black walnut & -- & -- & 6 & -- & -- & -- & -- \\
\hline Butternut & 44 & -- & 25 & 7 & 10 & -- & -- \\
\hline Other hardwoods & 13 & 64 & 4 & 139 & -- & -- & -- \\
\hline Total & 22,792 & $6,5 \mathrm{Bl}$ & 13,537 & 18,139 & 3,745 & -- & BO \\
\hline All species & 25,437 & 7,120 & 15,859 & 19,093 & 4,116 & 38 & 101 \\
\hline
\end{tabular}


Table 46.--Net annual growth of sawtimber on commercial forest land by species group and forest type, Central Unit, Wisconsin, 1982

(In thousand board feet) 1 '

\begin{tabular}{|c|c|c|c|c|c|c|c|c|c|}
\hline \multirow[b]{2}{*}{ Species group } & \multirow[b]{2}{*}{$\begin{array}{c}\text { All } \\
\text { types }\end{array}$} & \multicolumn{8}{|c|}{ Forest type } \\
\hline & & $\begin{array}{l}\text { Jack } \\
\text { pine }\end{array}$ & $\begin{array}{l}\text { Red } \\
\text { pine }\end{array}$ & $\begin{array}{l}\text { White } \\
\text { pine }\end{array}$ & $\begin{array}{c}\text { 8al sam } \\
\text { fir }\end{array}$ & $\begin{array}{l}\text { White } \\
\text { spruce }\end{array}$ & $\begin{array}{l}81 \text { ack } \\
\text { spruce }\end{array}$ & $\begin{array}{l}\text { Northern } \\
\text { white- } \\
\text { cedar }\end{array}$ & Tamarack \\
\hline \multicolumn{10}{|l|}{ Softwoods } \\
\hline Jack pine & 23,196 & 13,990 & 652 & 364 & -- & -- & -- & -- & -- \\
\hline Red pine & 27,575 & 1,002 & 23,223 & 1,211 & 148 & -- & -- & -- & -. \\
\hline White pine & 29,065 & 749 & 775 & 12,967 & 492 & -- & -- & 34 & 229 \\
\hline White spruce & 157 & -- & - & - & -- & -- & -- & -- & - \\
\hline 81 ack spruce & 148 & -- & -- & -- & -- & -- & -- & -- & -- \\
\hline $8 a l s a m$ fir & 1,129 & -. & -- & -- & 291 & -- & -- & 152 & -- \\
\hline Hemlock & 1,289 & -- & -- & -- & - & -- & -- & -18 & -- \\
\hline Tamarack & 874 & -- & -- & 140 & -- & - & - & -2 & 562 \\
\hline Eastern redcedar & 85 & 85 & -- & -- & -- & -- & -- & - & -- \\
\hline Northern white-cedar & 1,476 & -- & -- & -- & $-\infty$ & $\rightarrow$ & -- & 859 & -- \\
\hline Other softwoods & 314 & -- & 314 & -- & -- & - & -- & -- & -- \\
\hline Total & 85,308 & 15,826 & 24,964 & 14,682 & 931 & $\cdots$ & -- & 1,025 & 791 \\
\hline \multicolumn{10}{|l|}{ Hardwoods } \\
\hline White oak & 13,744 & -- & 96 & 115 & -- & -- & -- & -- & -- \\
\hline Select red oak & 38,379 & 173 & -16 & 72 & 28 & -- & -- & 12 & -- \\
\hline Other red oak & 36,212 & 649 & 364 & 536 & -- & -- & -- & 10 & -- \\
\hline Select hickory & 251 & -- & -- & -- & -- & -- & -- & -- & -- \\
\hline Other hickory & 820 & -- & -- & -- & -- & -- & -- & -- & -- \\
\hline Basswood & 7,683 & -- & 12 & -- & 23 & -- & -- & 15 & -- \\
\hline Beech & 1,198 & -- & 1,079 & -- & -- & -- & -- & -- & -- \\
\hline Yellow birch & 1,981 & -- & - & -80 & -- & -- & -- & -- & -- \\
\hline Hard maple & 11,491 & -- & 890 & 156 & - & -- & -- & -- & -- \\
\hline Soft maple & 21,042 & -- & 1 & 147 & - & - & -- & 9 & 11 \\
\hline Elm & $-2,676$ & -- & -- & -68 & -- & -- & -- & -49 & -- \\
\hline 81 ack ash & 5,536 & -- & -- & 149 & 93 & -- & -- & 71 & -- \\
\hline White \& green ash & 4,896 & -- & 37 & - & -- & -- & -- & -- & -- \\
\hline Cottonwood & 140 & -- & -- & -- & -- & -- & -- & -- & -- \\
\hline Willow & -26 & -- & -- & -- & -- & -- & -- & -- & -- \\
\hline Hackberry & -- & -- & -- & -- & -- & -- & -- & -- & -- \\
\hline 8alsam poplar & -- & - & -- & -- & -- & -- & -- & -- & -- \\
\hline 8igtooth aspen & 12,694 & 53 & -- & -43 & -- & -- & -- & -- & 33 \\
\hline Quaking aspen & 22,119 & -- & -- & 18 & -- & -- & -- & -15 & -- \\
\hline Paper birch & 3,406 & -- & -- & -58 & -- & -- & -- & 5 & -- \\
\hline River birch & 17 & -- & -- & -- & -- & -- & -- & -- & -- \\
\hline 81 ack cherry & 379 & -- & -- & -- & -- & -- & -- & -- & -- \\
\hline Black walnut & 25 & -- & -- & -- & -- & -- & -- & -- & -- \\
\hline 8utternut & 1,682 & -- & -- & -- & -- & -- & -- & -- & -- \\
\hline Other hardwoods & $\begin{array}{r}184 \\
\end{array}$ & - & -- & - & - & $\ldots$ & -- & -- & -- \\
\hline Total & 181,877 & 875 & 2,463 & 944 & 144 & -- & -- & 58 & 44 \\
\hline A11 species & 267,185 & 16,701 & 27,427 & 15,626 & 1,075 & -- & -- & 1,083 & 835 \\
\hline
\end{tabular}


(Table 46 continued)

\begin{tabular}{|c|c|c|c|c|c|c|c|}
\hline \multirow[b]{2}{*}{ Species group } & \multicolumn{7}{|c|}{ Forest type } \\
\hline & $\begin{array}{c}\text { Oak- } \\
\text { hickory }\end{array}$ & $\begin{array}{l}\text { Elm-ash- } \\
\text { soft maple }\end{array}$ & $\begin{array}{l}\text { Maple- } \\
\text { birch }\end{array}$ & Aspen & $\begin{array}{l}\text { Paper } \\
\text { birch }\end{array}$ & Exotic & $\begin{array}{l}\text { Non- } \\
\text { stocked }\end{array}$ \\
\hline \multicolumn{8}{|l|}{ Softwoods } \\
\hline Jack pine & 4,714 & 44 & 425 & 2,896 & 111 & -- & -- \\
\hline Red pine & 716 & 74 & 348 & 226 & 627 & -- & -- \\
\hline White pine & 5,050 & 1,741 & 5,086 & 867 & 1,075 & -- & -- \\
\hline White spruce & -- & 71 & 86 & -- & -- & -- & -- \\
\hline Black spruce & -- & 118 & 30 & -- & -- & -- & -- \\
\hline Balsam fir & -- & 219 & 423 & 44 & -- & -- & -- \\
\hline Hemlock & 24 & 12 & 1,208 & 63 & -- & -- & -- \\
\hline Tamarack & -- & 11 & -- & 68 & -5 & - & 100 \\
\hline Eastern redcedar & -. & $=-$ & $=-$ & -- & -- & -. & -- \\
\hline Northern white-cedar & - & 196 & 345 & -- & 76 & -- & -- \\
\hline Other softwoods & -- & -- & -- & -- & -- & -- & -- \\
\hline Total & 10,504 & 2,486 & 7,951 & 4,164 & 1,884 & -- & 100 \\
\hline \multicolumn{8}{|l|}{ Hardwoods } \\
\hline White oak & 9,545 & 591 & 1,394 & 556 & 1,426 & -- & 21 \\
\hline Select red oak & 26,837 & 1,035 & 6,013 & 3,466 & 740 & -- & 19 \\
\hline Other red oak & 28,584 & 747 & 1,524 & 3,572 & 183 & -- & 43 \\
\hline Select hickory & 196 & 9 & -- & -- & 46 & -- & -- \\
\hline Other hickory & 170 & -- & 650 & -- & -- & -- & -- \\
\hline Basswood & 817 & 748 & 5,552 & 415 & 101 & -- & -- \\
\hline Beech & -- & -- & 119 & -- & -- & -- & -- \\
\hline Yellow birch & 65 & 314 & 1,614 & -- & 68 & -- & -- \\
\hline Hard maple & 511 & 49 & 9,749 & 37 & 99 & -- & -- \\
\hline Soft maple & 3,433 & 7,214 & 7,375 & 2,350 & 502 & -- & -- \\
\hline Elm & 313 & $-2,283$ & -600 & 340 & -159 & -- & -170 \\
\hline 81 ack ash & 31 & 4,134 & 804 & 130 & 124 & -- & -- \\
\hline White \& green ash & 1,352 & 1,602 & 1,787 & -- & 118 & -- & -- \\
\hline Cottonwood & 88 & 3 & 6 & 24 & 19 & -- & -- \\
\hline Willow & -- & -238 & 53 & 103 & 56 & -- & -- \\
\hline Hackberry & -- & - & -- & -- & -- & -- & -- \\
\hline 8alsam poplar & -- & -- & -- & -- & -- & -- & $\ldots$ \\
\hline 8igtooth aspen & 2,881 & -- & 1,355 & 7,653 & 762 & -- & -- \\
\hline Quaking aspen & 2,638 & 2,207 & 3,346 & 13,410 & 515 & -- & -- \\
\hline Paper birch & 336 & 317 & 1,055 & 253 & 1,498 & -- & -- \\
\hline River birch & 15 & 2 & -. & -- & -. & -- & -- \\
\hline 81 ack cherry & 148 & -- & 206 & -- & 25 & -- & -- \\
\hline 81 ack walnut & -- & $=-$ & 25 & -- & -- & -- & $=$ \\
\hline 8utternut & 1,290 & -- & 392 & -- & -- & -- & -- \\
\hline Other hardwoods & -- & 884 & -- & -- & -- & -- & -- \\
\hline Total & 79,250 & 17,335 & 42,419 & 32,309 & 6,123 & -- & -87 \\
\hline All species & 89,754 & 19,821 & 50,370 & 36,473 & 8,007 & -- & 13 \\
\hline
\end{tabular}




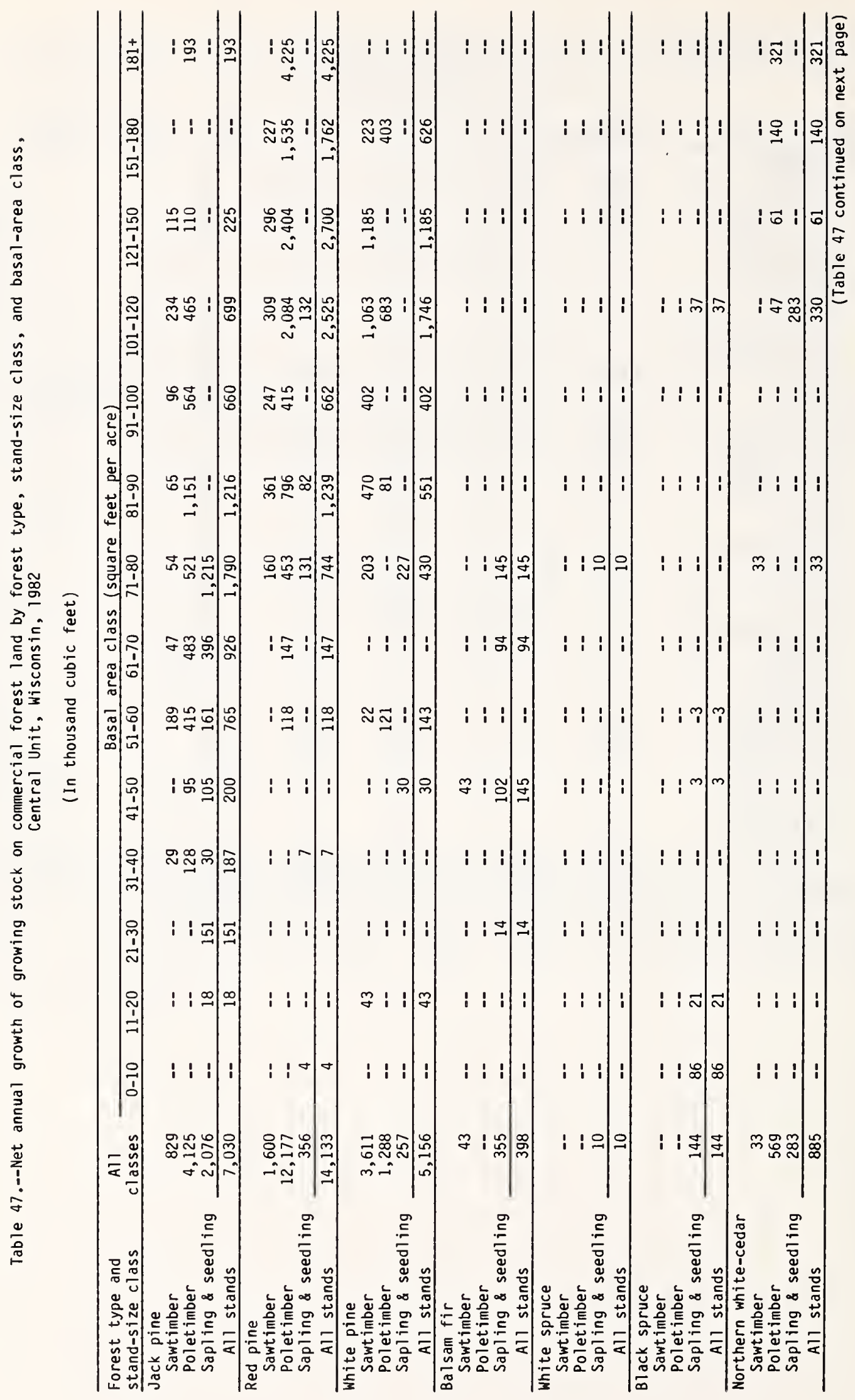




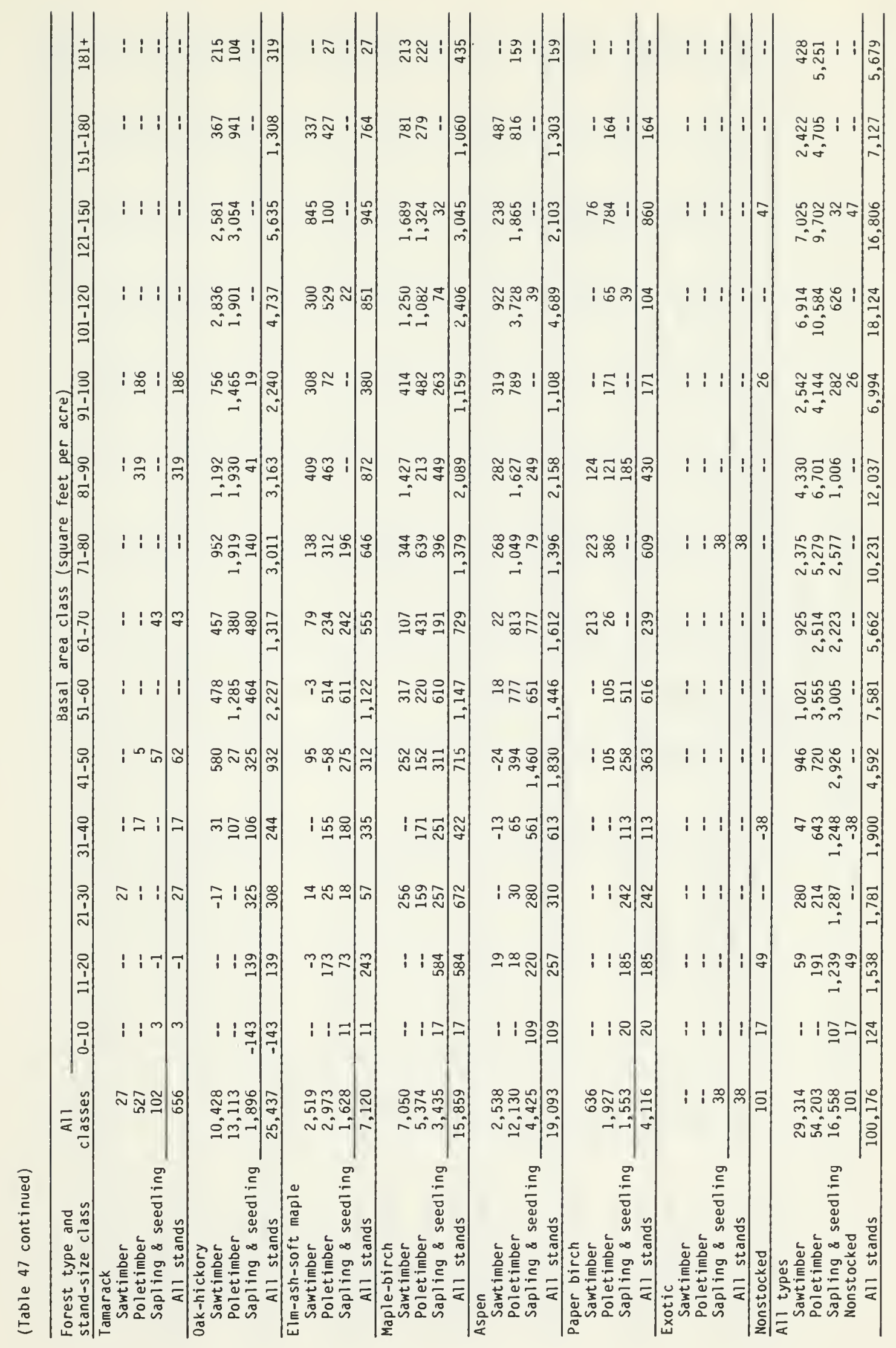




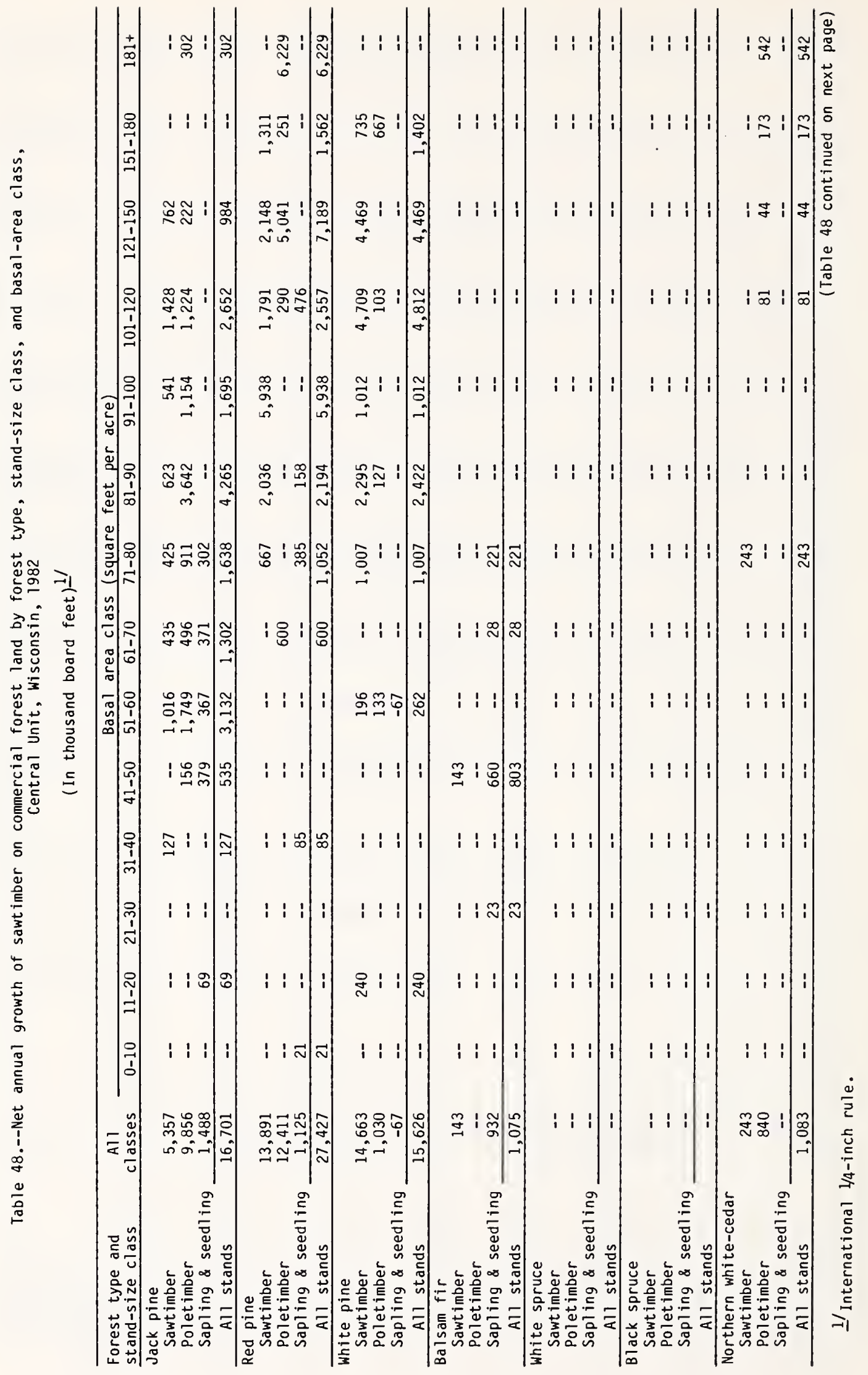




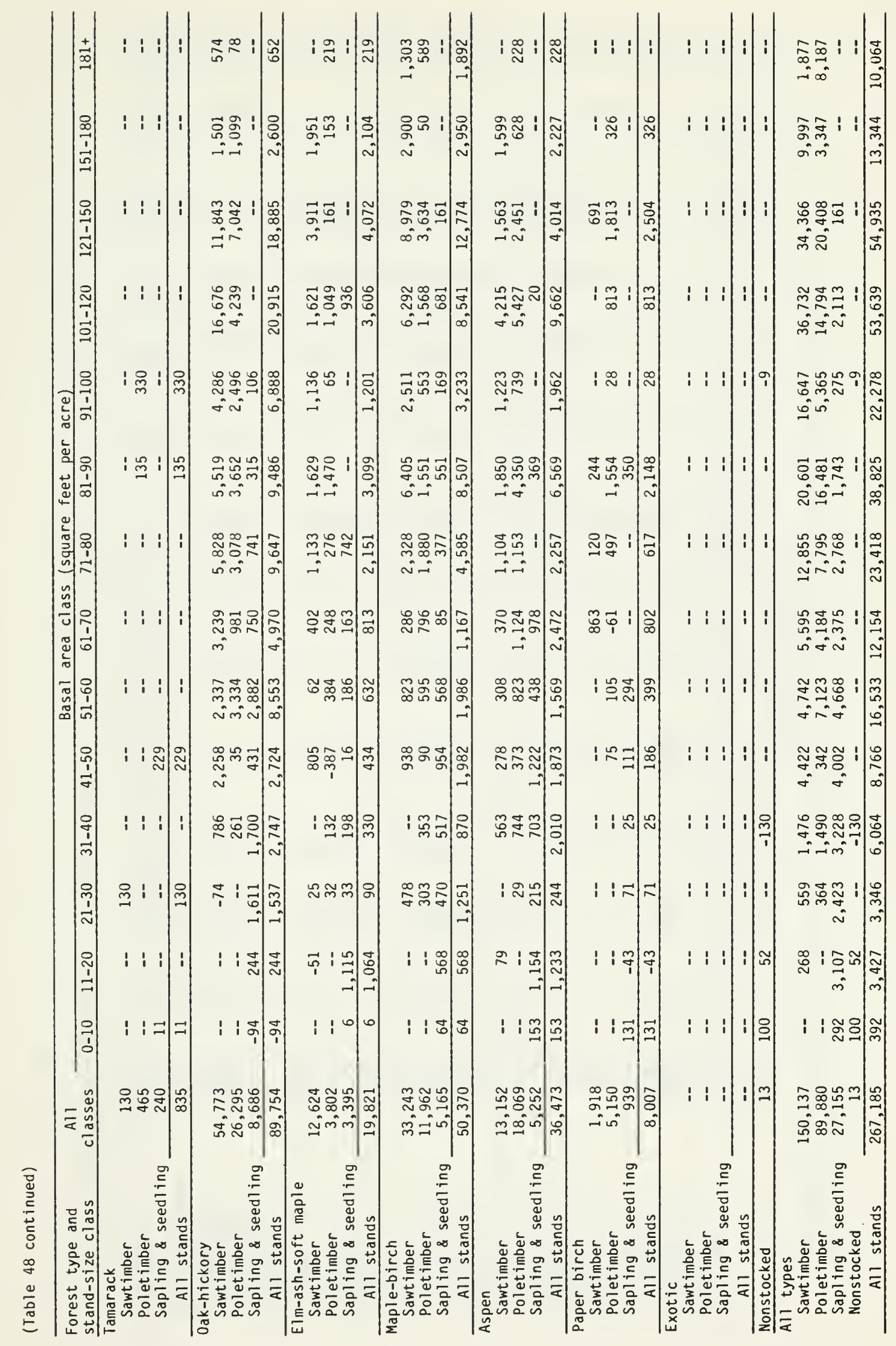




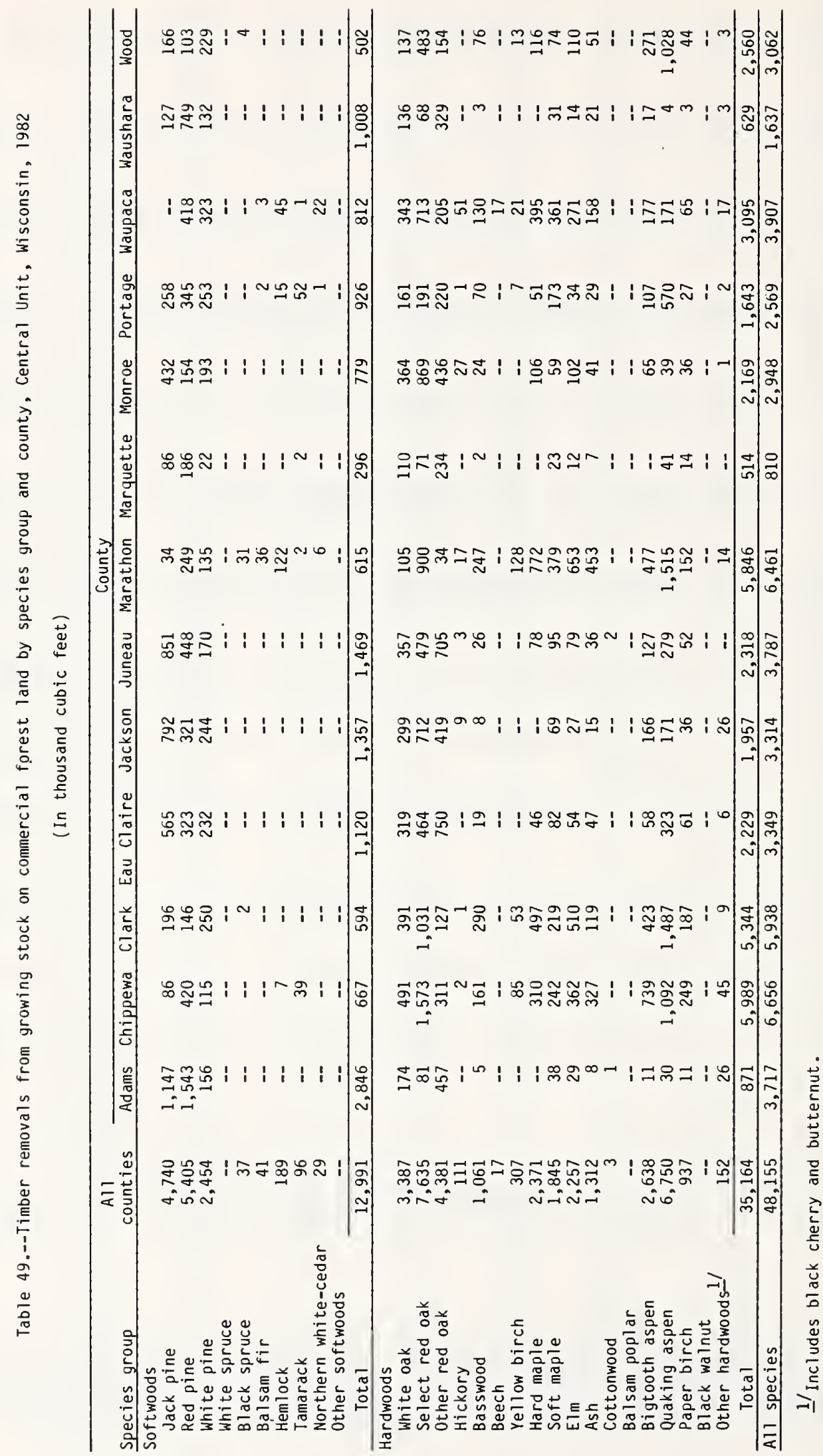




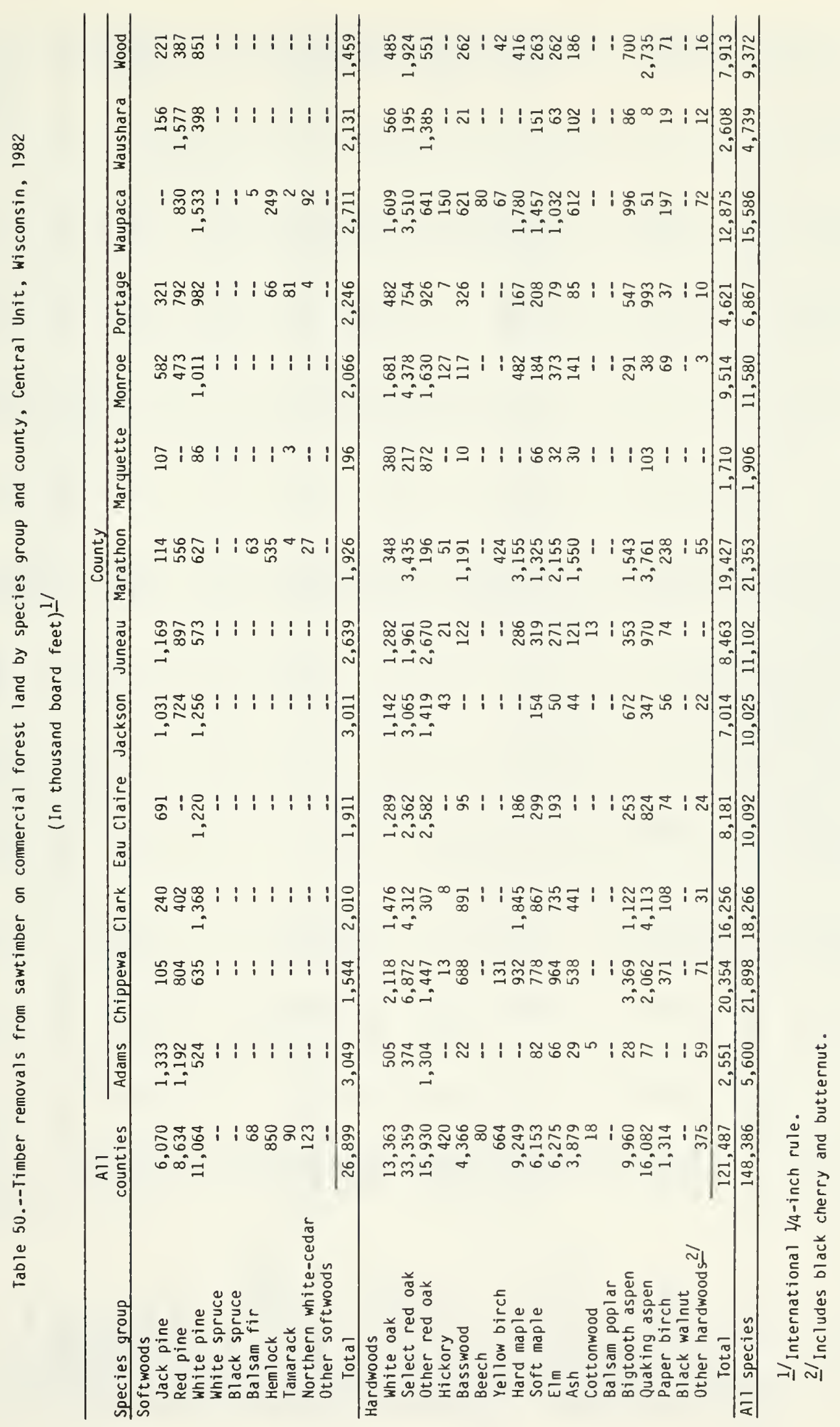




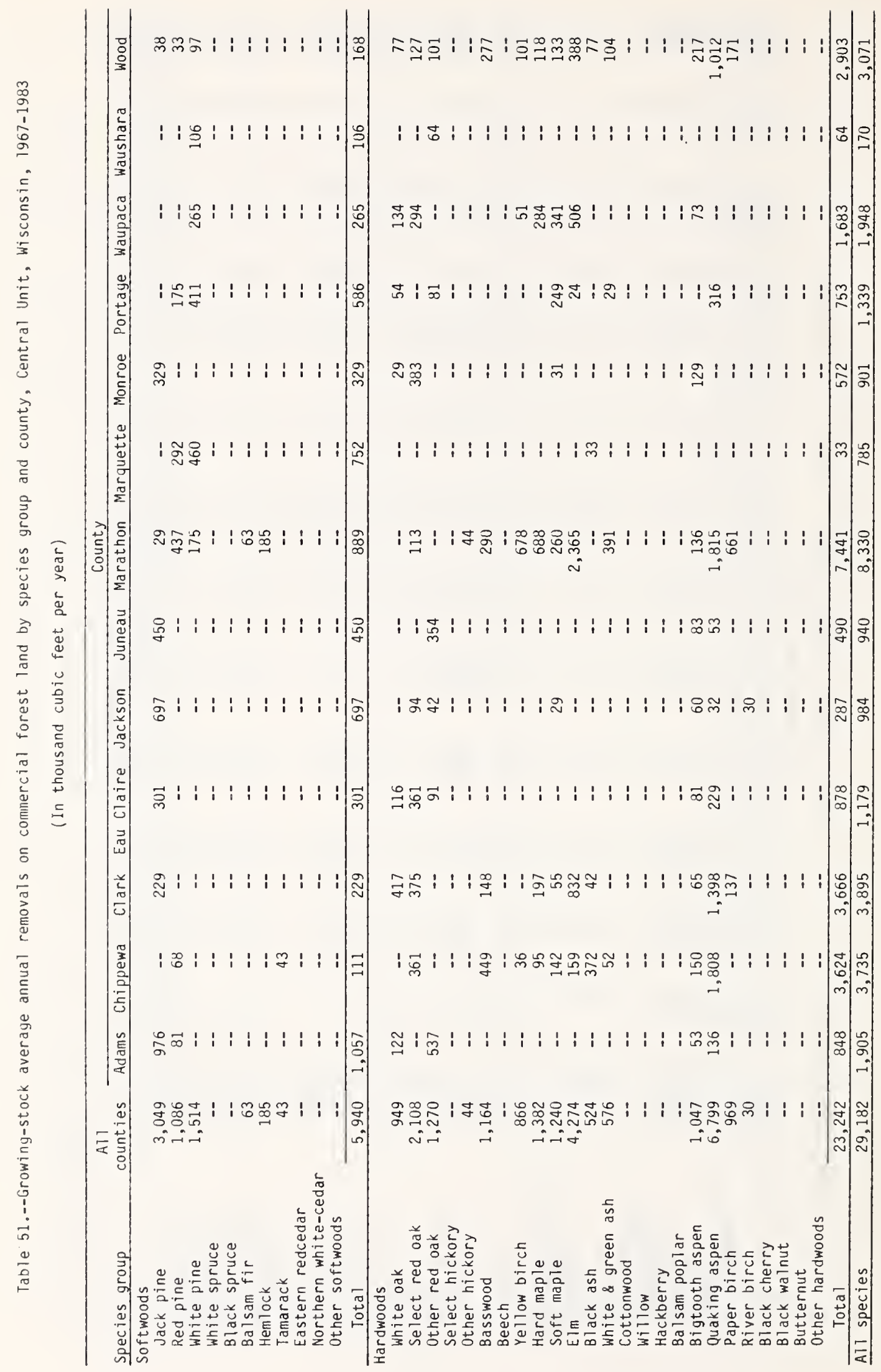




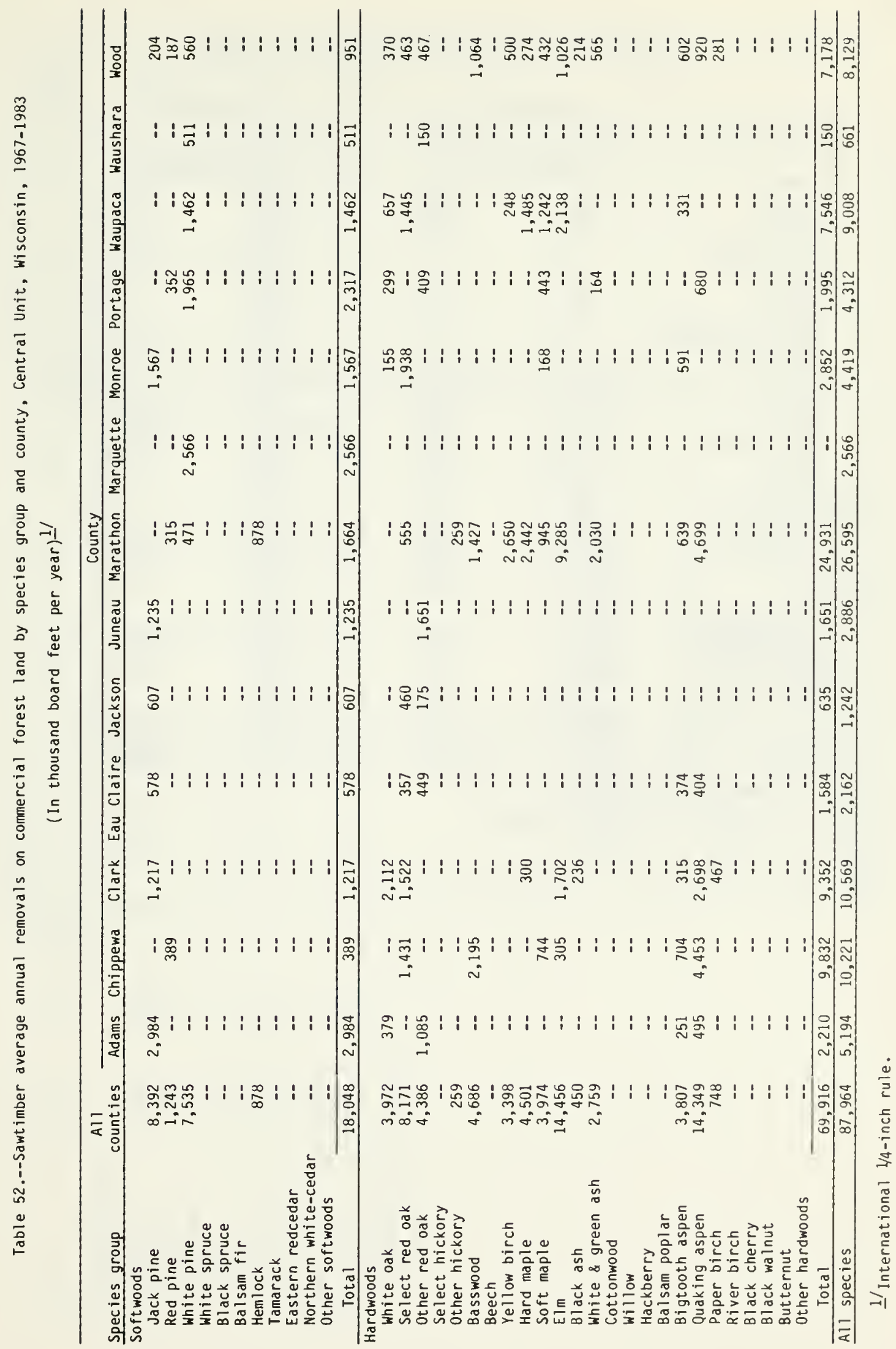


Table 53.--Timber removals from growing stock and sawtimber on commercial forest land by species yroup, Central Unit, Wisconsin, 1967 and 1982

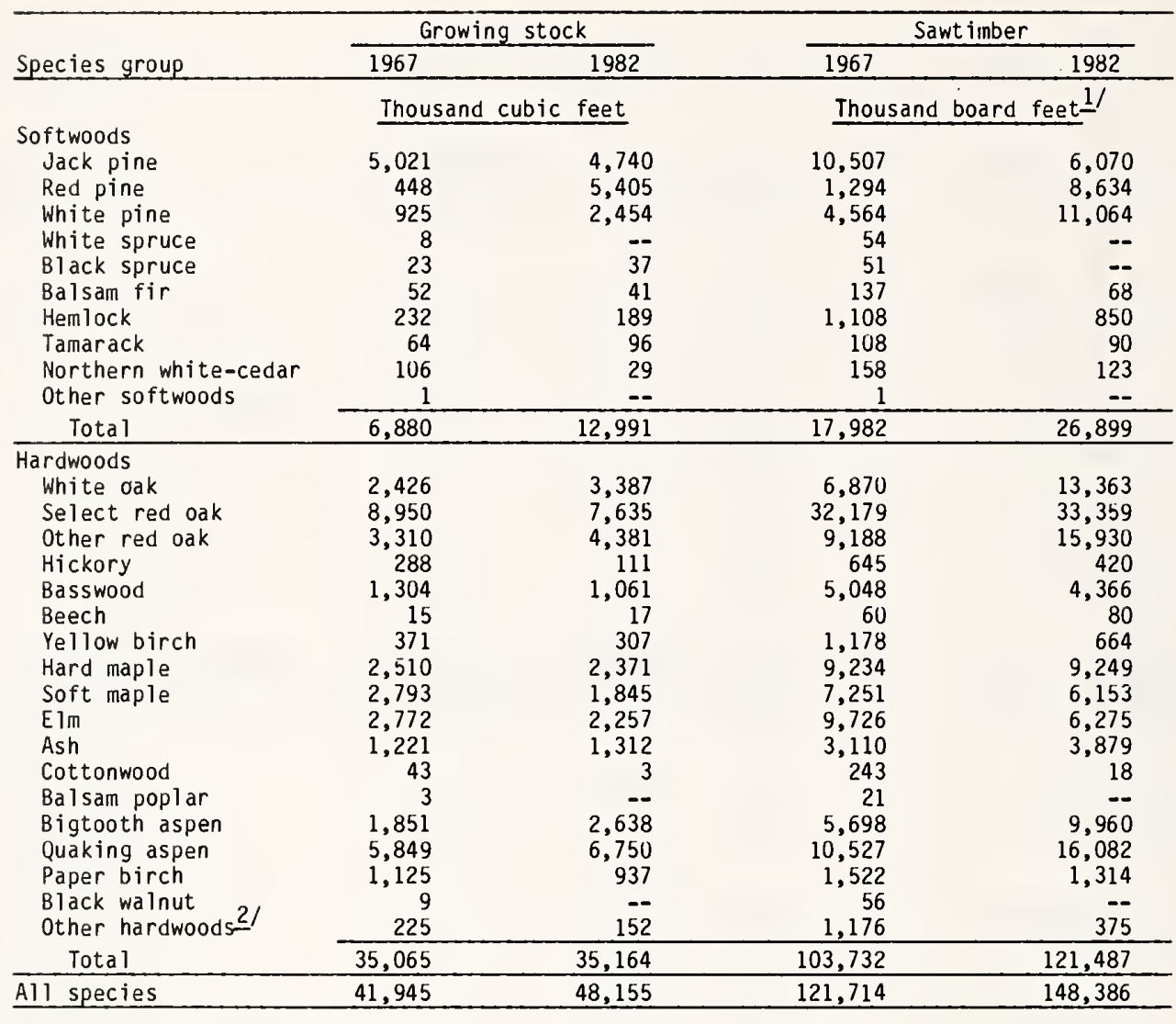

1/International 1/4-inch rule.

2/Includes black cherry and butternut. 

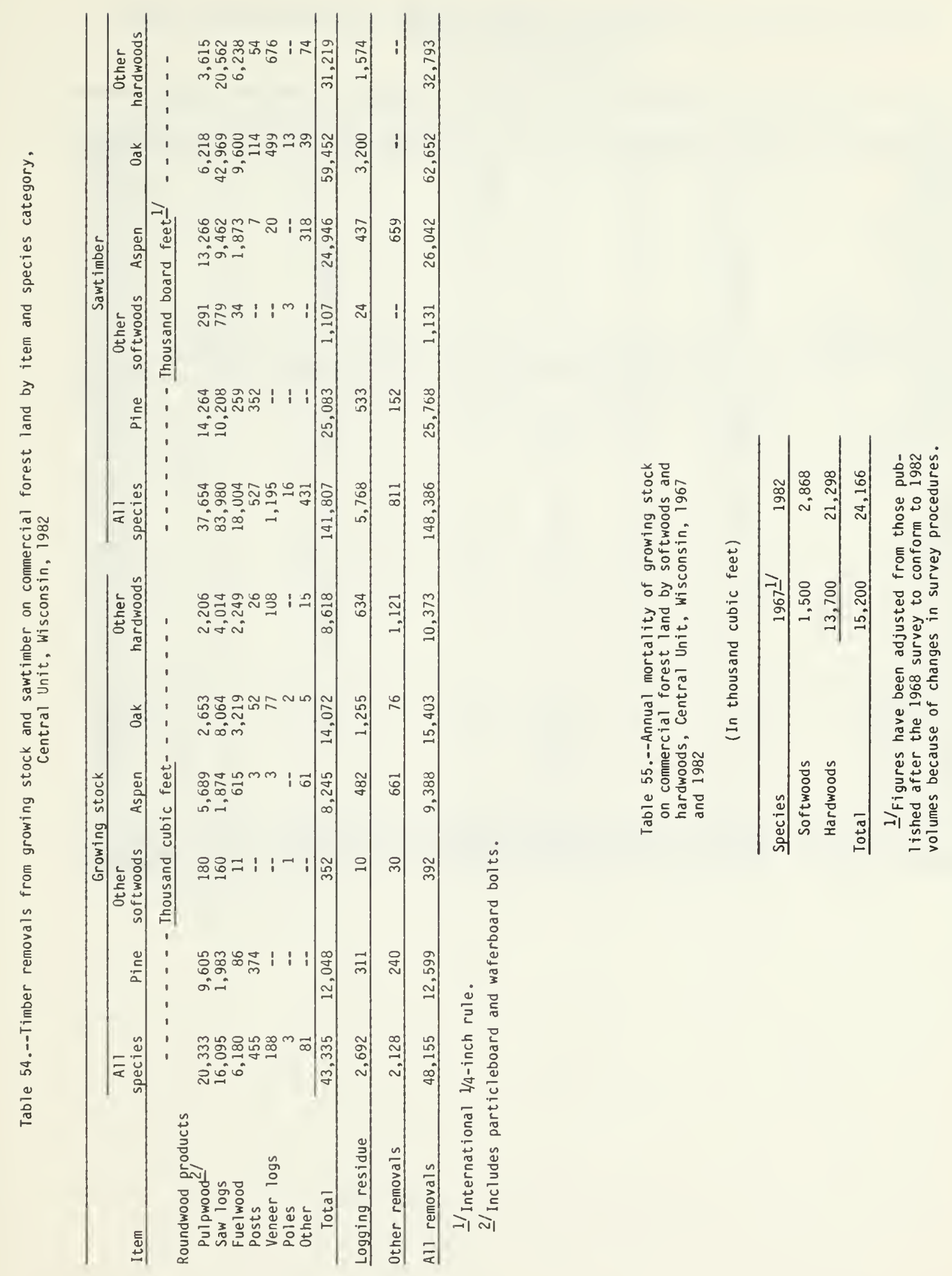
Table 56.--Annual mortality of growing stock on commercial forest land by species group and cause, Central Unit, Wisconsin, 1982

(In thousand cubic feet)

\begin{tabular}{|c|c|c|c|c|c|c|c|c|}
\hline \multirow[b]{2}{*}{ Species group } & \multirow[b]{2}{*}{$\begin{array}{c}\text { All } \\
\text { causes }\end{array}$} & \multicolumn{7}{|c|}{ Cause } \\
\hline & & Insects & Disease & Fire & Animals & Weather & Suppression & $\begin{array}{l}\text { Unknown } \\
\text { and other }\end{array}$ \\
\hline \multicolumn{9}{|l|}{ Softwoods } \\
\hline Jack pine & 1,590 & 4 & 86 & 228 & 1 & 153 & 31 & 1,087 \\
\hline Red pine & 10 & -- & -- & 10 & -- & -- & -- & -- \\
\hline White pine & 310 & 12 & 47 & -- & -- & - & -- & 251 \\
\hline White spruce & 1 & -- & -- & -- & -- & -- & -- & 1 \\
\hline Black spruce & -- & -- & -- & -- & -- & -- & -- & - \\
\hline Balsam fir & 265 & 13 & 2 & -- & 1 & 38 & -- & 211 \\
\hline Hemlock & 204 & -- & 5 & -- & 7 & 41 & -. & 151 \\
\hline Tamarack & 427 & -- & 34 & -- & -- & 132 & -- & 261 \\
\hline Eastern redcedar & -- & -- & -- & -- & -- & -- & -- & -- \\
\hline Northern white-cedar & 52 & -- & -- & -- & -- & -. & -. & 52 \\
\hline Other softwoods & 9 & -- & $\ldots$ & - & 1 & 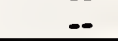 & - & 8 \\
\hline Total & 2,868 & 29 & 174 & 238 & 10 & 364 & 31 & 2,022 \\
\hline \multicolumn{9}{|l|}{ Hardwoods } \\
\hline White oak & 515 & -- & 10 & -- & 4 & 17 & 2 & 482 \\
\hline Select red oak & 1,411 & -. & 122 & -- & $\ldots$ & 107 & 15 & 1,167 \\
\hline other red oak & 1,466 & 1 & 197 & -- & 1 & 132 & 1 & 1,134 \\
\hline Select hickory & 1 & $-\infty$ & 1 & -- & $\ldots$ & -- & $\ldots$ & -- \\
\hline Other hickory & 28 & - & -- & - & -- & 15 & - & 13 \\
\hline Basswood & 374 & -- & 1 & -- & -- & 18 & -- & 355 \\
\hline Beech & 13 & -- & 7 & -- & -- & $\ldots$ & - & 6 \\
\hline Yellow birch & 259 & -- & 3 & -- & -- & -- & -- & 256 \\
\hline Hard maple & 330 & -- & 11 & -- & 3 & 8 & 16 & 292 \\
\hline Soft maple & 1,047 & 1 & 90 & 45 & 4 & 20 & 7 & 880 \\
\hline Elm & 4,193 & 200 & 1,061 & -- & 6 & - & -- & 2,926 \\
\hline Black ash & 219 & -- & - & -. & -- & 27 & -- & 192 \\
\hline White \& green ash & 95 & -- & 1 & -- & -. & 21 & -- & 73 \\
\hline Cottonwood & 7 & -- & -- & -- & 3 & -- & -- & 4 \\
\hline Willow & 82 & -- & -- & -. & - & 33 & -- & 49 \\
\hline Hackberry & -- & -- & -- & -- & -- & -- & -. & $\ldots$ \\
\hline Balsam poplar & 15 & - & -- & -- & -- & - & - & 15 \\
\hline Bigtooth aspen & 2,105 & 7 & 258 & 27 & -- & 37 & -- & 1,776 \\
\hline Quaking aspen & 7,945 & -- & 1,412 & 59 & 14 & 560 & 52 & 5,848 \\
\hline Paper birch & 817 & -- & 190 & 11 & - & 12 & - & 604 \\
\hline River birch & 139 & - & 41 & - & -- & -- & -- & 98 \\
\hline Black cherry & 155 & -- & 91 & -- & -- & 13 & -- & 51 \\
\hline Black walnut & -- & -- & -- & -- & - & -- & -- & -- \\
\hline Butternut & 59 & -. & -- & -- & -- & -- & - & 59 \\
\hline Other hardwoods & 23 & -- & 2 & -- & -- & -- & -- & 21 \\
\hline Total & 21,298 & 209 & 3,498 & 142 & 35 & 1,020 & 93 & 16,301 \\
\hline All species & 24,166 & 238 & 3,672 & 380 & 45 & 1,384 & 124 & 18,323 \\
\hline
\end{tabular}


Table 57.--Annual mortality of sawtimber on commercial forest land by species group and cause, Central Unit, Wisconsin, 1982

(In thousand board feet) 1 /

\begin{tabular}{|c|c|c|c|c|c|c|c|c|}
\hline \multirow[b]{2}{*}{ Species group } & \multirow[b]{2}{*}{$\begin{array}{c}\text { All } \\
\text { causes }\end{array}$} & \multicolumn{7}{|c|}{ Cause } \\
\hline & & Insects & Disease & Fire & Animals & Weather & Suppression & $\begin{array}{l}\text { Unknown } \\
\text { and other }\end{array}$ \\
\hline \multicolumn{9}{|l|}{ Softwoods } \\
\hline Jack pine & 3,292 & 5 & 162 & 254 & - & 560 & 6 & 2,305 \\
\hline Red pine & - & -- & -- & - & -- & - & -- & -- \\
\hline White pine & 1,316 & 11 & 278 & - & -- & -- & 2 & 1,025 \\
\hline White spruce & -- & -- & -- & -- & -- & -- & -- & -- \\
\hline Black spruce & -- & -- & -- & - & -- & -- & -- & -- \\
\hline Balsam fir & 189 & -- & 3 & -- & -- & -- & -- & 186 \\
\hline Hemlock & 665 & -- & 10 & - & 24 & 150 & -- & 481 \\
\hline Tamarack & 416 & -- & -- & - & - & 238 & -- & 178 \\
\hline Eastern redcedar & -- & -- & -- & -- & -- & -- & -- & -- \\
\hline Northern white-cedar & 36 & 5 & -- & -- & 5 & 5 & -- & 21 \\
\hline Other softwoods & 4 & -- & -- & -. & -- & -- & -- & 4 \\
\hline Total & 5,918 & 21 & 453 & 254 & 29 & 953 & 8 & 4,200 \\
\hline \multicolumn{9}{|l|}{ Hardwoods } \\
\hline White oak & 992 & -- & 23 & -- & 13 & 23 & .. & 933 \\
\hline Select red oak & 3,855 & -- & 463 & -- & $\therefore$ & 491 & -- & 2,901 \\
\hline Other red oak & 3,094 & -- & 286 & -- & -- & 515 & -- & 2,293 \\
\hline Select hickory & 9 & -. & 4 & -- & -- & -- & -- & 5 \\
\hline Other hickory & 4 & -- & -- & - & -- & - & -. & 4 \\
\hline Basswood & 888 & -- & -- & - & -- & 86 & -- & 802 \\
\hline Beech & 31 & -- & -- & -- & -- & -- & -- & 31 \\
\hline Yellow birch & 439 & -- & 9 & - & -- & - & -- & 430 \\
\hline Hard maple & 971 & -- & 32 & - & 4 & 9 & 76 & 850 \\
\hline Soft maple & 1,445 & -- & 140 & -- & 10 & 11 & -- & 1,284 \\
\hline Elm & 13,587 & 510 & 11,618 & - & 28 & $\ldots$ & -- & 1,431 \\
\hline Black ash & 175 & -- & -- & -- & -- & -- & -- & 175 \\
\hline White \& green ash & 163 & -- & 6 & -- & -- & 66 & -- & 91 \\
\hline Cottonwood & 35 & -- & -- & - & 15 & - & -- & 20 \\
\hline Willow & 326 & -- & -- & -- & - & 135 & -- & 191 \\
\hline Hackberry & -- & -- & -- & -- & -- & -- & -- & -- \\
\hline Balsam poplar & -- & -- & -- & - & -- & -- & -- & -- \\
\hline Bigtooth aspen & 2,808 & 30 & 278 & - & -- & 159 & -- & 2,341 \\
\hline Quaking aspen & 4,480 & -- & 1,202 & -- & -- & 250 & -- & 3,028 \\
\hline Paper birch & 234 & -- & 2 & -- & -- & $\ldots$ & -- & 232 \\
\hline River birch & 259 & -- & - & -- & -- & -- & -- & 259 \\
\hline Black cherry & 79 & -- & -- & -- & -- & 61 & -- & 18 \\
\hline Black walnut & -- & -- & -- & - & -- & -- & -- & -- \\
\hline Butternut & 245 & -- & -- & -- & - & -- & -- & 245 \\
\hline Other hardwoods & 14 & - & $\ldots$ & -- & - & -- & -- & 14 \\
\hline Total & 34,133 & 540 & 14,063 & $\ldots$ & 70 & 1,806 & 76 & 17,578 \\
\hline All species & 40,051 & 561 & 14,516 & 254 & 99 & 2,759 & 84 & 21,778 \\
\hline
\end{tabular}

$1 /$ International $1 / 4$-inch rule. 
Table 58.--Annual mortality of growing stock and sawtimber on commercial forest land by county and softwoods and hardwoods, Central Unit, Wisconsin, 1982

\begin{tabular}{|c|c|c|c|c|c|c|}
\hline \multirow[b]{2}{*}{ County } & \multicolumn{3}{|c|}{ Growing stock } & \multicolumn{3}{|c|}{ Sawtimber } \\
\hline & $\begin{array}{c}\text { All } \\
\text { species }\end{array}$ & Softwoods & Hardwoods & $\begin{array}{c}\text { All } \\
\text { species }\end{array}$ & Softwoods & Hardwoods \\
\hline & - - - & us and cubic & et $\cdots$ & $\ldots-1$ & sand board & $\mathrm{t} 11 \ldots$ \\
\hline Adams & 1,089 & 350 & 739 & 1,966 & 916 & 1,050 \\
\hline Chippewa & 2,028 & 117 & 1,911 & 3,543 & 253 & 3,290 \\
\hline Clark & 3,238 & 66 & 3,172 & 4,104 & 341 & 3,763 \\
\hline Eau Claire & 1,273 & 87 & 1,186 & 1,593 & 96 & 1,497 \\
\hline Jackson & 2,501 & 372 & 2,129 & 3,520 & 641 & 2,879 \\
\hline Juneau & 1,991 & 440 & 1,551 & 3,667 & 901 & 2,766 \\
\hline Marathon & 4,049 & 315 & 3,734 & 7,515 & 544 & 6,971 \\
\hline Marquette & 316 & 77 & 239 & 768 & 26 & 742 \\
\hline Monroe & 1,409 & 248 & 1,161 & 3,214 & 680 & 2,534 \\
\hline Portage & 1,468 & 156 & 1,312 & 2,144 & 242 & 1,902 \\
\hline Waupaca & 2,163 & 299 & 1,864 & 5,022 & 601 & 4,421 \\
\hline Waushara & 725 & 212 & 513 & 938 & 395 & 543 \\
\hline Wood & 1,916 & 129 & 1,787 & 2,057 & 282 & 1,775 \\
\hline All counties & 24,166 & 2,868 & 21,298 & 40,051 & 5,918 & 34,133 \\
\hline
\end{tabular}

1/International $1 / 4$-inch rule.

Table 59.--Annual mortality of growing stock and sawtimber on commercial forest land by ownership class and softwoods and hardwoods, Central Unit, Wisconsin, 1982

\begin{tabular}{|c|c|c|c|c|c|c|}
\hline \multirow[b]{2}{*}{ Ownership class } & \multicolumn{3}{|c|}{ Growing stock } & \multicolumn{3}{|c|}{ Sawt imber } \\
\hline & $\begin{array}{c}\text { All } \\
\text { species }\end{array}$ & Softwoods & Hardwoods & $\begin{array}{c}\text { All } \\
\text { species } \\
\end{array}$ & Softwoods & Hardwoods \\
\hline & - - - & usand cubic & et $-\cdots$ & -- & sand board & $t \underline{1 /} \cdots$ \\
\hline National Forest & -- & -- & -- & -- & -- & -- \\
\hline Miscell aneous federal & 644 & 168 & 476 & 928 & 473 & 455 \\
\hline State & 576 & 153 & 423 & 701 & 446 & 255 \\
\hline County and municipal & 3,784 & 299 & 3,485 & 2,492 & 362 & 2,130 \\
\hline Indian & 27 & -- & 27 & -- & - & - \\
\hline Forest industry & 1,303 & 125 & 1,178 & 1,874 & 251 & 1,623 \\
\hline Farmer & 8,399 & 1,010 & 7,389 & 17,752 & 1,697 & 16,055 \\
\hline Misc. private-corp. & 1,020 & 90 & 930 & 1,378 & 83 & 1,295 \\
\hline Misc. private-indiv. & 8,413 & 1,023 & 7,390 & 14,926 & 2,606 & 12,320 \\
\hline All owners & 24,166 & 2,868 & 21,298 & 40,051 & 5,918 & 34,133 \\
\hline
\end{tabular}

1/International $1 / 4$-inch rule. 


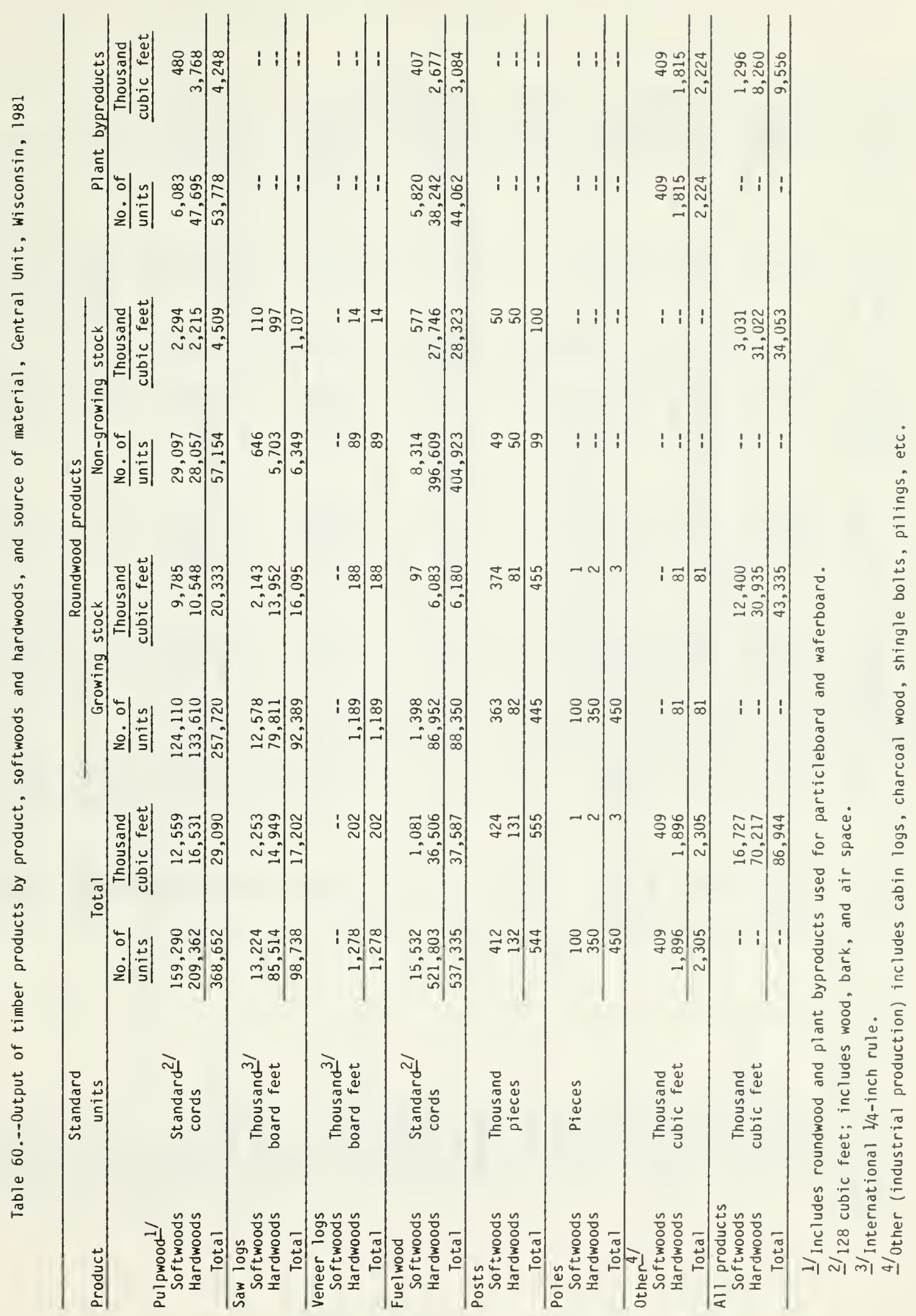




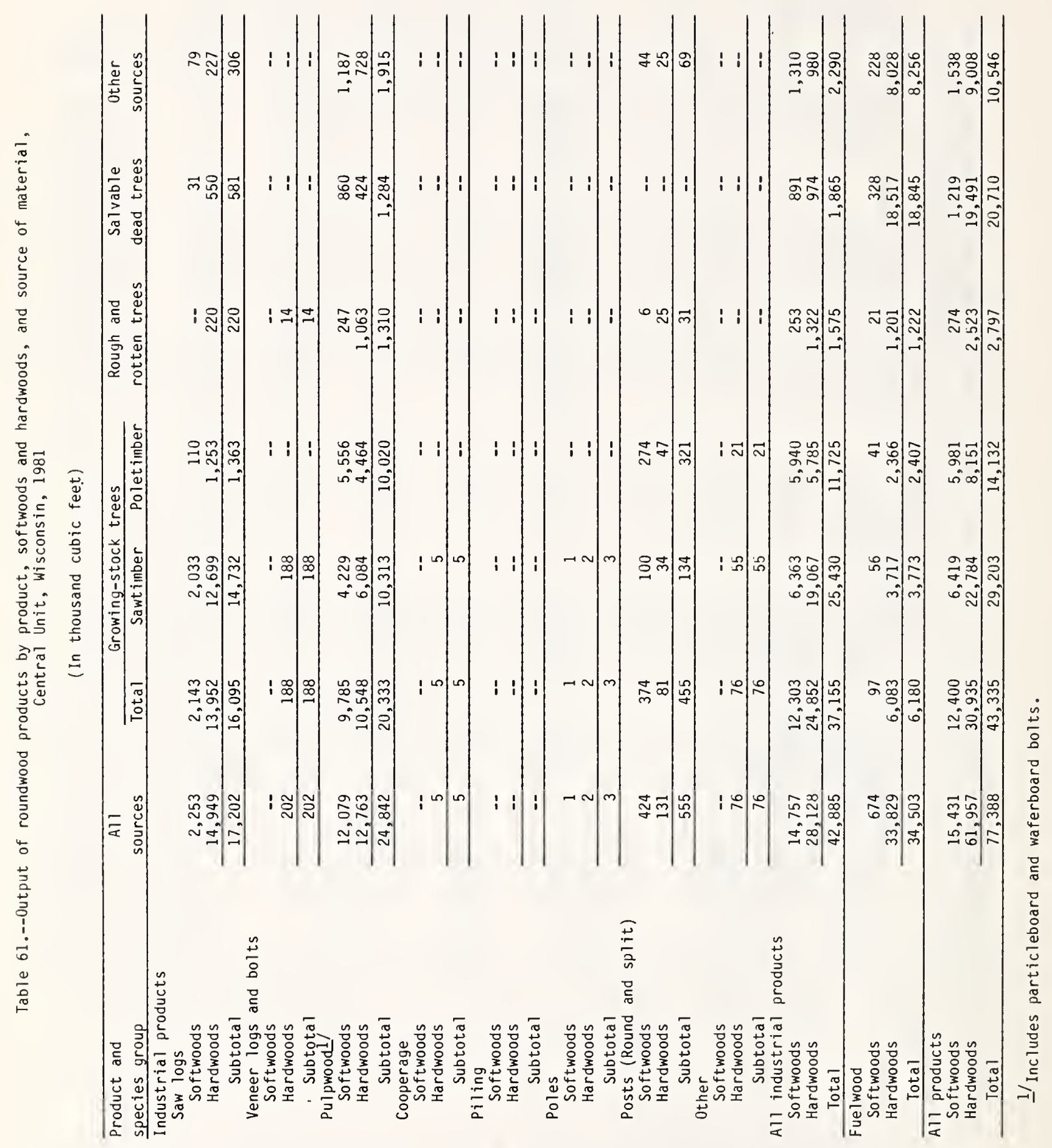


Table 62.--Timber products from roundwood by species group and product, Central Unit, Wisconsin, 1981

\begin{tabular}{|c|c|c|c|c|c|c|c|}
\hline \multirow[t]{3}{*}{ Species group } & \multirow{2}{*}{$\begin{array}{c}\text { All } \\
\text { products } \\
\text { Thousand } \\
\end{array}$} & \multicolumn{2}{|c|}{ Pulpwood $1 /$} & \multicolumn{2}{|c|}{ Saw logs } & \multicolumn{2}{|c|}{ Veneer logs } \\
\hline & & Standard & Thousand & Thous and & Thousand & Thousand & Thousand \\
\hline & cubic feet & cords $2 /$ & cubic feet & board feet- 3 / & cubic feet & board feet 3 - & cubic feet \\
\hline \multicolumn{8}{|l|}{ Softwoods } \\
\hline Jack pine & 6,046 & 71,121 & 5,606 & 167 & 34 & - & -- \\
\hline Red pine & 6,309 & 69,635 & 5,501 & 1,974 & 330 & -. & -- \\
\hline White pine & 2,621 & 9,487 & 749 & 10,053 & 1,706 & -- & -- \\
\hline White spruce & -- & -- & 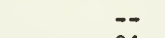 & 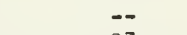 & 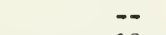 & -- & -- \\
\hline Black spruce & 52 & 479 & 34 & 87 & 18 & -- & -- \\
\hline Balsam fir & 83 & 524 & 40 & 16 & 3 & -- & -- \\
\hline Hemlock & 213 & 1,043 & 79 & 790 & 134 & -- & -- \\
\hline Tamarack & 70 & 918 & 70 & -- & -- & - & -- \\
\hline Northern white-cedar & 37 & -- & -- & 137 & 28 & -- & -- \\
\hline Other softwoods & -- & -- & -- & - & -- & -- & -- \\
\hline Total & 15,431 & 153,207 & 12,079 & 13,224 & 2,253 & -- & -- \\
\hline \multicolumn{8}{|l|}{ Hardwoods } \\
\hline White oak & 6,785 & 11,725 & 926 & 9,815 & 1,719 & 8 & 1 \\
\hline Select red oak & 14,976 & 19,972 & 1,578 & 24,455 & 4,285 & 328 & 53 \\
\hline Other red oak & 8,591 & 11,460 & 905 & 14,032 & 2,458 & 188 & 30 \\
\hline Hickory & 214 & 53 & 3 & 367 & 63 & -- & -- \\
\hline Basswood & 1,023 & 682 & 52 & 5,174 & 921 & 99 & 17 \\
\hline Beech & 36 & 3 & $4 /$ & 203 & 36 & -- & -- \\
\hline Yellow birch & 816 & 2,745 & $21 \overline{5}$ & 497 & 86 & 147 & 21 \\
\hline Hard maple & 3,670 & 7,837 & 619 & 7,277 & 1,214 & 142 & 24 \\
\hline Soft maple & 3,191 & 7,150 & 566 & 4,941 & 881 & 122 & 20 \\
\hline EIm & 6,931 & 7,847 & 619 & 4,481 & 797 & 178 & 27 \\
\hline Ash & 2,372 & 3,441 & 273 & 2,547 & 454 & 12 & 1 \\
\hline Cottonwood & 3 & -- & -- & 24 & 3 & -- & -- \\
\hline Balsam poplar & 2 & -- & -- & 11 & 2 & -- & -- \\
\hline Bigtooth aspen & 3,025 & 22,362 & 1,766 & 3,056 & 532 & 6 & 1 \\
\hline Quaking aspen & 7,742 & 57,220 & 4,518 & 7,820 & 1,363 & 15 & 2 \\
\hline Paper birch & 2,113 & 8,985 & 709 & 570 & 96 & 33 & 5 \\
\hline Black walnut & 2 & - & -- & 24 & 2 & -- & -- \\
\hline Other hardwoods $5 /$ & 465 & 185 & 14 & 220 & 37 & -- & $=-$ \\
\hline Total & 61,957 & 161,667 & 12,763 & 85,514 & 14,949 & 1,278 & 202 \\
\hline All species & 77,388 & 314,874 & 24,842 & 98,738 & 17,202 & 1,278 & 202 \\
\hline
\end{tabular}

1/Includes particleboard and waferboard bolts.

(Table 62 continued on next page)

2/ 128 cubic feet; includes wood, bark, and air space.

$3 /$ International $1 / 4-i n c h$ rule.

4 Less than 500 cubic feet.

5/Includes butternut and black cherry. 
(Table 62 continued)

\begin{tabular}{|c|c|c|c|c|c|c|c|}
\hline \multirow[t]{3}{*}{ Species group } & \multicolumn{2}{|c|}{ Fuelwood } & \multicolumn{2}{|c|}{ Posts } & \multicolumn{2}{|c|}{ Poles } & \multirow{2}{*}{$\begin{array}{l}\begin{array}{c}\text { Other } \\
\text { products }\end{array} \\
\text { Thousand }\end{array}$} \\
\hline & Standard & Thousand & Thousand & Thousand & Pieces & Thous and & \\
\hline & cords 21 & cubic feet & pieces & cubic feet & & $\overline{\text { cubic feet }}$ & cubic feet \\
\hline \multicolumn{8}{|l|}{ Softwoods } \\
\hline Jack pine & 5,852 & 406 & -- & -- & -- & -- & -- \\
\hline Red pine & 787 & 54 & 412 & 424 & -- & -- & -- \\
\hline White pine & 2,380 & 166 & -- & -- & -- & -- & -- \\
\hline White spruce & - & -- & -- & -- & -- & - & -- \\
\hline Black spruce & -- & -- & -- & -- & -- & -- & -- \\
\hline Ballsam fir & 582 & 40 & -- & - & -- & -- & -- \\
\hline Hemlock & -- & -- & -- & -- & -- & -- & -- \\
\hline Tamarack & -- & -- & -- & -- & -- & -- & -- \\
\hline Northern white-cedar & 111 & 8 & -- & -- & 100 & 1 & -- \\
\hline Other sof twoods & - & -- & -- & -- & -- & - & -- \\
\hline Total & 9,712 & 674 & 412 & 424 & 100 & 1 & - \\
\hline \multicolumn{8}{|l|}{ Hardwoods } \\
\hline White oak & 57,983 & 4,058 & 77 & 75 & 150 & 1 & 5 \\
\hline Select red oak & 129,366 & 9,053 & 5 & 6 & 127 & 1 & -- \\
\hline Other red oak & 74,231 & 5,195 & 3 & 3 & 73 & $4 /$ & -- \\
\hline Hickóry & 2,137 & 148 & -- & -- & -- & $=$ & -- \\
\hline 8asswood & 475 & 33 & -- & -- & -- & -- & -- \\
\hline 8eech & -- & -- & -- & -- & -- & $=$ & -- \\
\hline Yellow birch & 7,085 & 494 & -- & -- & -- & -- & -- \\
\hline Hard maple & 25,960 & 1,813 & -- & -- & -- & -- & -- \\
\hline Soft maple & 24,523 & 1,716 & -- & -- & -- & -- & 8 \\
\hline Elm & 78,460 & 5,488 & -- & -- & -- & -- & -- \\
\hline Ash & 23,485 & 1,644 & -- & -- & -- & -- & -- \\
\hline Cottonwood & - & -- & -- & -- & -- & -- & -- \\
\hline Balsam poplar & -- & -- & -- & -- & -- & -- & -- \\
\hline Bigtooth aspen & 10,122 & 708 & 1 & 1 & -- & -- & 17 \\
\hline Quaking aspen & 25,901 & 1,811 & 4 & 4 & -- & -- & 44 \\
\hline Paper birch & 18,553 & 1,300 & -- & -- & -- & -- & 3 \\
\hline 81 ack walnut & -- & -- & -- & -- & -- & -- & -- \\
\hline 0ther hardwoods - & 5,280 & 368 & 42 & 42 & -- & -- & 4 \\
\hline Total & 483,561 & 33,829 & 132 & 131 & 350 & 2 & 81 \\
\hline All species & 493,273 & 34,503 & 544 & 555 & 450 & 3 & 81 \\
\hline
\end{tabular}

2/128 cubic feet; includes wood, bark, and air space.

4/ Less than 500 cubic feet.

$\underline{5}$ Includes butternut and black cherry.

Table 63.--Volume of primary plant residue by use and type of residue, Central Unit, Wisconsin, 1981

(In thousand cubic feet)

\begin{tabular}{|c|c|c|c|c|c|c|c|c|}
\hline \multirow[b]{3}{*}{ Use } & \multicolumn{6}{|c|}{ Wood residue } & & \\
\hline & \multicolumn{2}{|c|}{ Total } & \multicolumn{2}{|c|}{ Coarsel/ } & \multicolumn{2}{|c|}{ Fine $^{2 /}$} & \multicolumn{2}{|c|}{$8 a r k-3 /$} \\
\hline & Softwoods & Hardwoods & Softwoods & Hardwoods & Softwoods & Hardwoods & Softwoods & Hardwoods \\
\hline Fiber products $\underline{4}$ & 312.3 & $2,755.4$ & 277.0 & $2,408.0$ & 35.3 & 347.4 & -- & -- \\
\hline Charcoal & 0.9 & 20.7 & -- & -- & 0.9 & 20.7 & -- & -- \\
\hline Industrial fuel & 99.7 & 999.9 & 70.4 & 317.4 & 29.3 & 682.5 & 114.1 & $1,482.3$ \\
\hline Domestic fuel & 307.7 & $1,677.0$ & 306.4 & $1,589.0$ & 1.3 & 88.0 & 144.2 & 646.5 \\
\hline Miscellaneous $\underline{5}$ & 408.2 & $1,794.1$ & 72.7 & 255.4 & 335.5 & $1,538.7$ & 175.7 & 789.8 \\
\hline Not used-6/ & 31.8 & 241.6 & 6.7 & 92.2 & 25.1 & 149.4 & 32.4 & 164.5 \\
\hline Total & $1,160.6$ & $7,488.7$ & 733.2 & $4,662.0$ & 427.4 & $2,826.7$ & 466.4 & $3,083.1$ \\
\hline
\end{tabular}

1/Suitable for chipping such as slabs, edgings, veneer cores, etc.

2/Not suitable for chipping such as sawdust, veneer clippings, etc.

$3 /$ Does not include bark disposal at pulpmills.

4/For manufacture of pulp, hardboard, or roofing felt.

5/Livestock bedding, mulch, small dimension, and specialty items.

6/Includes residue burned as waste. 


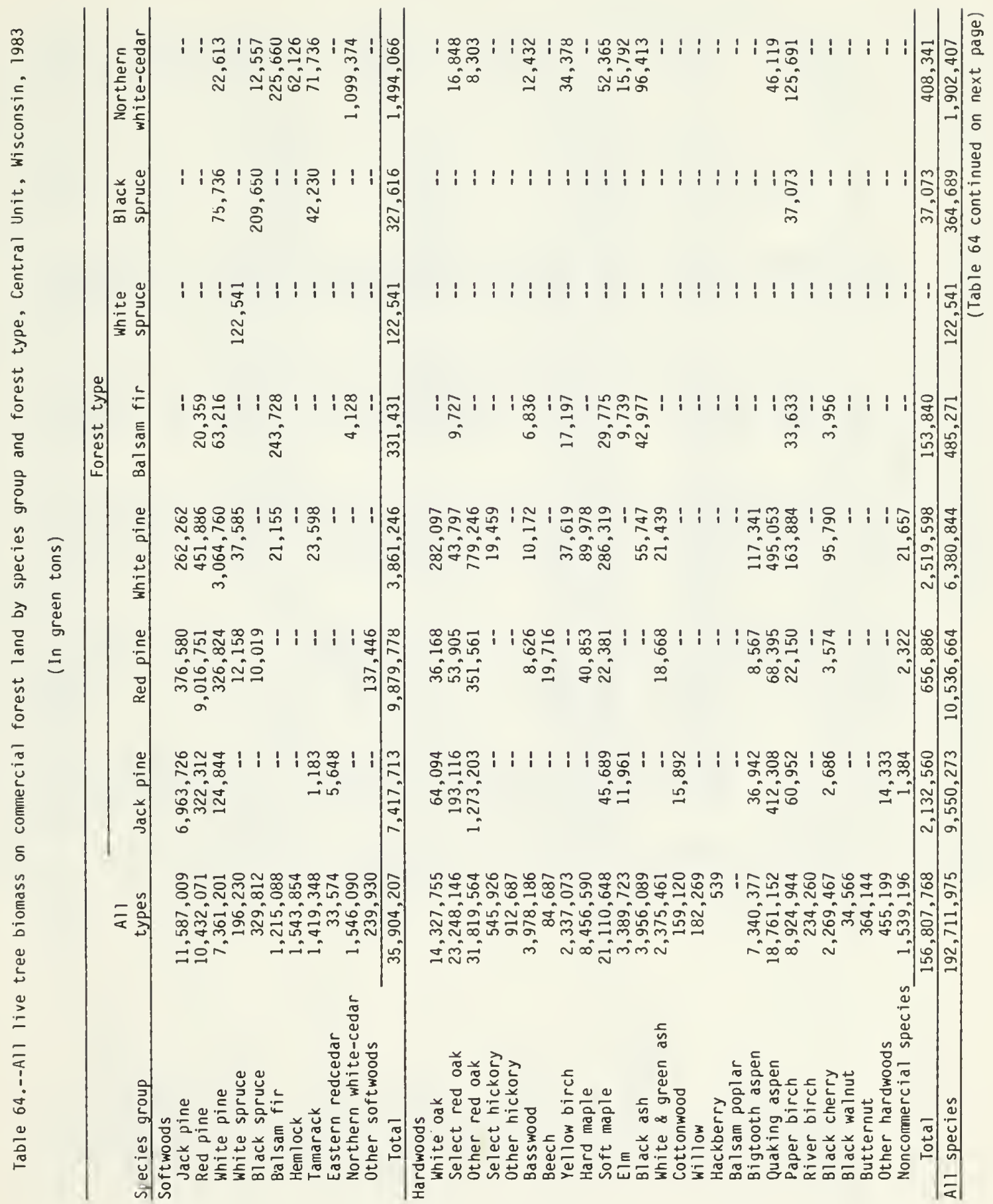




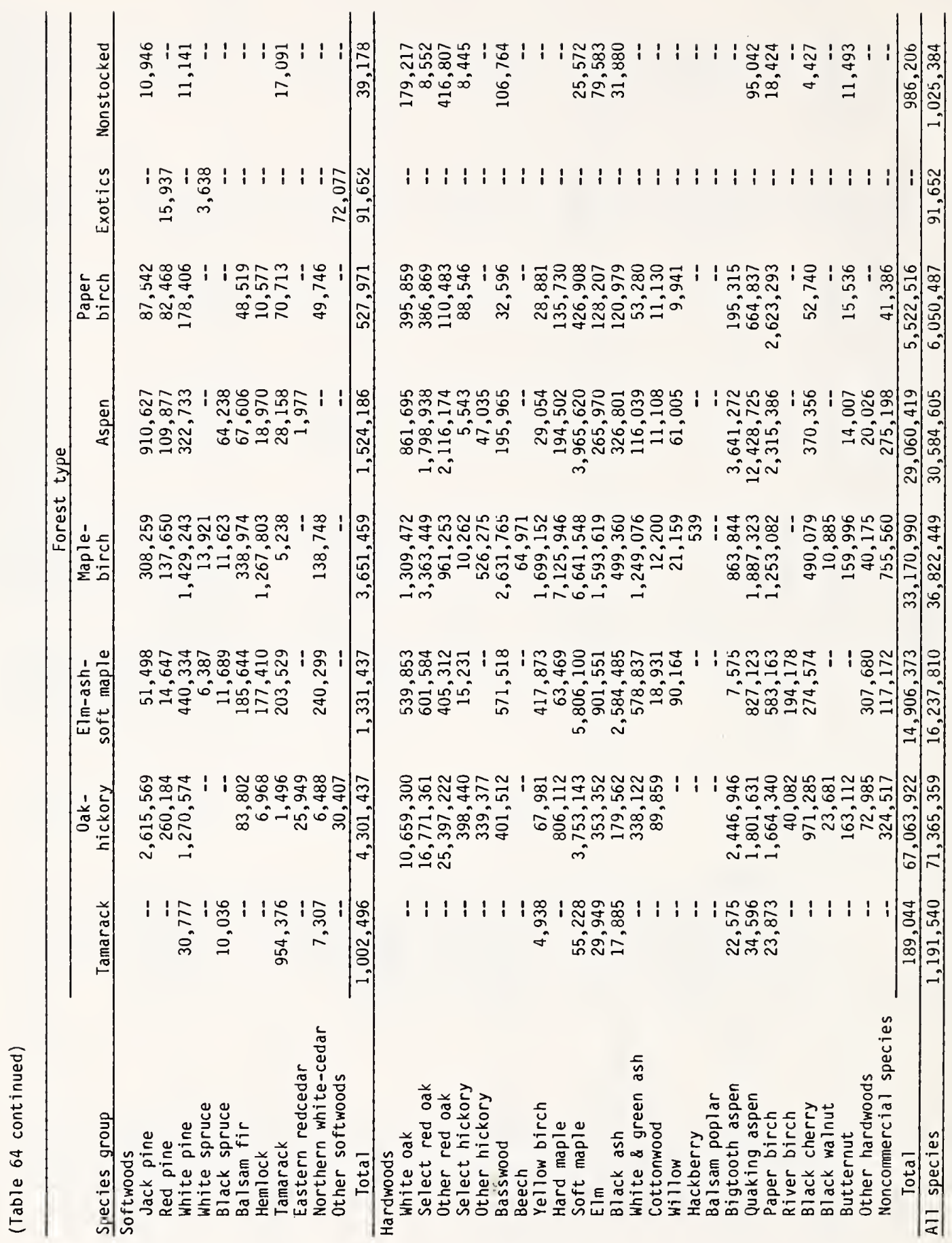


Table 65.--All live tree biomass by species group and tree biomass component, Central Unit, Wisconsin, 1983

(In green tons)

\begin{tabular}{|c|c|c|c|c|c|c|}
\hline \multirow[b]{3}{*}{ Species group } & \multirow[b]{3}{*}{$\begin{array}{c}\text { All } \\
\text { components }\end{array}$} & \multicolumn{5}{|c|}{ Biomass component } \\
\hline & & \multirow{2}{*}{$\begin{array}{l}\text { All live } \\
1 \text { - to } 5 \text {-inch } \\
\text { trees }\end{array}$} & \multicolumn{2}{|c|}{ Growing stock } & \multicolumn{2}{|c|}{$\mathrm{Cu} 11$} \\
\hline & & & Boles & $\begin{array}{c}\text { Tops and } \\
\text { limbs }\end{array}$ & Boles & $\begin{array}{c}\text { Tops and } \\
\text { limbs }\end{array}$ \\
\hline \multicolumn{7}{|l|}{ Softwoods } \\
\hline Jack pine & $11,587,009$ & $1,982,679$ & $6,081,618$ & $2,590,866$ & 672,134 & 259,712 \\
\hline Red pine & $10,432,071$ & $1,273,115$ & $6,304,958$ & $2,711,601$ & 104,116 & 38,281 \\
\hline White pine & $7,361,201$ & 737,781 & $4,184,850$ & $1,796,349$ & 450,001 & 192,220 \\
\hline White spruce & 196,230 & 167,568 & 20,310 & 8,352 & - & - \\
\hline Black spruce & 329,812 & 212,764 & 82,811 & 34,237 & -- & -- \\
\hline Balsam fir & $1,215,088$ & 489,853 & 472,136 & 193,610 & 41,814 & 17,675 \\
\hline Henilock & $1,543,854$ & 50,486 & 904,213 & 379,748 & 147,061 & 62,346 \\
\hline Tamarack & $1,419,348$ & 323,892 & 738,559 & 310,526 & 32,613 & 13,758 \\
\hline Eastern redcedar & 33,574 & 13,702 & 7,660 & 3,152 & 6,409 & 2,651 \\
\hline Northern white-cedar & $1,546,090$ & 586,164 & 591,444 & 240,062 & 93,895 & 34,525 \\
\hline Other softwoods & 239,930 & 81,521 & 74,595 & 30,919 & 41,404 & 11,491 \\
\hline Total & $35,904,207$ & $5,919,525$ & $19,463,154$ & $8,299,422$ & $1,589,447$ & 632,659 \\
\hline \multicolumn{7}{|l|}{ Hardwoods } \\
\hline White oak & $14,327,755$ & 997,625 & $6,610,259$ & $2,742,134$ & $2,872,288$ & $1,105,449$ \\
\hline Select red oak & $23,248,146$ & 412,988 & $13,333,723$ & $5,666,592$ & $2,695,845$ & $1,138,998$ \\
\hline Other red oak & $31,819,564$ & $1,627,874$ & $13,106,278$ & $5,490,472$ & $8,234,946$ & $3,359,994$ \\
\hline Select hickory & 545,926 & 72,849 & 215,953 & 91,659 & 121,884 & 43,581 \\
\hline Other hickory & 912,687 & 148,283 & 482,205 & 204,629 & 54,454 & 23,116 \\
\hline Basswood & $3,978,186$ & 307,728 & $2,206,065$ & 937,968 & 375,397 & 151,028 \\
\hline Beech & 84,687 & - & 36,015 & 15,288 & 23,401 & 9,983 \\
\hline Yellow birch & $2,337,073$ & 235,283 & 936,054 & 390,388 & 550,591 & 224,757 \\
\hline Hard maple & $8,456,590$ & 679,544 & $4,170,069$ & $1,773,228$ & $1,304,202$ & 529,547 \\
\hline Soft maple & $21,110,648$ & $3,880,047$ & $9,504,424$ & $4,046,447$ & $2,682,790$ & 996,940 \\
\hline Elm & $3,389,723$ & 566,977 & $1,561,423$ & 644,361 & 457,122 & 159,840 \\
\hline Black ash & $3,956,089$ & 584,061 & $2,085,964$ & 872,854 & 317,076 & 96,134 \\
\hline White $\&$ green ash & $2,375,461$ & 226,736 & $1,228,914$ & 523,093 & 278,135 & 118,583 \\
\hline Cottonwood & 159,120 & -- & 80,745 & 34,271 & 30,979 & 13,125 \\
\hline Willow & 182,269 & 8,428 & 105,454 & 44,537 & 16,708 & 7,142 \\
\hline Hackberry & 539 & 539 & - & -- & $=-$ & -- \\
\hline Balsam poplar & - & - & $-\infty$ & - & -- & -- \\
\hline Bigtooth aspen & $7,340,377$ & 643,172 & $4,356,953$ & $1,890,685$ & 314,545 & 135,022 \\
\hline Quaking aspen & $18,761,152$ & $2,731,446$ & $9,925,964$ & $4,263,834$ & $1,358,506$ & 481,402 \\
\hline Paper birch & $8,924,944$ & $1,997,665$ & $3,995,727$ & $1,699,051$ & 908,863 & 323,638 \\
\hline River birch & 234,260 & 28,450 & 84,966 & 36,193 & 59,423 & 25,228 \\
\hline Black cherry & $2,269,467$ & 549,401 & 573,084 & 243,994 & 714,376 & 188,612 \\
\hline Black walnut & 34,566 & -- & 7,642 & 3,243 & 16,580 & 7,101 \\
\hline Butternut & 364,144 & 1,215 & 168,244 & 71,889 & 86,121 & 36,675 \\
\hline Other hardwoods & 455,199 & 85,870 & 127,447 & 53,257 & 139,082 & 49,543 \\
\hline Noncommercial species & $1,539,196$ & -- & - & -- & $1,422,406$ & 116,790 \\
\hline Total & $156,807,768$ & $15,786,181$ & $74,903,572$ & $31,740,067$ & $25,035,720$ & $9,342,228$ \\
\hline All species & $192,711,975$ & $21,705,706$ & $94,366,726$ & $40,039,489$ & $26,625,167$ & $9,974,887$ \\
\hline
\end{tabular}


Table 66.--Sampling errors/ for estimates smaller than the Unit totals of volume, net growth, removals, and area of commercial forest land, Central Unit, Wisconsin, 1983

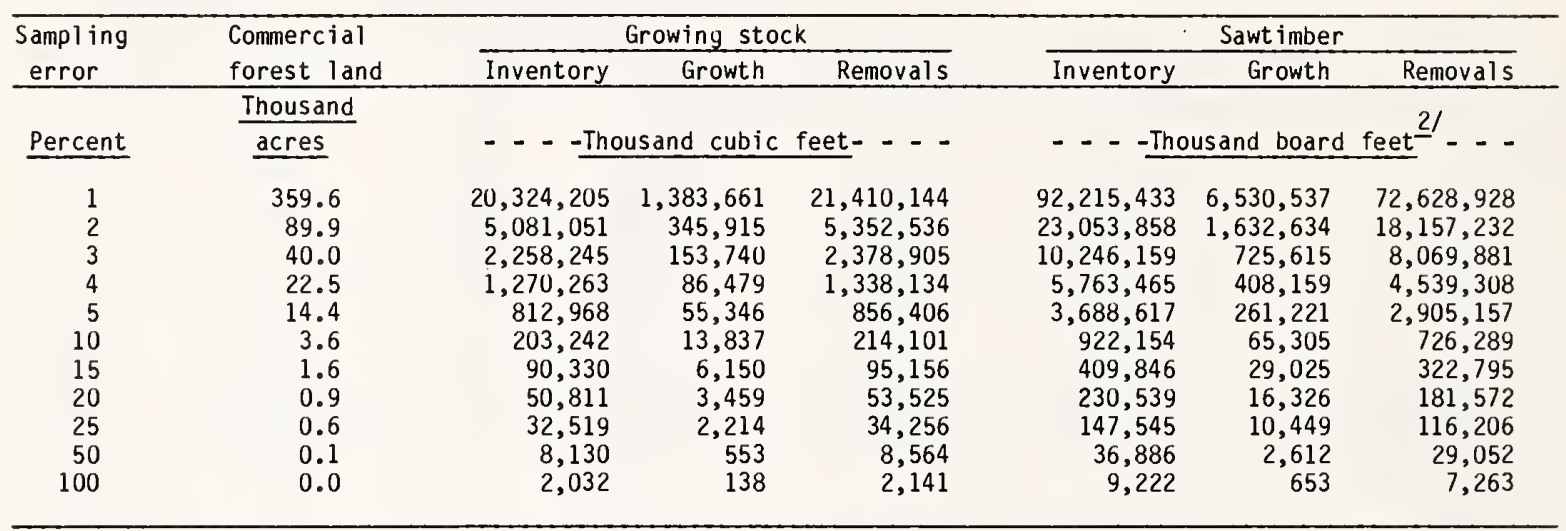

$1 /$ At the 68-percent probability level.

2/International $1 / 4$-inch rule.

Table 67.--Sampling errors for county totals of growing-stock volume, net growth, removals, and area of commercial forest land, Central Unit, Wisconsin, 1983

(Percent of estimate)

\begin{tabular}{|c|c|c|c|c|}
\hline \multirow[b]{2}{*}{ County } & \multirow{2}{*}{$\begin{array}{l}\text { Commercial } \\
\text { forest land }\end{array}$} & \multicolumn{3}{|c|}{ Growing stock } \\
\hline & & Inventory & Growth & Removals \\
\hline $\begin{array}{l}\text { Adams } \\
\text { Chippewa } \\
\text { Clark } \\
\text { Eau Claire } \\
\text { Jackson } \\
\text { Juneau } \\
\text { Marathon } \\
\text { Marquette } \\
\text { Monroe } \\
\text { Portage } \\
\text { Waupaca } \\
\text { Waushara } \\
\text { Wood }\end{array}$ & $\begin{array}{l}1.24 \\
1.26 \\
1.07 \\
1.53 \\
0.98 \\
1.19 \\
1.00 \\
1.95 \\
1.21 \\
1.44 \\
1.44 \\
1.57 \\
1.32\end{array}$ & $\begin{array}{r}11.30 \\
9.80 \\
8.09 \\
11.19 \\
7.86 \\
9.77 \\
7.29 \\
17.93 \\
10.39 \\
11.12 \\
9.17 \\
11.66 \\
10.69\end{array}$ & $\begin{array}{l}13.79 \\
14.15 \\
11.09 \\
15.22 \\
10.50 \\
13.02 \\
10.33 \\
23.53 \\
15.42 \\
14.77 \\
14.15 \\
15.39 \\
14.00\end{array}$ & $\begin{array}{r}103.62 \\
75.33 \\
71.66 \\
133.33 \\
142.12 \\
140.46 \\
49.92 \\
165.14 \\
151.34 \\
123.44 \\
101.28 \\
348.21 \\
82.05\end{array}$ \\
\hline All counties & 0.35 & 2.72 & 3.73 & 26.52 \\
\hline
\end{tabular}






Hahn, Jerold T.

Timber resource of Wisconsin's Central Survey Unit, 1983. Resour. Bull. NC-84. St. Paul, MN: U.S. Department of Agriculture, Forest Service, North Central Forest Experiment Station; 1985. 88 p.

The timber resource of the Central Wisconsin Survey Unit increased 4.2 percent in commercial forest area and increased 75 percent in growing-stock volume between 1968 and 1983. Highlights and statistics from the fourth inventory of this unit are presented for area, volume, growth, mortality, removals, utilization, and biomass.

KEY WORDS: Statistics, area, volume, growth, mortality, removals. 
